EFFECTS OF LARGE NEUTRON DOSES AND ELEVATED TEMPERATURE ON TYPE 347 STAINLESS 


\section{LEGAL NOTICE}

This report was prepared as an occount of Government sponsored work. Neither the United States, nor the Commission, nor any person acting on behalf of the Commission:

A. Makes any warranty or representation, expressed or implied, with respect to the accuracy, completeness, or usefulness of the information contained in this report, or that the use of any information, apparatus, method, or process disclosed in this report may not infringe privately owned rights; or

B. Assumes any liabilities with respect to the use of, or for damages resulting from the use of any information, apparatus, method, or process disclosed in this report.

As used in the above, "person acting on behalf of the Commission" includes any employee or contractor of the Commission, or employee of such contractor, to the extent that such employee or contractor of the Commission, or employee of such contractor prepares, disseminates, or provides access to, any information pursuant to his employment or contract with the Commission, or his employment with such contractor.

Printed in USA

Price

$\$ 1.25$

Available from the

Office of Technical Services

U. S. Department of Commerce

Wa shington 25. D. C. 


\section{DISCLAIMER}

This report was prepared as an account of work sponsored by an agency of the United States Government. Neither the United States Government nor any agency Thereof, nor any of their employees, makes any warranty, express or implied, or assumes any legal liability or responsibility for the accuracy, completeness, or usefulness of any information, apparatus, product, or process disclosed, or represents that its use would not infringe privately owned rights. Reference herein to any specific commercial product, process, or service by trade name, trademark, manufacturer, or otherwise does not necessarily constitute or imply its endorsement, recommendation, or favoring by the United States Government or any agency thereof. The views and opinions of authors expressed herein do not necessarily state or reflect those of the United States Government or any agency thereof. 


\section{DISCLAIMER}

Portions of this document may be illegible in electronic image products. Images are produced from the best available original document. 
Report No. BMI-1609

UC-25 Metals, Ceramics, and Materials (TID-4500, 18th Ed.)

Contract No, W-7405-eng-92

EFFECTS OF LARGE NEUTRON DOSES AND

ELEVATED TEMPERATURE ON TYPE 347 STAINLESS

by

William E. Murr

Frederic R. Shober

Robert Lieberman

Ronald F. Dickerson

January 21, 1963

BATTELLE MEMORIAL INSTITUTE $505 \mathrm{King}$ Avenue

Columbus 1, Ohio 


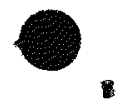

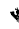

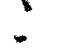

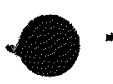




\section{TABLE OF CONTENTS}

$\underline{\text { Page }}$

ABSTRACT • . . . . . . . . . . . . . . . . . . . 1

INTRODUCTION . . . . . . . . . . . . . . . . . . . . . 1

TYPE 347 STAINLESS STEEL SURVEILLANCE PROGRAM - • . • . . . 2

Organization and Status of Program . . . . . . . . . . . . 2

Specimen and Capsule Design . . . . . . . . . . . . . 2

Capsule Irradiation History . . . . . . . . . . . . . . 8

Capsule Dosimetry . . • . . . . . • . . . . . . . . 8

Status of Irradiations . . . . . . . . . . . . . . . . 13

Status of Mechanical-Property Studies . . . . . . . . . . 15

Postirradiation Studies of Surveillance Program Specimens . . . . . 16

Impact Specimens From Capsule BMI-24-14 . . . . . . . . 16

Tensile Tests of Irradiated Specimens . . . . . . . . . . . 19

Metallography and Hardness Studies . . . . . . . . . . . 25

Discussion and Conclusions . . . . . . . . . . . . . . . . . 25

POSTIRRADIATION STUDIES OF SECTIONS OF THE ETR J-10 LOOP • • . 29

Description and History of the J-10 Loop . . . . . . . . . . . 29

Postirradiation Studies of J-10 Specimens . . . . . . . . . . . 31

Sectioning of J-10 Tubes................ . . . . . . 34

Gamma Scan of Loop Strips . . . . . . . . . . . . 34

Dosimetry Results . . . . . . . . . . . . . . . 34

Machining of Tensile Test Specimens. . . . . . . . . . . 41

Tensile Testing Experimental Procedure . . . . . . . . . 41

Metallography and Hardness Testing . . . . . . . . . . . . 43

Discussion and Conclusions . . . . . . . . . . . . . . . 47

REFERENCES • . . . . . . . . . . . . . . . . . . . 50 


\title{
EFFECTS OF LARGE NEUTRON DOSES AND ELEVATED TEMPERATURE ON TYPE 347 STAINLESS
}

\author{
William E. Murr, Frederic R. Shober, Robert Lieberman, \\ and Ronald F. Dickerson
}

\begin{abstract}
Tests of subsize tensile and impact specimens of AISI Type 347 stainless steel irradiated in three capsules to fast-neutron exposures of up to $1.1 \times 10^{22}$ nvt were conducted as part of a continuing eleven-capsule irradiation program involving 144. specimens of this material and fast-neutron exposures from $5 \times 10^{21}$ to greater than $3 \times 10^{22}$ nvt. Ductile fractures at impact energies of $65 \mathrm{ft}-\mathrm{lb}$, representing a 35 per cent decrease in impact strength, were noted at room temperature. Impact energies of only about $20 \mathrm{ft}-\mathrm{lb}$ and a fracture with both brittle and ductile characteristics were observed at $-300 \mathrm{~F}$. Irradiation-induced property changes included increases in yield strength from 35,000 to $105,000 \mathrm{psi}$ and in ultimate strength from 90,000 to $112,000 \mathrm{psi}$ and a decrease in total elongation from 63 to 31 per cent at room temperature. Somewhat lesser changes were noted in specimens tested at $600 \mathrm{~F}$. A $600 \mathrm{~F}$ anneal produced no measurable recovery of preirradiation properties (based upon hardness measurements) for periods up to 144 hr. A large degree of recovery was obtained by annealing $1 \mathrm{hr}$ at $1800 \mathrm{~F}$. Mechanical-property data were also obtained from Type 347 stainless specimens machined from sections of the ETR J-10 pressure loop after fast-flux exposures of up to $7.1 \times 10^{21}$ nvt. Surprisingly, in material irradiated at $750 \mathrm{~F}$, increases in ultimate strength from 92,000 to $149,000 \mathrm{psi}$ and in yield strength from 55,000 to 149,000 psi (60 and 100 per cent, respectively) and decreases in elongation from 55 to 10 per cent and in reductions in area from 70 to 60 per cent were found. Additional tests made at $750 \mathrm{~F}$ showed greater reductions in ductility. Somewhat smaller effects were noted for specimens irradiated at ambient reactor temperatures. Problems associated with nickel dosimetry for fast-flux determinations in the study led to the use of the $F e^{54}(n, p) M n^{54}$ reaction to establish exposures.
\end{abstract}

\section{INTRODUCTION}

Various high-pressure test loops located in the Engineering Test Reactor (ETR) at the National Reactor Testing Station (NRTS) are constructed of AISI Type 347 stainless steel. Because of the great expense, both in time and money, necessary to install and remove such pressure loops in a reactor, it is mandatory that they remain in service as long as possible without becoming operating hazards. Information available in the literature $(1-3)$ indicates that fast-neutron irradiation of stainless steels to exposures of about $3 \times 10^{21}$ to $4 \times 10^{21}$ nvt $(4)$ results in changes in mechanical properties such as increases of about 13 per cent in ultimate tensile strength, increases of 60 per cent in yield strength, and decreases of about 44 per cent in total elongation. Since no data have been published concerning what effect neutron exposures in excess of $4 \times 10^{21} \mathrm{nvt}$ might have on the mechanical properties of stainless steel, the study reported here was undertaken. The program was designed to determine the maximum safe limits of such neutron exposures to this material. The work was initiated by personnel of Knolls Atomic Power Laboratory, who designed and constructed the majority of the capsules and the test specimens. Shortly after the irradiations were initiated, Battelle as sumed responsibility for the program under the direction of the Atomic Energy Commission. Details of the experiments and the initial results obtained from tests of several irradiated specimens are discussed in this report. 
In addition to the work connected with the surveillance program, postirradiation tensile tests were performed on specimens machined from a pressure loop removed from the $J-10$ position of the ETR. This loop, constructed of AISI Type 347 stainless steel, contained a section that operated at process-water temperature and a pressurized section that operated at temperatures up to approximately $750 \mathrm{~F}$. Both sections were irradiated at approximately the same exposure rate and to the same exposure level. Properties of specimens machined from this loop and others, if representative of Type 347 stainless steel in-pile loops, are most important in evaluation of useful in-pile life of reactor components fabricated from this material.

TYPE 347 STAINLESS STEEL SURVEILLANCE PROGRAM

\author{
Organization and Status of Program
}

\title{
Specimen and Capsule Design
}

AISI Type 347 stainless steel in the form of 5/8-in.-diameter rod, annealed and cold finished, meeting the specifications of ASTM A-276-55 with an additional specification that the yield strength should be the 50,000 to 65,000-psi range, was purchased for the test material. The composition of the Type 347 stainless steel employed in the test program is given in Table 1. Table 2 gives the results of tensile tests on the material. KAPL and Battelle preirradiation tensile results obtained from 0.16-in.diameter specimens indicated a "softer" material than the vendor's certification. This difference may be explained by the fact that specimens were machined from a coldfinished rod in which layers of the cold-worked material had been removed to make the smaller specimens, thereby causing lower tensile values.

Specimens were machined from the 5/8-in.-diameter rod by routine machining techniques. Specimen identifications were stamped on the grip ends of the tensile, fatigue, and Charpy impact specimens, and along one side of the Izod specimens. Density measurements were obtained on some of the specimens in each capsule, along with Rockwell hardness measurements to provide a basis for comparison after irradiation exposure.

Two of the 11 capsules included in the surveillance program contained full-size Charpy $\mathrm{V}$-notch and modified subsize Izod specimens. The specimens were arranged in three clusters spaced over the 8-in. capsule length. Each cluster contained two Charpy and four Izod specimens held in place by stainless steel clip holders. Drawings of the two types of impact specimens contained within the two capsules are shown in Figure 1. A view of the impact-capsule specimen train and component capsule parts is shown in Figure 2.

The remaining nine capsules contained subsize buttonhead tensile specimens and cyclic-strain fatigue specimens arranged in three clusters, each cluster containing two tensile and two cyclic-strain fatigue specimens. Drawings of the tensile and cyclicstrain fatigue specimens are shown in Figure 3. A composite view of the capsules containing tensile and fatigue specimens is shown in Figure 4. 
TABLE 1. ANALYSIS OF AISI TYPE 347 STAINLESS STEEL USED FOR IRRADIATION TEST SPECIMENS

\begin{tabular}{|c|c|c|c|c|c|c|c|c|c|}
\hline & \multicolumn{8}{|c|}{ Chemical Analysis, w/o } & \multirow[b]{2}{*}{ Copper } \\
\hline & Garbon & $\begin{array}{l}\text { Man- } \\
\text { ganese }\end{array}$ & $\begin{array}{l}\text { Phos- } \\
\text { phorus }\end{array}$ & Sulfur & Silicon & Nickel & $\begin{array}{l}\text { Chrom- } \\
\text { ium }\end{array}$ & $\begin{array}{l}\text { Tantalum } \\
\text { and } \\
\text { Niobium }\end{array}$ & \\
\hline $\begin{array}{l}\text { Maximum Spe- } \\
\text { cifications }\end{array}$ & 0.08 & 2.00 & 0.030 & 0.030 & 0.75 & $9-13$ & $12-20$ & $<1.00$ & \\
\hline $\begin{array}{l}\text { Analysis by } \\
\text { Manufacturer }\end{array}$ & 0.057 & 1.72 & 0.024 & 0.016 & 0.65 & 10.41 & 17.91 & 0.67 & \\
\hline $\begin{array}{l}\text { Analysis by } \\
\text { KAPL }\end{array}$ & 0.052 & 1.86 & 0.014 & 0.008 & 0.74 & 10.22 & 17.44 & 0.66 & 0.28 \\
\hline
\end{tabular}

TABLE 2. ROOM-TEMPERATURE MECHANICAL PROPERTIES OF AISI T YPE 347 STAINLESS STEEL USED FOR IRRADIATION TEST SPECIMENS

\begin{tabular}{|c|c|c|c|c|c|c|}
\hline Specimen & Tester & $\begin{array}{l}\text { Tensile } \\
\text { Strength. } \\
\text { psi }\end{array}$ & $\begin{array}{c}\text { Yield } \\
\text { Strength } \\
\text { psi }\end{array}$ & $\begin{array}{l}\text { Elongation } \\
\text { per cent in } \\
1.1 \mathrm{in} \text {. }\end{array}$ & $\begin{array}{l}\text { Reduction } \\
\text { in Area } \\
\text { per cent }\end{array}$ & $\begin{array}{l}\text { Rockwell } \\
\text { Hardness }\end{array}$ \\
\hline \multirow{2}{*}{$\begin{array}{l}\text { Standard }(0.505 \\
\text { in. in diameter) }\end{array}$} & Manufacturer & 88,000 & 53,000 & 43.0 & 65.0 & B 92 \\
\hline & KAPL & 91,300 & 56,000 & 63.0 & -. & B $84-87$ \\
\hline \multirow{2}{*}{$\begin{array}{l}\text { Subsize }(0.16 \\
\text { in. in diameter) }\end{array}$} & KAPL & 92,600 & 38,800 & 64.3 & 75.6 & A $48-52$ \\
\hline & $\mathrm{BMI}$ & 89,100 & 35,000 & 61.0 & 73.5 & - \\
\hline
\end{tabular}




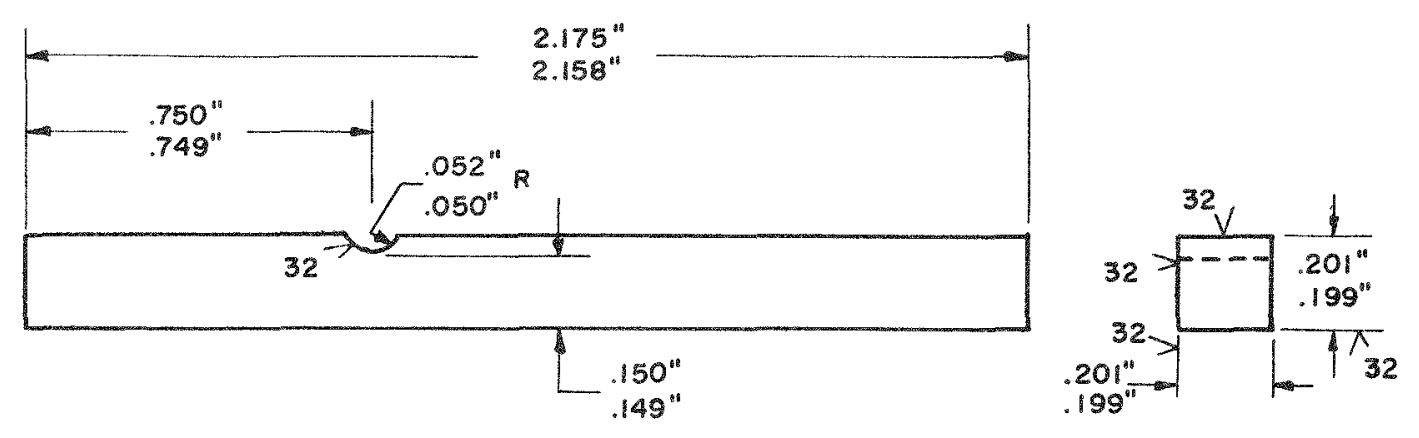

a. Subsize lzod Specimen
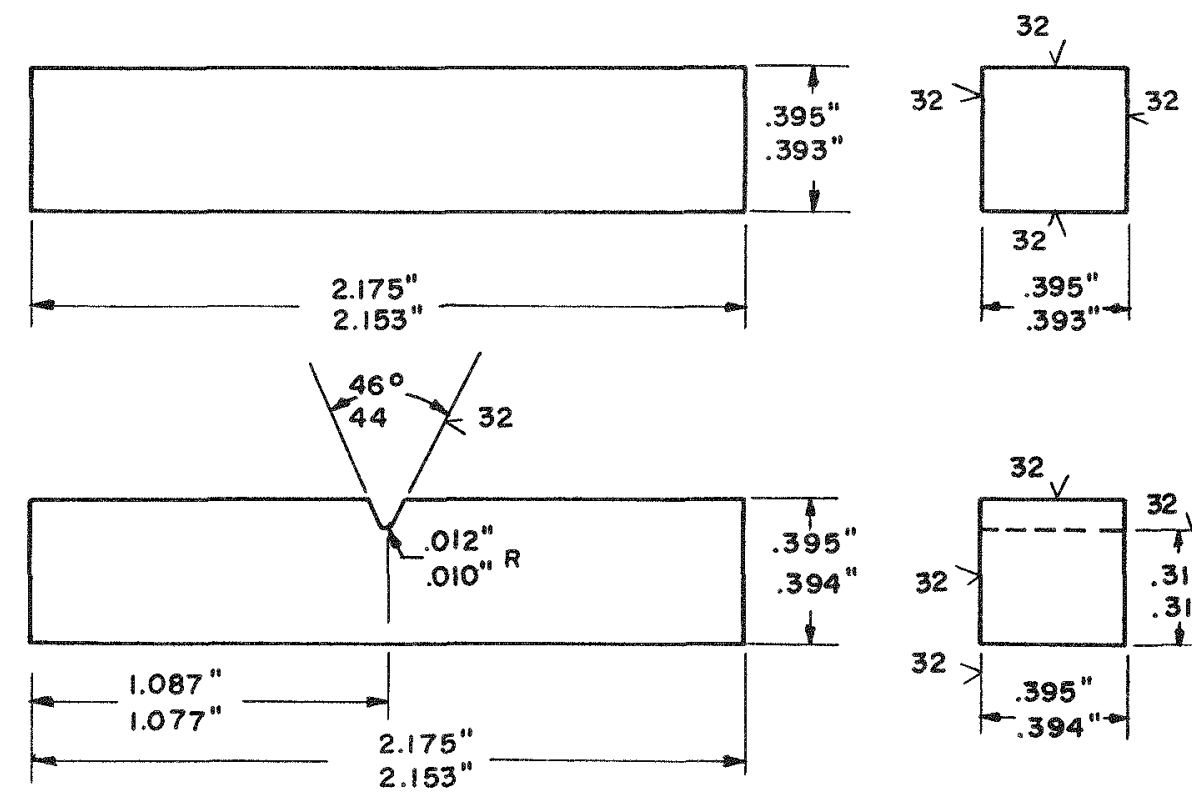

b. Charpy V-Notch Impact Specimen

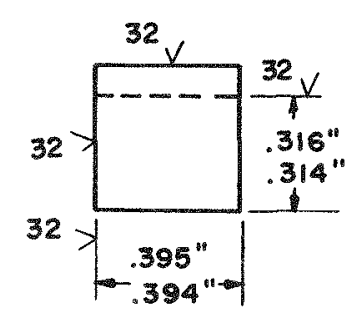

A- 43705

FIGURE 1. DRAWING OF IMPACT SPECIMENS CONTAINED IN CAPSULES BMI-24-4 AND BMI-24- 16

Each of these capsules contained 6 Charpy $V$-notch and 12 subsize Izod specimens. 


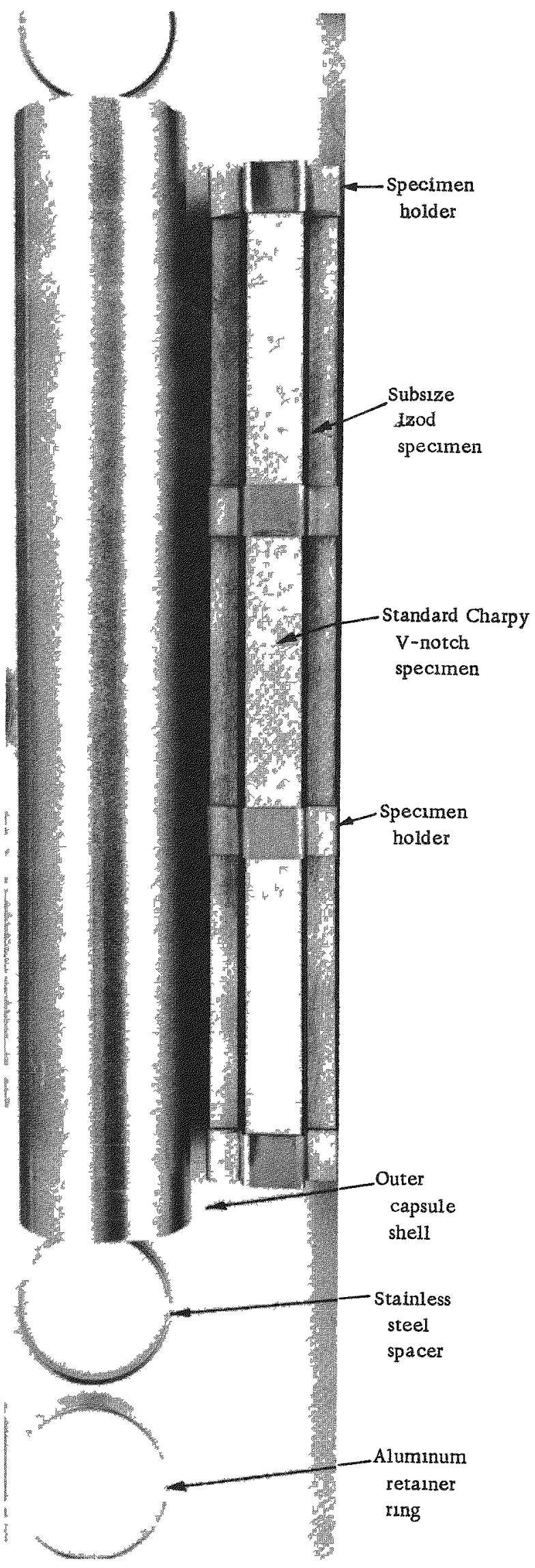

FIGURE 2. VIEW OF CAPSULE AND SPECIMEN

TRAIN FOR CAPSULES BMI-24-14 AND BMI-24-16

These capsules contanned 12 subsize modified Izod specimens and 6 regular-size Charpy specimens 


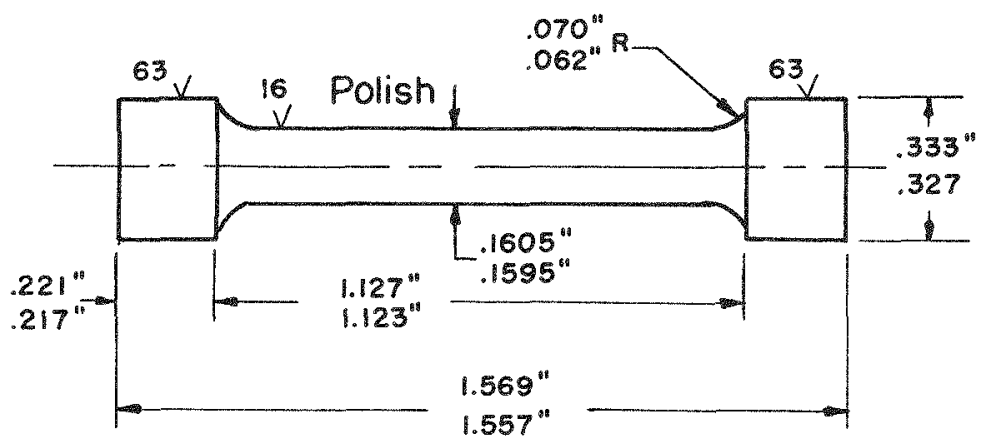

a. Subsize Tensile Specimen

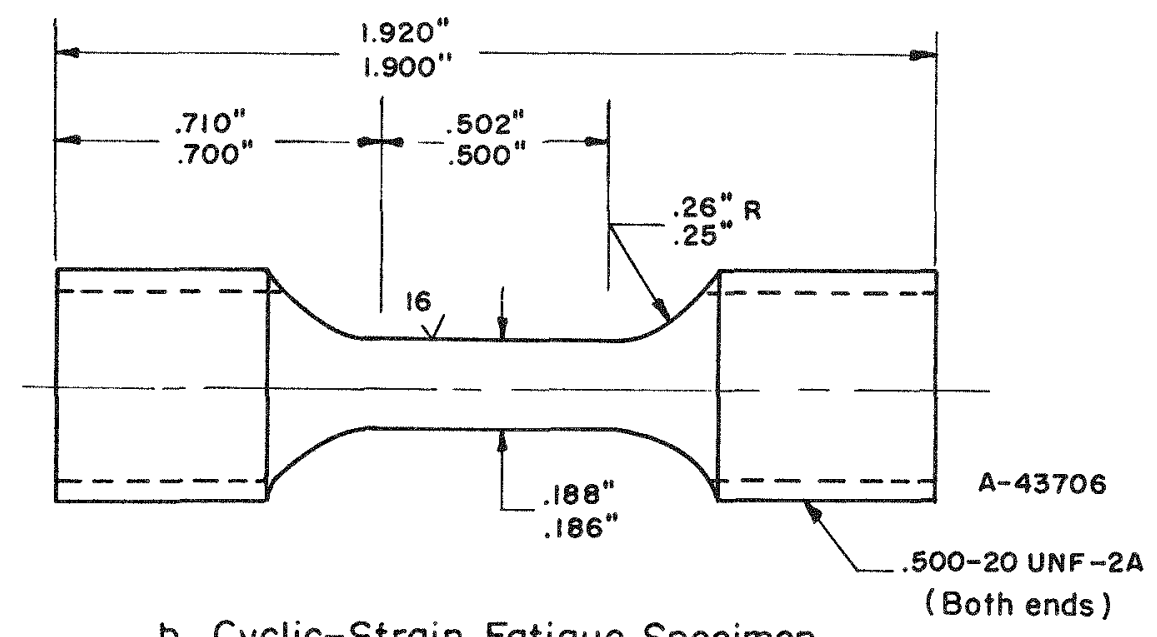

FIGURE 3. DRAWINGS OF SPECIMENS CONTAINED IN CAPSULES BMI-24-2, $-4,-6,-8,-10,-12,-18,-20$ AND -22

Each of these capsules contained six of each type of specimen. 


\section{S.S Spocer \\ L.}

\section{Outer Al}

Shell

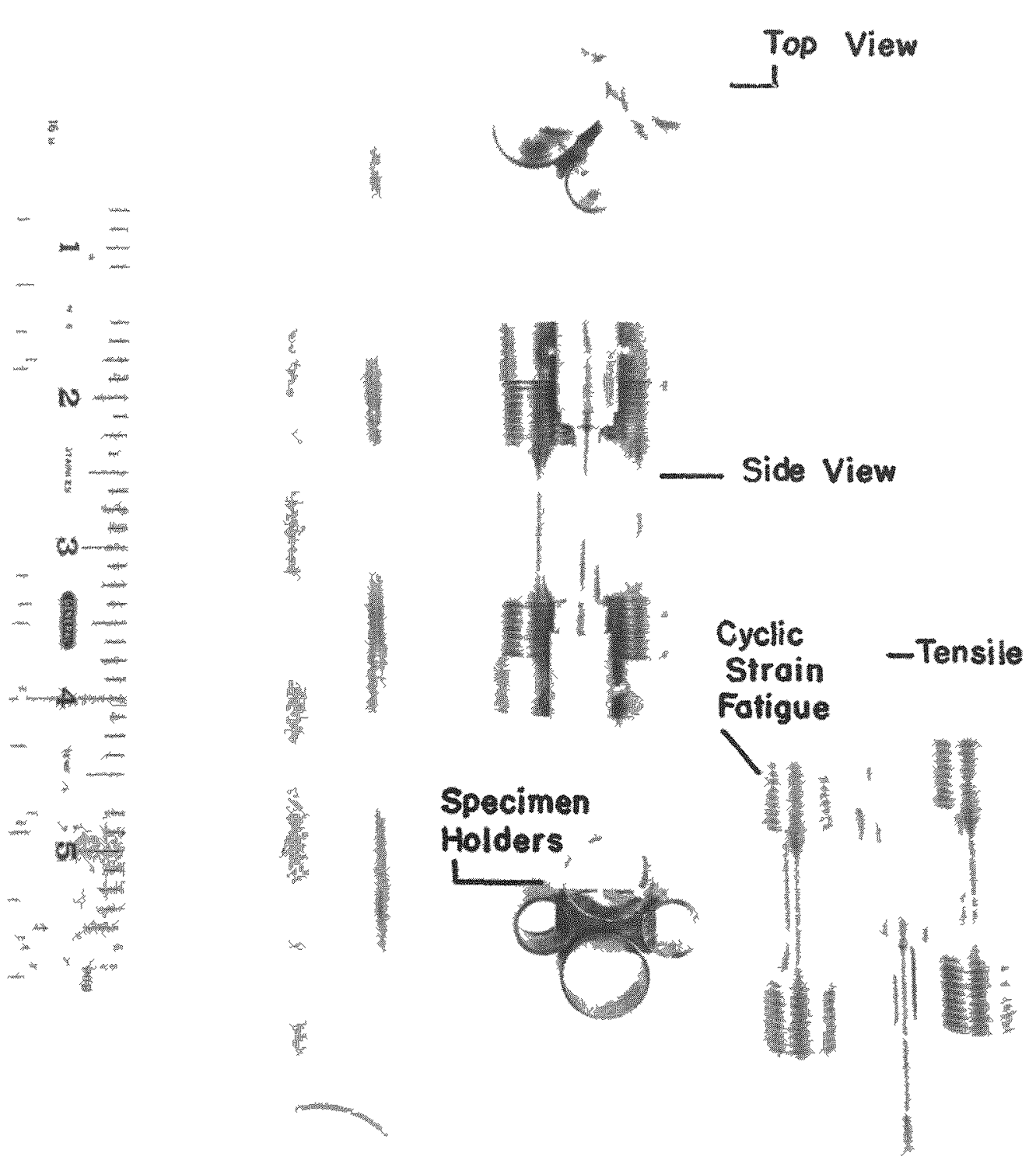

墨

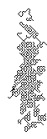
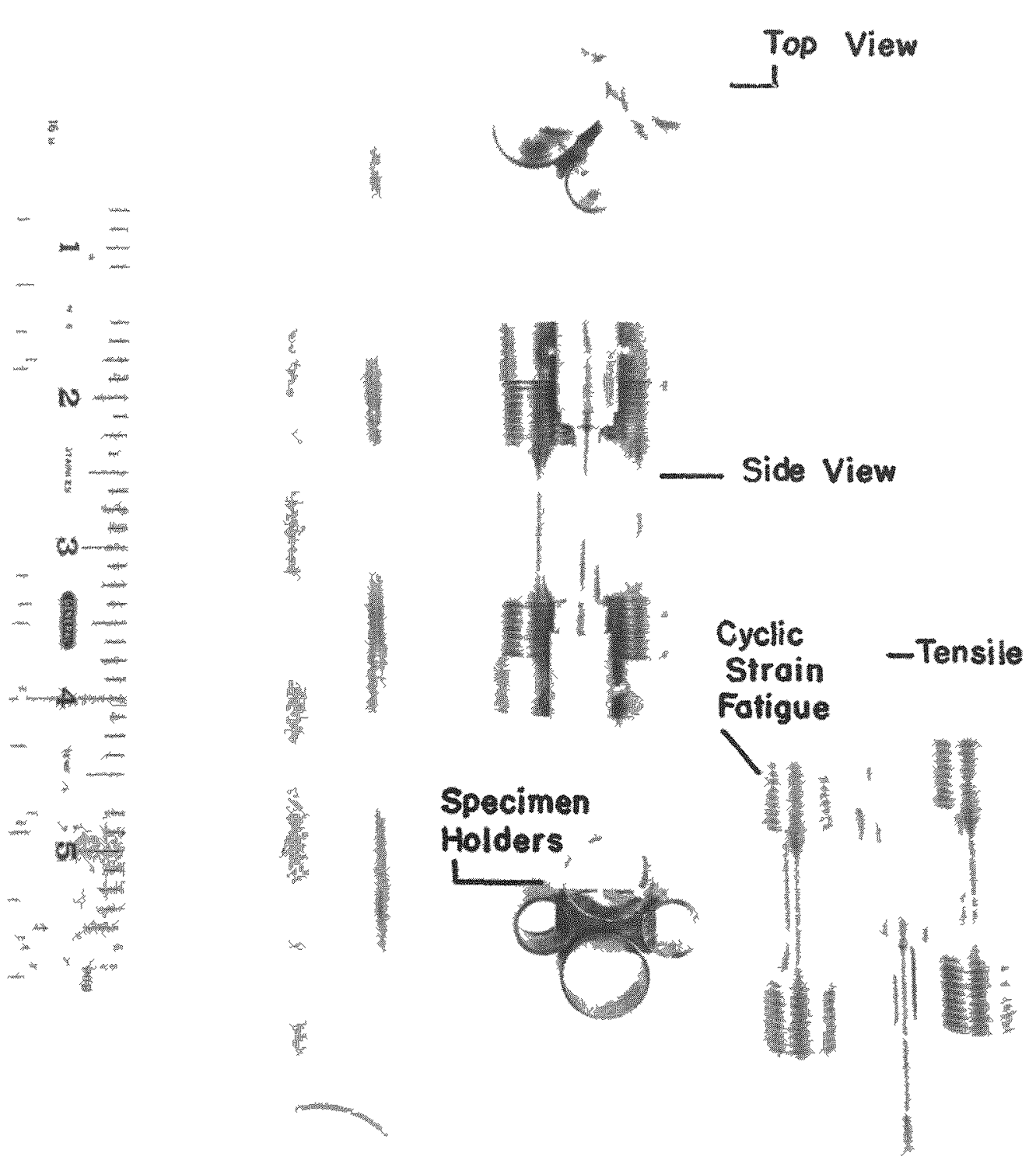

Al Retainer

Ring

N59677

FIGURE 4. TYPE OF CAPSULE USED FOR IRRADIATING SUBSIZE TENSILE AND CYCLIC-STRAIN FATIGUE SPECIMENS The design shown is representative of Capsules BMI-24-2, -4, -6, -8, -10,-12, $-18,-20$, and -22 . 
The specimens wexe encapsulated in open-end Type 304 stainless steel capsules measuring 1.17 in. in diameter by either $7-1 / 4$ or $8 \mathrm{in.}$ long. The open ends permitted reactor process water to contact and flow past the test specimens, thereby providing for removal of the gamma heat produced in the specimens during irradiation. The capsules were positioned in modified X-baskets which were fitted into milled holes in a 3 by $3-i n$. block of 35 aluminum. This aluminum block, or core-filler piece, extended the full length of the active reactor core, and contained holes in the northeast, northwest, southeast, and southwest quadrants to accommodate the capsules. The aluminum core-filler piece also contained 3/8-in.-diameter slots in the north, east, south, and west faces and in the center. These holes were used for the insertion of dosimeter wires for periodic fast-flux monitoring.

\section{Capsule Ir radiation History}

Capsules BMI-24-2, $-4,-6,-8,-10,-12,-14$, and -16 , were loaded into $3 S$ aluminum X-baskets and placed in the ETR prior to the startup of ETR Cycle 4, which began on August 9, 1958. The capsules were positioned symmetrically around the vertical midposition of the core in order to insure that the maximum number of specimens were located in the regions of highest flux. The capsules were first located in the F-10 position, prior to the use of this position as a site for a test loop. The capsules were maintained in this position until the end of Cycle 11, at which time the core-filler piece was transferred with all capsules intact to the $K-7$ position. The capsules were irradiated in the K-7 position during Cycle 12 and were then transferred to the $K-8$ and $L-8$ positions, where they remained until the end of Cycle 30, with the exception of Capsule BMI-24-14, which was discharged at the end of Cycle 28. The capsules were moved to the G-13 position for Cycles 31 through 33, then moved intact to the I- 13 position.

During the period of August, 1958, to mid-January, 1962, three capsules were discharged from the ETR, and three capsules were added to the group of eight originally inserted. Capsules BMI-24-18, -20 , and -22 , each of which contained six subsize tensile and six cyclic-strain fatigue specimens, were inserted on top of existing capsules in the northwest, northeast, and southeast quadrants, respectively, of the core-filler piece prior to the startup of Cycle 19 (August 18, 1959). Capsules BMI-24-6 and BMI-24-18 were removed from the reactor at the end of Cycle 42 (January 15, 1962) for testing. Room-temperature and $600 \mathrm{~F}$ tests were conducted for six specimens each at exposures of about $6.5 \times 10^{21}$ and $1.1 \times 10^{22}$ nvt. Capsule BMI-24-14, which contained six standard Charpy $\mathrm{V}$-notch and twelve subsize Izod specimens, was discharged at the end of Cycle 28 (May 23, 1960) and shipped to the Battelle hot cells for postirradiation examinations. A summary of the individual capsules with respect to their irradiation position in the ETR during the period of time from Cycle 4 (August 9, 1958) to Cycle 40 (October 2, 1961) is given in Table 3. These irradiations are continuing with the exceptions noted above.

\section{Capsule Dosimetry}

A study was carried out as part of the irradiation program to determine as accurately as possible the fast-neutron flux (neutrons having energies greater than $1 \mathrm{Mev}$ ) to which the specimens were subjected. A vertical flux profile was obtained in quadrants 
TABLE 3. LOCATION OF BMI-24 CAPSULES DURING IRRADIATION IN THE ETR

\begin{tabular}{|c|c|c|c|}
\hline ETR Cycle & $\begin{array}{l}\text { BMI-24 Series } \\
\text { Capsule }\end{array}$ & Position & $\begin{array}{c}\text { Distance From Top of Capsule Array } \\
\text { to Top of Lattice, in. }\end{array}$ \\
\hline \multirow[t]{2}{*}{4 through 11} & $4,2,14$, and 6 & $F-10-N E$ & $\begin{array}{c}3-1 / 4 \text { to } 10-1 / 2 ; 10-1 / 2 \text { to } 17-3 / 4 \\
17-3 / 4 \text { to } 25-3 / 4 ; 25-3 / 4 \text { to } 33\end{array}$ \\
\hline & $8,10,16$, and 12 & $F-10-S E$ & $\begin{array}{c}3=1 / 4 \text { to } 10-1 / 2 ; 10-1 / 2 \text { to } 17-3 / 4 \\
17-3 / 4 \text { to } 25-3 / 4 ; 25-3 / 4 \text { to } 33\end{array}$ \\
\hline 12 & $\begin{array}{l}4,2,14, \text { and } 6 \\
8,10,16, \text { and } 12\end{array}$ & $\begin{array}{l}\mathrm{K}-7-\mathrm{NW} \\
\mathrm{K}-7-\mathrm{SE}\end{array}$ & $\begin{array}{l}\text { Same relative vertical position as above } \\
\text { Ditto }\end{array}$ \\
\hline \multirow{4}{*}{13 through 18} & 14 and 16 & $\mathrm{~K}-8-\mathrm{NW}$ & 15 to $23 ; 23$ to 31 \\
\hline & 2 and 6 & $K=8-N E$ & $13-1 / 2$ to $20-3 / 4 ; 20-3 / 4$ to 28 \\
\hline & 4,8, and 10 & $\mathrm{~K}-8 \infty \mathrm{SE}$ & $\begin{array}{l}11-1 / 4 \text { to } 18=1 / 2 ; 18-1 / 2 \text { to } 25-3 / 4 ; \\
25-3 / 4 \text { to } 33\end{array}$ \\
\hline & 12 & $\mathrm{~L}-8 \sim \mathrm{SE}$ & $15-1 / 4$ to $22-1 / 2$ \\
\hline \multirow[t]{4}{*}{19 through 30} & 18,14, and 16 & $K=8-N W$ & $7-3 / 4$ to $15 ; 15$ to $23 ; 23$ to 31 \\
\hline & 20,2, and 6 & $\mathrm{~K}-8-\mathrm{NE}$ & $\begin{array}{l}6-1 / 4 \text { to } 13-1 / 2 ; 13-1 / 2 \text { to } 20-3 / 4 \\
20-3 / 4 \text { to } 28\end{array}$ \\
\hline & 4,8, and 10 & $\mathrm{~K}-8-\mathrm{SE}$ & $\begin{array}{l}11-1 / 4 \text { to } 18-1 / 2 ; 18-1 / 2 \text { to } 25-3 / 4 \text {; } \\
25-3 / 4 \text { to } 33\end{array}$ \\
\hline & 22 and 12 & $L-8-S E$ & 8 to $15-1 / 4 ; 15-1 / 4$ to $22-1 / 2$ \\
\hline \multirow[t]{4}{*}{31 through 33} & 18 and 16 & $G=13-N W$ & 16 to $23-1 / 4 ; 23-1 / 4$ to $30-1 / 2$ \\
\hline & 20,2, and 6 & $\mathrm{G}-13-\mathrm{NE}$ & $\begin{array}{l}6-1 / 4 \text { to } 13-1 / 2 ; 13-1 / 2 \text { to } 20-3 / 4 ; \\
20-3 / 4 \text { to } 28\end{array}$ \\
\hline & 4,8, and 10 & $\mathrm{G}-13-\mathrm{SE}$ & $\begin{array}{l}11-1 / 4 \text { to } 18-1 / 2 ; 18-1 / 2 \text { to } 25 \infty 3 / 4 \\
25-3 / 4 \text { to } 33\end{array}$ \\
\hline & 22 and 12 & $G-13-S W$ & $8-1 / 4$ to $15-1 / 2 ; 15-1 / 2$ to $22 m 3 / 4$ \\
\hline \multirow[t]{4}{*}{34 through 40} & 18 and 16 & $I-13-\mathrm{NW}$ & Same relative vertical position as above \\
\hline & 20,2, and 6 & $\mathrm{I}-13=\mathrm{NE}$ & Ditto \\
\hline & 4,8, and 10 & $\mathrm{I}=13 \times \mathrm{SE}$ & Ditto \\
\hline & 22 and 12 & $\mathrm{I}-13-\mathrm{SW}$ & Ditto \\
\hline
\end{tabular}


of the core-fillex piece each time the capsules were relocated, or periodically when the capsules were stationary over a period of time. The measurements were made in one quadrant of the core-filler piece along the length of contained specimens by means of point flux measurements every 3 to $6 \mathrm{in}$. Measurements were also taken at the 20-7/8in. level of the other three quadrants and the center, and this information was used to extrapolate flux values over the capsule-containing length of these quadrants.

A number of nuclear reactions were considered and/or tested for fast- and thermalneutron flux determinations. The two reactions initially chosen were $\mathrm{Ni}^{58}(\mathrm{n}, \mathrm{p}) \mathrm{Co}^{58}$ and $\mathrm{S}^{32}(\mathrm{n}, \mathrm{p}) \mathrm{P}^{32}$. Additional reactions considered and/or tested are shown in Table 4.

TABLE 4. NUCLEAR REACTIONS USED OR CONSIDERED FOR USE IN DETERMINING FAST AND THERMAL FLUX

\begin{tabular}{|c|c|c|c|}
\hline Reaction & $\begin{array}{c}\text { Effective Neutron } \\
\text { Energy Threshold(a) } \\
\text { Mev }\end{array}$ & $\begin{array}{c}\text { Half-Life of } \\
\text { Nuclide Formed }\end{array}$ & $\begin{array}{l}\text { Cross } \\
\text { Section, } \\
\text { barns }\end{array}$ \\
\hline$s^{32}\left(n_{g} p\right) P^{32}$ & 3.9 & 14. 3 days & 0.060 \\
\hline $\mathrm{Ni}^{58}\left(\mathrm{n}_{\mathrm{z}} \mathrm{p}\right) \mathrm{Co}^{58}$ & 4.0 & 71.3 days & 0.092 \\
\hline $\mathrm{Fe}^{54}(\mathrm{n}, \mathrm{p}) \mathrm{Mn}^{54}$ & 4.3 & 300 days & 0.054 \\
\hline $\mathrm{Cu}^{63}\left(\mathrm{n}_{8} a\right) \mathrm{Co}^{60}$ & 9.2 & $5.27 \mathrm{yr}$ & 0.00072 \\
\hline $\mathrm{Co}^{59}(\mathrm{n}, y) \mathrm{Co}^{60}$ & Thermal & $5.27 \mathrm{yr}$ & 37 \\
\hline $\begin{array}{l}\mathrm{Co}^{59}(\mathrm{n}, \gamma) \mathrm{Co}^{60} \\
\text { (cadmium shielded) }\end{array}$ & Epithermal & $5.27 \mathrm{yr}$ & 70 \\
\hline
\end{tabular}

(a) From Reference (5).

The first dosimeter as emblies were prepared from 36-in. -long aluminum tubing which contained short lengths of high-purity nickel wire and small quantities of ammonium sulfate sealed in quartz and spaced inside the aluminum tubing by glass-wool plugs. These dosimeter assemblies were irradiated in the F-10 position of the ETR during Cycles 10, 11, and 12, and returned to Battelle for analysis. All of the ammonium sulfate was rendered useless because of decomposition of the compound during irradiation. The nickel wires were analyzed by comparing the photopeak area of the $0.81-\mathrm{Mev}$ gamma ray from cobalt-58 produced in the nickel wires with the $0.84-\mathrm{Mev}$ gamma photopeak from a manganese-54 standard, as measured on a sodium iodide, welltype scintillation crystal. A factor of 0.692 was used to correct the neutron-flux values for the fraction of neutrons having energies greater than $1 \mathrm{Mev}$. Calculations of the instantaneous flux were on the basis of full-power (175-megawatt) operation. Subsequent dosimeters were prepared similarly, except that they did not contain the ammonium sulfate.

Considerable nickel-wire dosimetry data were obtained for the $\mathrm{K}-8$ position of the ETR during the time this position was occupied by the capsules. A complete vertical flux profile was obtained, based on nickel-wire analysis, for the $\mathrm{K}-8$ west quadrant during Cycle 13A. In addition, flux values were obtained for wires positioned in the assumed maximum-flux position (about 20-7/8 in. below the top of the core-filler piece) of the east, north, and south quadrants of $\mathrm{K}-8$. The measurements were repeated on 
wires exposed in the same relative locations of $\mathrm{K}-8$ during Cycles 15, 16, and 17, and a much lower set of flux values was obtained. Dosimeters from the 20-7/8-in. level of $\mathrm{K}-8$ were analyzed after exposure for Cycles 18, 19, and 20 in the north, center, and east positions and data were obtained from a single-cycle exposure in $\mathrm{K}-8$ north, south, and east (Table 5).

Some of the data presented in Table 5 have been rearranged in Table 6 to give a clearer picture of the effects of multicycle irradiations and long exposures on the accuracy of nickel dosimetry. The data indicate that an inverse correlation exists between the length of irradiation time and the nickel-dosimeter-derived flux values. Using the Cycle $13 \mathrm{~A}$ values as a comparison, the values of dosimeters exposed in comparable locations of K-8 range from 39 to 44 per cent, 28 to 33 per cent, and 58 to 60 per cent of Cycle 13A values for dosimeters exposed in Cycles 15 through 17, Cycles 18 through 20, and Cycle 21, respectively. The total operating time for Cycles 13A, 15 through 17, 18 through 20 , and 21 was $2.35,19.3,29.1$ and 4.6 megawatt-days, respectively.

The selection of nickel wire for dosimetry was based on the conversion of nickel-58 to cobalt -58 by an $(n, p)$ reaction, where the neutron absorbed is a fast neutron. The cobalt -58 activity was measured and then, allowing for decay, calculations of the integrated fast-neutron flux were made. However, the results shown in Tables 5 and 6 , as obtained by nickel-wire dosimetry, demonstrated conclusively that another reaction reduced the final activity of the cobalt -58 sample. The subsequent reaction is believed to be caused by the absorption of a thermal neutron by the cobalt-58. This reaction is: $\mathrm{Co}^{58}(\mathrm{n}, \gamma) \mathrm{Co}^{59}$. The product of this reaction is a stable nuclide having a cross section of $1650 \pm 150$ barns. Thus, in an irradiation experiment the loss or burnup of cobalt-58 is controlled by two factors: (1) its inherent 71.3-day half-life for radioactive decay and (2) its conversion to cobalt-59 by thermal-neutron capture. The effect of thermalneutron capture is to shorten the effective half-life of cobalt-58 while it is under irradiation. For instance, the effective half-life of cobalt-58 would be about 66.3 days in a thermal-neutron flux of $5 \times 10^{12}$ compared with only 8.5 days $(6)$ in a thermal-neutron flux of $5 \times 10^{14} \mathrm{nv}$.

Because of the current uncertainty involved in applying corrections to data obtained from nickel dosimeters exposed for long irradiations in regions of high thermal-neutron flux, a study was initiated to select a dosimeter that would be less sensitive to errors due to high thermal flux or long-term irradiations. The $\mathrm{Fe}^{54}(\mathrm{n}, \mathrm{p}) \mathrm{Mn}{ }^{54}$ reaction appeared worthy of consideration because of the longer half-life ( 300 days), an estimated cross section of 0.054 barn (current values range from 0.051 to 0.065 barn), and the fact that burnup due to thermal-neutron absorption is insignificant. The system may also be adapted to determine the fast-neutron flux by examination of portions of the iron-bearing specimens themselves. The analytical technique used for determining fast flux from manganese -54 produced in irradiated iron wires was as follows:

(1) A known weight of iron dosimeter was dissolved in hydrochloric acid and diluted to a known volume. An ion-exchange column was prepared by slurrying Dowex $2-\mathrm{X}-8,100$ to $200 \mathrm{mesh}$, in a glass tube $5 \mathrm{~cm}$ long with an inside diameter of about $1.3 \mathrm{~cm}$. In order to regulate the flow, a stopcock was placed below the column, and an inlet funnel equipped with a stopcock and ground-glass joint was fitted above the column. The resin was initially activated by passing concentrated hydrochloric acid through the column at a rate of about $1 \mathrm{ml}$ per min. 
12

TABLE 5. RESULTS OF ETR DOSIMETRY EXPERIMENTS FOR CYCLES 13A THROUGH 21

\begin{tabular}{|c|c|c|c|}
\hline $\begin{array}{l}\text { Reactor } \\
\text { Posicion } \\
\end{array}$ & $\begin{array}{c}\text { Distance from } \\
\text { Top of Reflectors } \\
\text { in. }\end{array}$ & $\begin{array}{c}\begin{array}{c}\text { Fast-Neutron } \\
(>1 \text { Mev) Flux } \\
10^{14} \mathrm{nv}\end{array} \\
\end{array}$ & $\begin{array}{c}\text { Calculated Total } \\
\text { Fuil -Power (175 Megawatts) } \\
\text { Irradidtion Time, days }\end{array}$ \\
\hline \multicolumn{4}{|c|}{ Cycle 13a } \\
\hline \multirow[t]{8}{*}{$\mathrm{K}-8$ West } & $2-3 / 8$ & 0.53 & \\
\hline & 7 & 1.5 & \\
\hline & $11-5 / 8$ & 2.0 & \\
\hline & $16-1 / 4$ & 2.4 & \\
\hline & $20-7 / 8$ & 2.6 & 2.35 \\
\hline & $25-1 / 2$ & 2.6 & \\
\hline & $30-1 / 8$ & 2.3 & \\
\hline & $34-3 / 4$ & 1.7 & \\
\hline K-8 North & $20-7 / 8$ & 1.9 & \\
\hline $\mathrm{K}-8$ South & $20-7 / 8$ & 2.8 & \\
\hline $\mathrm{K}-8$ East & $20-7 / 8$ & 1.9 & \\
\hline \multicolumn{4}{|c|}{ Cycles 15,16, and 17} \\
\hline \multirow[t]{8}{*}{$\mathrm{K}-8 \mathrm{West}$} & $2-3 / 8$ & 0.32 & \\
\hline & 7 & 0.60 & \\
\hline & $11-5 / 8$ & 0.69 & \\
\hline & $20-7 / 8$ & 1.0 & \\
\hline & $16-1 / 4$ & 1.1 & \\
\hline & $25-1 / 2$ & 1.1 & 19.3 \\
\hline & $30-1 / 8$ & 1.1 & \\
\hline & $34-3 / 4$ & 0.88 & \\
\hline K-8 North & $20-7 / 8$ & 0.81 & \\
\hline K-8 East & $20-7 / 8$ & 0.83 & \\
\hline K-8 South & $20-7 / 8$ & 1.1 & \\
\hline \multicolumn{4}{|c|}{ Cycles 18,19, and 20} \\
\hline $\mathrm{K}-8$ Center & $20-7 / 8$ & 0.54 & \\
\hline $\mathrm{K}-8$ North & $20-7 / 8$ & 0.62 & 29.1 \\
\hline K-8 East & $20-7 / 8$ & 0.52 & \\
\hline \multicolumn{4}{|c|}{ Cycle 21} \\
\hline K-8 South & $20-7 / 8$ & 1.7 & \\
\hline $\mathrm{K} \oplus 8$ North & $20-7 / 8$ & 1.1 & 4.6 \\
\hline $\mathrm{K}-8$ East & $20-7 / 8$ & 1.1 & \\
\hline
\end{tabular}

TABLE 6. COMPARISON OF NICKEL-WIRE DOSIMETRY VALUES FOR ETR CYCLES 15 THROUGH 21

\begin{tabular}{|c|c|c|c|c|c|c|c|c|c|}
\hline \multirow[b]{2}{*}{ Cycle } & \multirow[t]{2}{*}{$\begin{array}{c}\text { Calculated Total } \\
\text { Full-Power } \\
\text { (1.75 Megawatts) } \\
\text { Irradiation Time, } \\
\text { days } \\
\end{array}$} & \multicolumn{4}{|c|}{$\begin{array}{l}\text { Fast-Neutron ( }>1 \text { Mev) Fiux at } \\
\text { Vertical Position } 20-7 / 8 \text { in, below } \\
\text { Top of Filler Piece, } 10^{14} \text { nv }\end{array}$} & \multicolumn{4}{|c|}{$\begin{array}{l}\text { Relative Exposure, per cent of } \\
\text { Cycle } 13 \text { A flux values }\end{array}$} \\
\hline & & North & South & East & West & North & South & E.ast & West \\
\hline $13 \mathrm{~A}$ & 2.35 & 1.9 & 2.8 & 1.9 & 2.6 & 100 & 100 & 100 & 100 \\
\hline $15,16,17$ & 19.3 & 0.81 & 1.1 & 0.83 & 1.1 & 43 & 39 & 44 & 42 \\
\hline $18,19,20$ & 29.1 & 0.62 & $-\infty$ & 0.52 & - & 33 & $-\infty$ & 28 & $-\infty$ \\
\hline 21 & 4.6 & 1.1 & 1.7 & 1.1 & $-\infty$ & 60 & 58 & 58 & $=\infty$ \\
\hline
\end{tabular}


(2) An aliquot of the dissolved specimen was placed on the column through the funnel. The manganese-54 was eluted by passing $8.5 \mathrm{~N} \mathrm{HCl}$ through the colunm at about $1 \mathrm{ml}$ per min. An aliquot of the effluent was then radioassayed for manganese -54 .

The above technique worked equally well with dis solved stainless steel specimens since the cobalt-60 produced in the stainless steel specimens remains on the column if the $\mathrm{HCl}$ normality remains at 8.5 or higher, whereas the manganese is completely removed.

A comparison of the fast-neutron flux determined by different techniques was made in the G-13 position of the ETR during Cycle 32 (30.3 days at 175 megawatts). Three types of dosimeters assemblies were irradiated, including nickel, nickel-cobalt, and iron wires. The nickel and iron wires were for determination of fast flux, and the nickel-cobalt was for determination of thermal flux. The fast-neutron-flux data are reported in Table 7 both uncorrected and corrected for thermal burnup based on a $\mathrm{Co}^{58}(\mathrm{n}, \gamma) \mathrm{Co}^{59}$ cross section of 1650 barns. The iron wires contained iron-59 and manganese -54 as the principal sources of radioactivity after irradiation. The manganese -54 was radioassayed both in conjunction with the iron-59 and after ionexchange separation. It was noted that the uncorrected data for the nickel wires gave values of about one-half the instantaneous flux obtained from those corrected for thermal burnup. Results from iron-wire dosimeters were higher than corrected values from the nickel dosimeters. Those assayed directly without separation of the iron-58 from the iron-59 gave values 15 to 20 per cent higher than samples analyzed after separation of manganese-54 by the ion-exchange technique. The difference between values for separated and unseparated samples was attributed to errors in simultaneous counting techniques rather than to loss of manganese-54 during the separation process.

Evaluation of the $\mathrm{Fe}^{54}(\mathrm{n}, \mathrm{p}) \mathrm{Mn}^{54}$ reaction as a fast-flux monitor was performed by analysis of portions of Type 347 stainles steel specimens irradiated during Cycles 6 and 7, Cycle 11, and Cycles 4 through 28. Filings from these specimens were prepared in the manner previously discussed, and the effluent from the ion-exchange column was analyzed by gamma-ray spectrometry. The results of the analyses are presented in Table 8. It was noted that remarkably good correlation existed between the flux values obtained on the basis of extrapolation of values obtained at low power with nickel-wire dosimetry, and the values as determined through the $F e^{54}(n, p) M n^{54}$ reaction, particularly for those specimens which were maintained in-pile for the long-term irradiation. It should be noted that if uncorrected values for the nickel-wire samples rather than extrapolated values had been employed to determine total exposure, the apparent integrated fast flux would have been lower by a factor of two or more.

\section{Status of Irradiations}

The estimated fast-neutron flux exposures for capsules in the surveillance program as of the end of ETR Cycle 40 (October 2, 1961) are given in Table 9. These data were obtained from fast-flux determinations made by ETR and Battelle personnel. The data were corrected to allow for the length of irradiation and the thermal-neutron flux levels, if nickel-wire dosimetry was used. Where the results of both nickel and iron dosimetry were available for a particular cycle and location, the neutron flux determined by the lattex method was employed to obtain the integrated neutron exposures. Dosimeters recovered since ETR Cycle 40 have been stored in the interests of economy and are now being analyzed. Dosimeters recovered from Capsules BMI-24-6 and BMI-24-16, which 
TABLE 7. COMPARISON OF NEUTRON FLUX VALUES OBTAINED BY DIFFERENT TECHNIOUES DURING CYCLE 32

\begin{tabular}{|c|c|c|c|c|c|}
\hline \multirow{2}{*}{$\begin{array}{c}\text { Wire } \\
\text { Position }\end{array}$} & \multicolumn{4}{|c|}{$\begin{array}{l}\text { Fast-Neutron Flux }(>1 \mathrm{Mev}) \text { Based on } \\
\text { Indicated Isotope, nv }\end{array}$} & \multirow{2}{*}{$\begin{array}{l}\text { Thermal- } \\
\text { Neutron } \\
\text { Flux } \\
\text { Based on } \\
\text { Co60, nv }\end{array}$} \\
\hline & $\mathrm{Co}^{58(a)}$ & $\cos 8(b)$ & $\operatorname{Mn} 54(c)$ & $\mathrm{Mn}^{54(\mathrm{~d})}$ & \\
\hline South-4 & $6.0 \times 10^{13}$ & $1.3 \times 10^{14}$ & $1.8 \times 10^{14}$ & $1.5 \times 10^{14}$ & $4.1 \times 10^{14}$ \\
\hline East-4 & $6.9 \times 10^{13}$ & $1.2 \times 10^{14}$ & $2.1 \times 10^{14}$ & $1.7 \times 10^{14}$ & $2.5 \times 10^{14}$ \\
\hline West- 4 & $4.3 \times 10^{13}$ & $8.8 \times 10^{13}$ & $1.4 \times 10^{14}$ & Lost & $3.9 \times 10^{14}$ \\
\hline
\end{tabular}

(a) Uncorrected.

(b) Corrected for thermal burnup of $\mathrm{Co}^{58}$.

(c) Simultaneous counting of $\mathrm{Mn}^{54}$ and $\mathrm{Fe}^{59}$ withour separation.

(d) Ion-exchange separation of $\mathrm{Mn}^{54}$.

TABLE 8. COMPARISON OF FAST-NEUTRON FLUX VALUES BASED ON EXTRAPOLATED NICKEL-WIRE DOSIMETRY DATA AND ON ANALYSIS OF IRRADIATED STAINLESS STEEL SAMPLES

\begin{tabular}{|c|c|c|c|c|c|}
\hline \multirow{3}{*}{$\begin{array}{l}\text { ETR } \\
\text { Irradiation } \\
\text { Cycles }\end{array}$} & \multirow{3}{*}{$\begin{array}{c}\text { Calculated Total Full-Power } \\
\text { (175 Megawatts) Irradiation } \\
\text { Time, days }\end{array}$} & \multicolumn{4}{|c|}{ Fast-Neutron Flux $(>1 \mathrm{Mev})$} \\
\hline & & \multicolumn{2}{|c|}{$\begin{array}{l}\text { Extrapolated Low Power Values Based } \\
\text { on Nickel-Wire Dosimetry }\end{array}$} & \multicolumn{2}{|c|}{$\begin{array}{l}\text { Determined by(a) Manganese-54 } \\
\text { Assay of Stainless Steel Sample }\end{array}$} \\
\hline & & NV & NVT & NV & NVT \\
\hline 6 and 7 & 18.8 & $2.4 \times 10^{14}$ & $3.9 \times 10^{20}$ & $2.1 \times 10^{14}$ & $3.4 \times 10^{20}$ \\
\hline 6 and 7 & 18.8 & $2.4 \times 10^{14}$ & $3.9 \times 10^{20}$ & $2.2 \times 10^{14}$ & $3.6 \times 10^{20}$ \\
\hline 11 & 7.5 & $2.0 \times 10^{14}$ & $1.3 \times 10^{20}$ & $2.2 \times 10^{14}$ & $1.4 \times 10^{20}$ \\
\hline 11 & 7.5 & $2.0 \times 10^{14}$ & $1.3 \times 10^{20}$ & $2.2 \times 10^{14}$ & $1.4 \times 10^{20}$ \\
\hline 4 through 28 (b) & 270 & $\begin{array}{l}\text { Varied from } \\
1.9 \text { to } 3.0 \\
\times 10^{14} \\
\text { during the } \\
24 \text {-cycle } \\
\text { irradiation }\end{array}$ & $\begin{array}{l}5.7 \text { to } 5.8 \\
\times 10^{21}\end{array}$ & $2.3 \times 10^{14}$ & $5.5 \times 10^{21}$ \\
\hline 4 through 28 & 270 & Ditto & $\begin{array}{l}5.7 \text { to } 5.8 \\
\times 10^{21}\end{array}$ & $2.6 \times 10^{14}$ & $6.0 \times 10^{21}$ \\
\hline
\end{tabular}

(a) The integrated fast flux was determined by calculating the production of manganese in each separate cycle and correcting for decay of the radioisotope between cycles.

(b) This capsule was in-pile from June, 1958, to May, 1960. 
were discharged from the ETR on about January 15, 1962, indicated an exposure of about $0.93 \times 10^{22}$ to $1.1 \times 10^{22}$ and $5.1 \times 10^{21}$ to $7.4 \times 10^{21}$ nvt, respectively.

TABLE 9. SUMMARY OF BMI-24 SURVEILLANCE-CAPSULE EXPOSURES AS OF END OF CYCLE 40

\begin{tabular}{|c|c|c|c|c|}
\hline \multirow[b]{2}{*}{ Capsule } & \multirow{2}{*}{$\begin{array}{c}\text { Type of Specimens } \\
\text { in Capsule }\end{array}$} & \multicolumn{2}{|c|}{$\begin{array}{c}\text { Total Exposure as of } \\
\text { End of Cycle } 40 \\
(10-2-61), \times 10^{21} \\
\text { nvt }\end{array}$} & \multirow[b]{2}{*}{ Remarks } \\
\hline & & Top & Bortom & \\
\hline $\mathrm{BMI}-24-2$ & Tensile and fatigue & 8.7 & 10.3 & In-pile since Cycle 4 \\
\hline BMI $-24-4$ & Tensile and fatigue & 7.0 & 9.3 & In-pile since Cycle 4 \\
\hline BMI $-24-6$ & Tensile and fatigue & $11.0(a)$ & $8.4^{(a)}$ & In-pile since Cycle 4 \\
\hline $\mathrm{BMI}-24-8$ & Tensile and fatigue & 8.4 & 9.0 & In -pile since Cycle 4 \\
\hline BMI $-24-10$ & Tensile and fatigue & 9.1 & 7.4 & In-pile since Cycle 4 \\
\hline BMI $-24-12$ & Tensile and fatigue & 9.7 & 9.7 & In-pile since Cycle 4 \\
\hline BMI-24-14(b) & Impact & 5.8 & 5.6 & $\begin{array}{l}\text { Discharged from reactor at } \\
\text { end of Cycle } 28 \text {, and } \\
\text { specimens tested }\end{array}$ \\
\hline $\mathrm{BMI}-24-16^{(b)}$ & Impact & 9.7 & 8.4 & In-pile since Cycle 4 \\
\hline BMI $-24-18$ & Tensile and fatigue & $4.4^{(a)}$ & $6.4(a)$ & In-pile since Cycle 19 \\
\hline BMI $-24-20$ & Tensile and fatigue & 4.4 & 6.4 & In-pile since Cycle 19 \\
\hline BMI $-24-22$ & Tensile and fatigue & 4.6 & 6.2 & In-pile since Cycle 19 \\
\hline
\end{tabular}

(a) Capsules BMI-24-6 and BMI-24-18 were discharged from the reactor at the end of Cycle 42 (about January 15, 1962) with exposures of about $0.93 \times 10^{22}$ to $1.1 \times 10^{22}$ and $5.1 \times 10^{21}$ to $7.4 \times 10^{21} \mathrm{nvt}$, respectively.

(b) Capsules BMI-24-14 and -16 contain 12 subsize modified Izod specimens and 6 regular size charpy $V$ notch specimens. All other capsules contain, 6 each subsize tensile and cycle-strain fatigue specimens.

\section{Status of Mechanical-Property Studies}

As noted earlier, 9 of the 11 surveillance capsules contained subsize tensile and cyclic-strain fatigue-test specimens of Type 347 stainless steel. The cyclic-strain fatigue test differs from the more conventional fatigue tests in that specimens are subjected to considerably higher and constant alternating strain, tension, and compression during each cycle. In cyclic-strain fatigue testing, the specimens are allowed to cycle under a controlled cyclic strain, and the number of cycles to fracture is determined.

Personnel at KAPL designed and constructed equipment for testing small cylindrical bars of AISI Type 347 stainless steel, and obtained cyclic-strain data on unirradiated specimens at temperatures up to about $600 \mathrm{C}$ for strain ranges of 0.0035 to 0.020 in. per in. (0.35 to 2.0 per cent total strain). (7) Battelle constructed similar equipment and performed room-temperature tests on unirradiated samples in preparation for cyclicstrain fatigue tests on irradiated specimens. 
Postirradiation tensile tests have been performed upon two groups of six subsize tensile specimens from Capsules BMI-24-18 and BMI-24-6 irradiated to exposures of about $6.5 \times 10^{21}$ and $1.1 \times 10^{22}$ nvt, respectively. Postirradiation impact tests have also been performed upon several Charpy and Izod specimens irradiated in process water to exposures of about $5.7 \times 10^{21}$ nvt. The results of these tests are discussed in the following sections.

\section{Postirradiation Studies of Surveillance Program Specimens}

Impact Specimens From Capsule BMI-24-14

Capsule BMI-24-14 was discharged from the K-8-NW position in the ETR at the end of Cycle 28, May 23, 1960. The capsule contained 6 standard Charpy V-notch impact specimens and 12 subsize Izod specimens that had been irradiated at process-water temperatures to an estimated exposure of about $5.7 \times 10^{21}$ nvt. After removal of the specimens from the capsule, it was noted that all of the specimens were covered with a light gray-to-reddish colored adherent deposit, which was presumed to be iron oxide. Otherwise, the specimens appeared to be in good condition.

Three of the Izod specimens were tested at room temperature and three were tested at temperatures slightly above liquid-nitrogen temperature (>-196 C). Two of the Charpy $V$-notch specimens were tested at room temperature, and two were tested at liquid-nitrogen temperatures. In order to provide a basis for evaluating the changes due to irradiation, five unirradiated Charpy and Izod specimens were tested at room temperature and three or four Charpy and Izod specimens were tested at or slightly above liquid-nitrogen temperature.

Results of the impact tests on Charpy and subsize Izod specimens are listed in Table 10. There appears to be no way to evaluate results obtained from the subsize Izod tests since the specimens did not break, but rather were bent by the hammer of the testing machine. It was noted that irradiation produced the same level of bend resistance in specimens tested at room temperature as was produced in the unirradiated control Izod specimens tested at liquid-nitrogen temperatures. Irradiated Izod specimens tested at liquid-nitrogen tempexature offered the most resistance to bending of any group of specimens tested to date. It was also noted that tears were produced in all irradiated specimens tested at both room and liquid-nitrogen temperatures. Tears were not observed in the notches of any unirradiated Izod control specimens. The appearance of the irradiated Izod specimens after testing at room temperature is shown in Figure 5.

Unirradiated Charpy V-notch specimens absorbed 111 to $133 \mathrm{ft}-1 \mathrm{~b}$ for fracture at room temperature, and 79 to $87 \mathrm{ft}-1 \mathrm{~b}$ for fracture at liquid-nitrogen temperature. The specimens irradiated to $5.7 \times 10^{21}$ nvt absorbed 65 and $66 \mathrm{ft}-1 \mathrm{~b}$ for fracture at room temperature, and 19.0 and $20.5 \mathrm{ft}-1 \mathrm{~b}$ for fracture at liquid-nitrogen temperature. The fracture surfaces of unirradiated and irradiated impact specimens are shown in Figures 6 and 7. The appearance of the fractured surfaces of unirradiated specimens tested at room and liquid-nitrogen temperatures suggested ductile fractures. The appearance of irradiated Charpy $V$-notch specimens tested at room temperature also indicate ductile fractures, while a mixture of brittle and ductile fractures was produced in irradiated specimens tested at liquid-nitrogen temperature as shown in Figure 7. 
TABLE 10. RESULTS OF IMPACT TESTS ON TYPE 347 STAINLESS STEEL CHARPY AND IZOD SPECIMENS

\begin{tabular}{|c|c|c|c|c|}
\hline $\begin{array}{c}\text { Type of } \\
\text { Specimen }(a)(b)\end{array}$ & $\begin{array}{l}\text { Number } \\
\text { Tested }\end{array}$ & $\begin{array}{l}\text { Specimen History and } \\
\text { Test Temperature }\end{array}$ & $\begin{array}{l}\text { Impact Energy, } \\
\mathrm{ft}-\mathrm{Ib}\end{array}$ & Remarks \\
\hline Subsize Izod & 5 & $\begin{array}{l}\text { Unirradiated controls tested at } \\
\text { room temperature }(20 \mathrm{C})\end{array}$ & $\begin{array}{l}9.5 ; 10.25 ; 10.25 \\
10.25 ; 10.1\end{array}$ & Ductile bend, no ears in notch \\
\hline Subsize Izod & 4 & $\begin{array}{l}\text { Unirradiated controls tested } \\
\text { slightly above liquid-nitrogen } \\
\text { temperature }\end{array}$ & $\begin{array}{l}13.25 ; 12.50 ; 13.0 \\
13.0\end{array}$ & Ductile bend, no tears in notch \\
\hline Subsize Izod & 3 & $\begin{array}{l}\text { Irradiated to } \sim 5.7 \times 10^{21} \mathrm{nvt}, \\
\text { tested at room temperature }(20 \mathrm{C})\end{array}$ & $12.75 ; 13.0 ; 13.0$ & Tears in notch \\
\hline Subsize Izod & 3 & $\begin{array}{l}\text { Irradiated to } \sim 5.7 \times 10^{21} \mathrm{nvt} \\
\text { tested slightly above liquid- } \\
\text { nitrogen temperature }(\mathrm{c})(>-196 \mathrm{C})\end{array}$ & $15.5 ; 15.0 ; 17.5$ & Tears in notch \\
\hline Charpy V notch & 5 & $\begin{array}{l}\text { Unirradiated controls tested at } \\
\text { room temperature }(20 \mathrm{C})\end{array}$ & $\begin{array}{l}111 ; 120 ; 133 ; \\
117 ; 127\end{array}$ & Ductile fracture \\
\hline Charpy V notch & 3 & $\begin{array}{l}\text { Unirradiated controls tested at } \\
\text { liquid-nitrogen temperature } \\
(-196 \mathrm{C})\end{array}$ & $87 ; 81 ; 79$ & Ductile fracture \\
\hline Charpy V notch & 2 & $\begin{array}{l}\text { Irradiated to } \sim 5.7 \times 10^{21} \mathrm{nvt} \\
\text { tested at room temperature }(20 \mathrm{C})\end{array}$ & $66 ; 65$ & Ductile fracture \\
\hline Charpy $V$ notch & 2 & $\begin{array}{l}\text { Irradiated to } \sim 5.7 \times 10^{21} \mathrm{nvt} \text {, } \\
\text { tested at liquid-nitrogen } \\
\text { temperature }(-196 \mathrm{C})\end{array}$ & $20.5 ; 19.0$ & Mixed ductile and brittle fracture \\
\hline
\end{tabular}

(a) Available energy for testing Izod specimens $60 \mathrm{ft}-\mathrm{lb}$.

(b) Available energy for testing Charpy specimens $240 \mathrm{ft}-\mathrm{lb}$.

(c) Transfer times from liquid-nitrogen bath to moment of hammer impact were 59,38 , and $49 \mathrm{sec}$, respectively. 


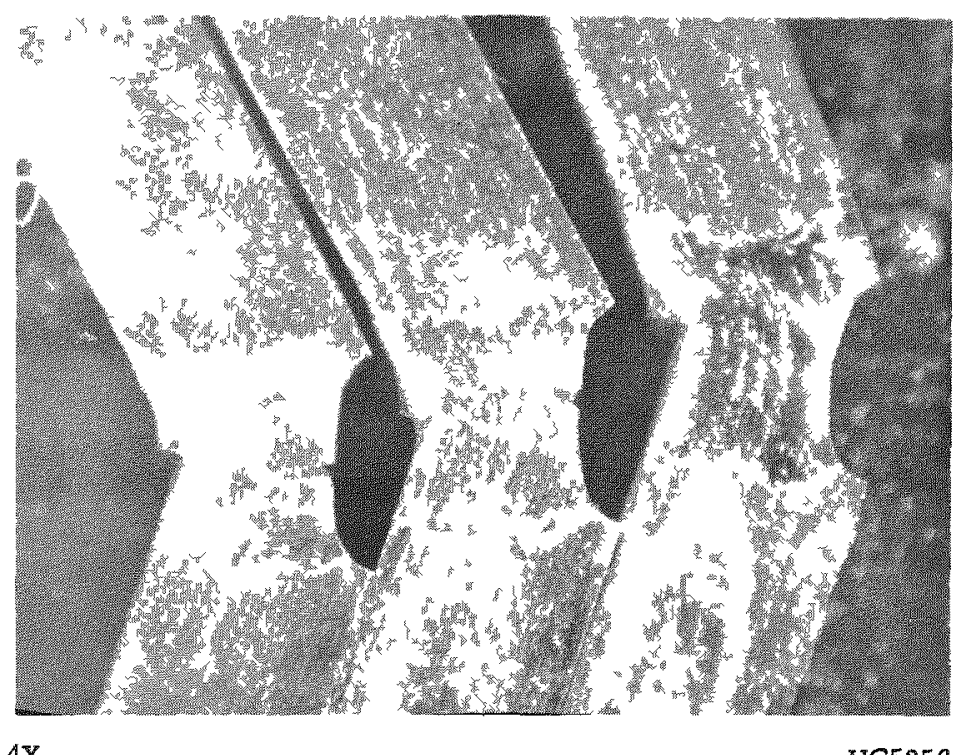

a. Side View

HC5356

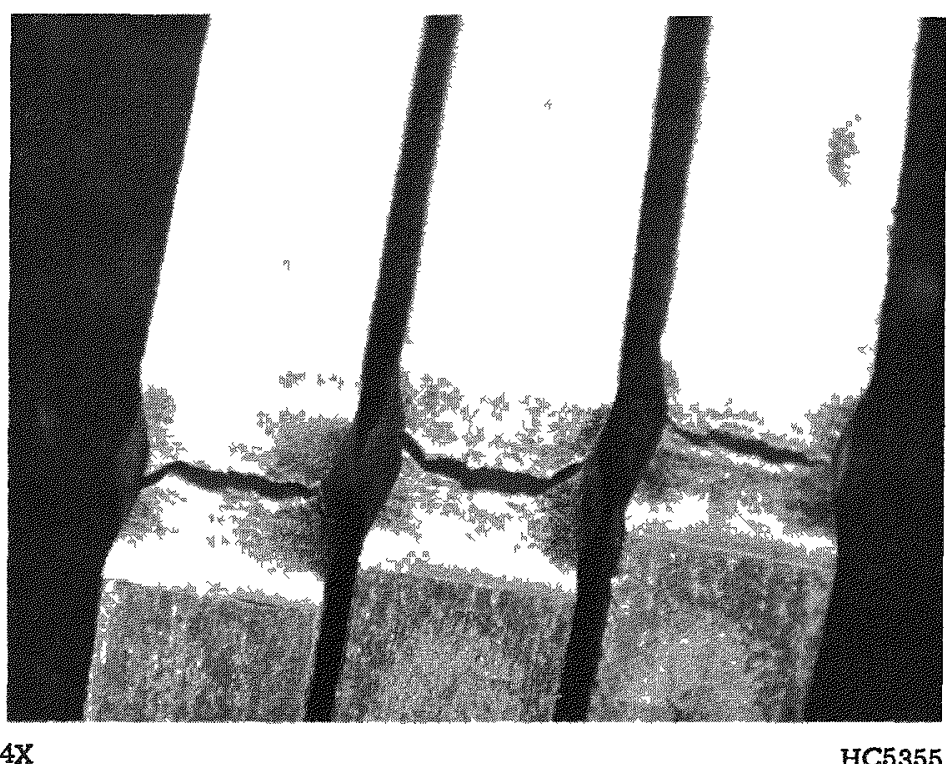

b. Top View

FIGURE 5. IRRADIATED SUBSIZE IZOD SPECIMENS AFTER TESTING

These impact-tested specimens were irradiated in process water to about $5.7 \times 10^{21} \mathrm{nvt}$. Note the tears on the reduced area and the presence of deposits on the surfaces of the specimens. 
A limited annealing study was carried out on the irradiated Type 347 stainless steel impact specimens to determine the effect of a $600 \mathrm{~F}$ anneal upon hardness. Two ir radiated Charpy and two irradiated Izod specimens were sectioned after testing and heated for 24-hr increments in air at $600 \mathrm{~F}$ to a total of $144 \mathrm{hr}$. Macrohardness measurements were obtained for the as-irradiated material and for material annealed 24:-, 48-,72-, 96-, and 144-hr intervals to determine the effect of annealing upon irradiated material. There was no appreciable decrease in hardness in the specimens following the various heating times, as compared with the as-irradiated samples, indicating that the $600 \mathrm{~F}$ temperature was too low to produce appreciable annealing.

\section{Tensile Tests of Irradiated Specimens}

The subsize tensile specimens contained in Capsules BMI-24-6 and BMI-24-18 were examined and tested. Capsule BMI-24-6 had been irradiated in various positions in the ETR for a total of 39 reactor cycles (from Cycle 4 through Cycle 42), and had. achieved maximum estimated fast flux exposures of about $1.1 \times 10^{22}$ nvt. Capsule BMI-24-18 had been irradiated from Cycle 19 through Cycle 42 and had achieved an average estimated fast flux exposure of about $5.5 \times 10^{21} \mathrm{nvt}$.

The appearance of tensile specimens when removed from the capsules is shown. in Figure 8. It was noted that all specimens were in good condition. Those removed from the longer exposure capsule (Capsule BMI-24-6) were more discolored with a deposit of light-reddish oxide than those removed from the shorter exposure capsule. Two specimens from each capsule were tested at room temperature (about $75 \mathrm{~F}$ ) and two were tested at $600 \mathrm{~F}$. The two remaining specimens of each capsule were annealed for a period of $1 \mathrm{hr}$ at $1800 \mathrm{~F}$ and tested at room temperature or $600 \mathrm{~F}$. The tests were performed with a Riehle universal testing machine at a constant strain rate of 0.005 in. per in. per min or slower from point of yield to specimen fracture. Measurements of elongation and reduction in area were obtained from calibrated photomacrographs. The results of the mechanical tests are given in Table 11.

Examination of the data in Table 11 shows that irradiation increased the 0.2 per cent offset yield strength about 190 per cent at room temperature, increased the ultimate strength about 24 per cent, and decreased the total elongation about 50 per cent. Similar changes in these properties were also observed in tests at $600 \mathrm{~F}$. The data indicated that the effects of increasing the neutron exposure from $6.5 \times 10^{21}$ to 1.1 $\times 10^{22}$ nvt were minor at both test temperatures, being reflected chiefly by differences in yield strength and total elongation.

The properties of specimens irradiated to different levels of exposure and subsequently annealed for $1 \mathrm{hr}$ at $1800 \mathrm{~F}$ before testing are also given in Table 11 . These results indicate that this annealing treatment was sufficient to remove nearly all effects of irradiation on the specimens. In particular, recovery of the yield and ultimate strengths of the stainless steel specimens was facilitated, whereas recovery of preirradiation ductility was not quite so complete, particularly in the specimens that received the higher irradiation exposure. A typical stress-strain curve of Type 347 stainless steel tested in the unirradiated condition at $75 \mathrm{~F}$, after irradiation to an estimated exposure of $1.1 \times 10^{22}$ nvt, and then after annealing is shown in Figure 9. The slope of the stress-strain curve obtained from irradiated specimens after a 1-hr anneal at $1800 \mathrm{~F}$ is almost identical to that of an unirradiated specimen, which illustrates the recovery of the preirradiation mechanical properties. 


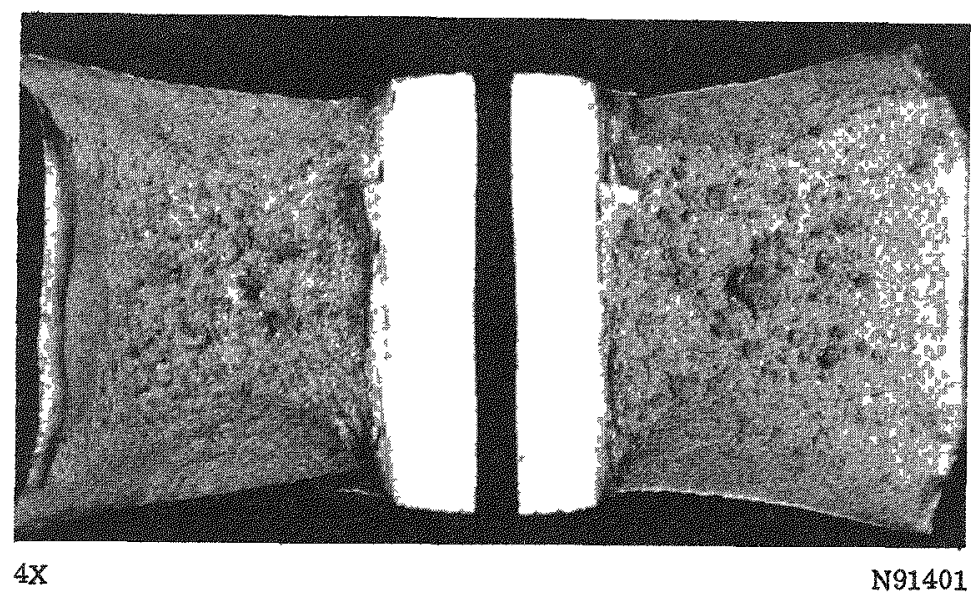

a. Tested at $20 \mathrm{C}, 120 \mathrm{Ft}-\mathrm{Lb}$

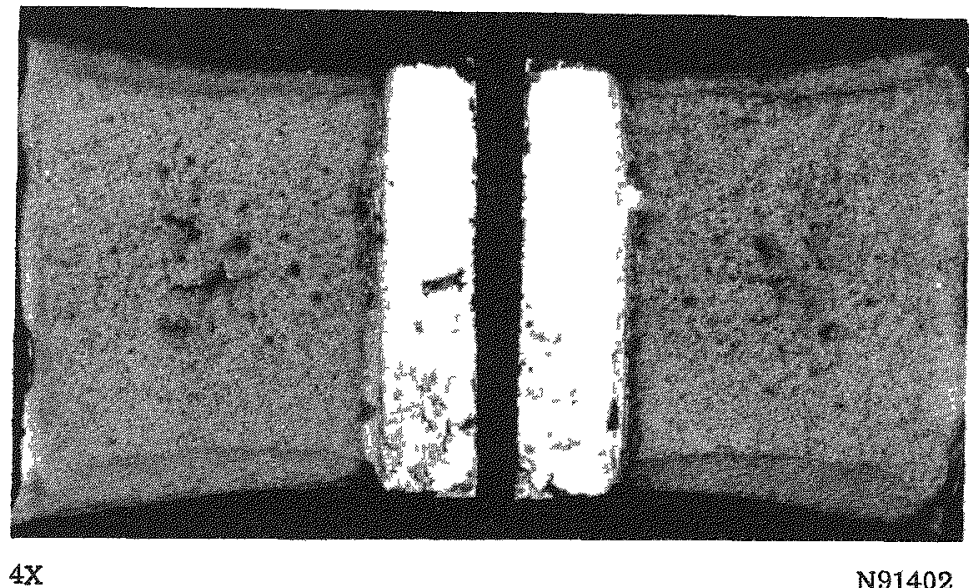

b. Tested at $-196 \mathrm{C}, \approx 80 \mathrm{Ft}-\mathrm{Lb}$

FIGURE 6. FRACTURE SURFACES OF UNIRRADIATED CHARPY V-NOTCH IMPACT SPECIMENS TESTED AT 20 AND $+106 \mathrm{C}$ 


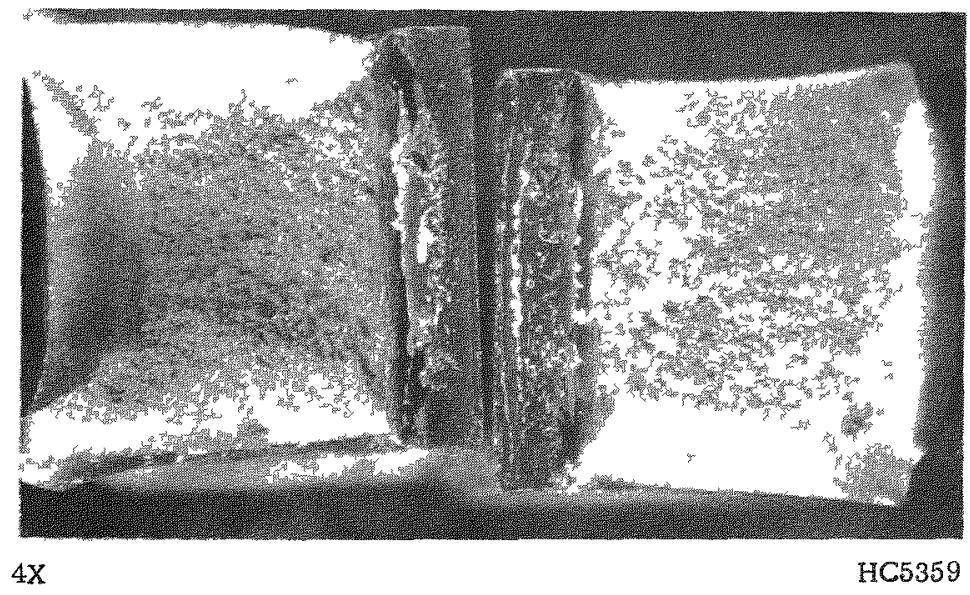

a. Tested at $20 \mathrm{C}, 65 \mathrm{Ft}-\mathrm{Lb}$

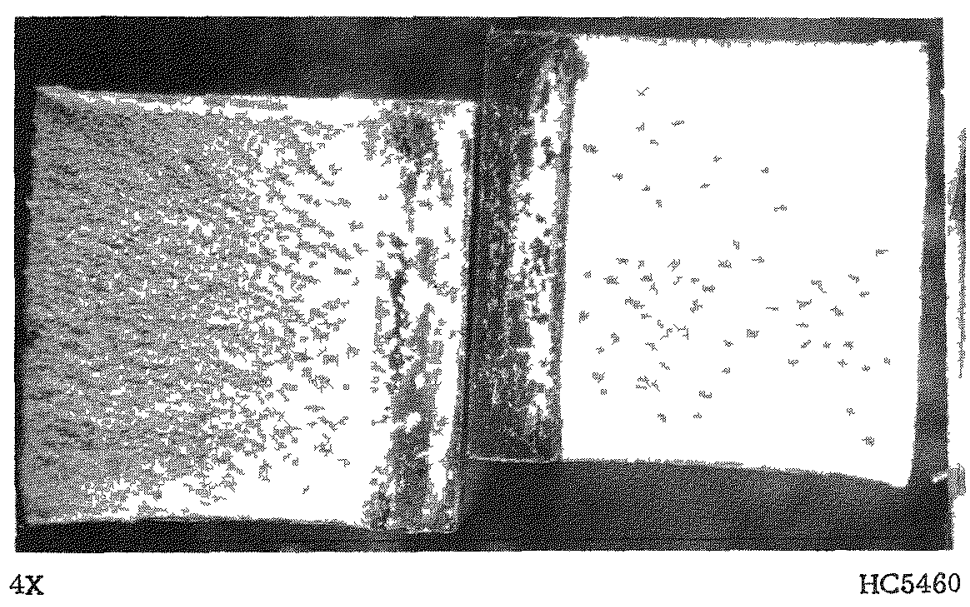

b. Tested at $-196 C_{8} \approx 20 \mathrm{Ft}-\mathrm{Lb}$

FIGURE 7. FRACTURE SURF ACES OF IRRADIATED CHARPY V-NOTCH IMPACT SPECIMENS TESTED AT 20 AND -196 C 


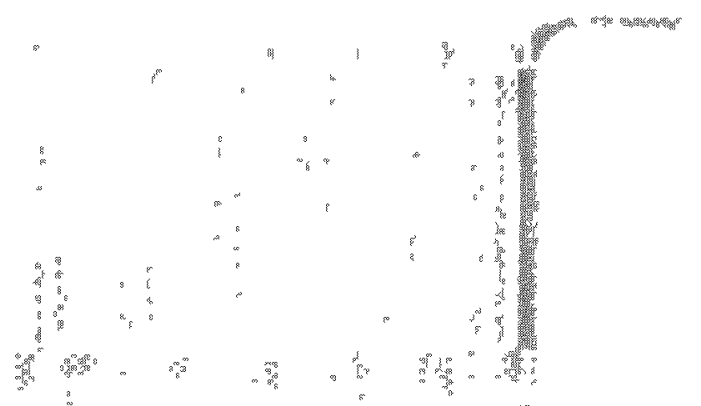

$$
\begin{array}{lllllll}
13 & 14 & 15 & 16 & 17 & 18
\end{array}
$$

a. Specimens from Capsule BMI-24-6

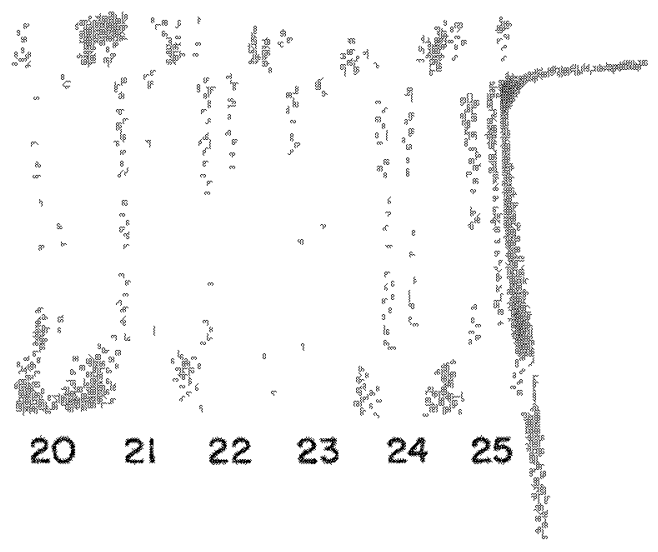

$1 \mathrm{X}$

HC8968

b. Specimens from Capsule BMI-24-18

FIGURE 8. TENSILE SPECIMENS IRRADIATED IN CONTACT WITH REACTOR PROCESS WATER 
TABLE 11. COMPARISON OF THE TENSILE PROPERTIES AT 75 AND 600 F OF UNIRRADIATED, IRRADIATED, AND IRRADIATED AND ANNEALED TYPE 347 ST AINLESS STEEL

\begin{tabular}{|c|c|c|c|c|c|c|c|}
\hline $\begin{array}{c}\text { Total } \\
\text { Integrated } \\
\text { Fast Flux, } \\
(>1 \mathrm{Mev}), \text { nvt }\end{array}$ & Capsule & Condition & $\begin{array}{l}0.2 \text { Per Cent } \\
\text { Offset Yield } \\
\text { Strength. } \\
1000 \mathrm{psi}\end{array}$ & $\begin{array}{c}\text { Ultimate } \\
\text { Tensile } \\
\text { Strength, } \\
1000 \text { psi }\end{array}$ & $\begin{array}{l}\text { Uniform } \\
\text { Elongation, } \\
\text { per cent }\end{array}$ & $\begin{array}{c}\text { Total } \\
\text { Elongation, } \\
\text { per cent in } \\
1.1 \mathrm{in.}\end{array}$ & $\begin{array}{l}\text { Reduction } \\
\text { of Area, } \\
\text { per cent }\end{array}$ \\
\hline \multicolumn{8}{|c|}{ Tested at $75 \mathrm{~F}$} \\
\hline 0 & -- & Unirradiated & 34.5 & 87.7 & $>40.0$ & 61.8 & 75.0 \\
\hline 0 & - & Unirradiated & 36.0 & 90.0 & $>40.0$ & 62.6 & 73.5 \\
\hline 0 & - & Unirradiated & 34.5 & 89.5 & $>40.0$ & 66.3 & 72.0 \\
\hline $0(a)$ & - & Unirradiated & 38.3 & 92.5 & - & 63.4 & 75.0 \\
\hline $0(a)$ & -- & Unirradiated & 38.7 & 92.8 & $\ldots$ & 64.7 & 76.0 \\
\hline $0(a)$ & $\sim$ & Unirradiated & 39.3 & 92.4 & $\cdots$ & 64.7 & 75.6 \\
\hline $7.6 \times 10^{21(b)}$ & BMI 24-18 & As irradiated & 104.0 & 112.0 & 25.8 & 34.5 & 68.5 \\
\hline $5.5 \times 10^{21(c)}$ & BMI 24-18 & As irradiated & 88.7 & 111.5 & 24.7 & 32.7 & 70.0 \\
\hline $1.1 \times 10^{22(c)}$ & BMI 24-6 & As irradiated & 103.5 & 112.5 & 24.3 & 30.9 & 70.0 \\
\hline $9.2 \times 10^{21(b)}$ & BMI 24-6 & As irradiated & 109.0 & 113.0 & 25.4 & 30.9 & 78.0 \\
\hline $1.1 \times 10^{22(c)}$ & BMI 24-18 & $\begin{array}{l}\text { Irradiated and annealed } \\
\text { at } 1800 \mathrm{~F} 1 \mathrm{hr}\end{array}$ & 33.0 & 87.1 & 52.1 & 55.5 & 75.0 \\
\hline $6.6 \times 10^{21}(\mathrm{~b})$ & BMI 24-6 & $\begin{array}{l}\text { Irradiated and annealed } \\
\text { at } 1800 \mathrm{~F} 1 \mathrm{hr}\end{array}$ & 33.8 & 87.5 & 57.5 & 61.0 & 77.0 \\
\hline \multicolumn{8}{|c|}{ Tested at $600 \mathrm{~F}$} \\
\hline $0(a)$ & $\ldots$ & Unirradiated & 26.9 & 63.8 & - & 36.4 & 71.0 \\
\hline $0(a)$ & $-\infty$ & Unirradiated & 28.5 & 66.5 & $\infty$ & 34.9 & 71.6 \\
\hline $0(a)$ & - & Unirradiated & 28.0 & 65.9 & $-\infty$ & 34.9 & 69.4 \\
\hline $7.2 \times 10^{21(b)}$ & BMI 24-18 & As irradiated & 81.8 & 83.0 & 10.7 & 14.5 & 61.0 \\
\hline $5.5 \times 10^{21(c)}$ & BMI 24-18 & As irradiated & 80.0 & 84.0 & 13.2 & 16.4 & 60.0 \\
\hline $1.1 \times 10^{22(c)}$ & BMI 24-6 & As irradiated & 86.8 & 89.0 & 10.1 & 13.3 & 60.7 \\
\hline $8.7 \times 10^{21(b)}$ & BMI 24-6 & As irradiated & 85.3 & 87.5 & 9.0 & 11.9 & 60.7 \\
\hline $1.0 \times 10^{22(b)}$ & BMI 24-6 & $\begin{array}{l}\text { Irradiated and annealed } \\
\text { at } 1800 \mathrm{~F} 1 \mathrm{hr}\end{array}$ & 28.2 & 64.3 & 27.7 & 30.0 & 68.0 \\
\hline $5.5 \times 10^{21(c)}$ & BMI 24-18 & $\begin{array}{l}\text { Irradiated and annealed } \\
\text { at } 1800 \mathrm{~F} \mathrm{I} \mathrm{hr}\end{array}$ & 27.4 & 65.0 & 28.7 & 31.7 & 68.0 \\
\hline
\end{tabular}

(a) Tests made by Knolls Atomic Power Laboratory.

(b) Values based on $\mathrm{Fe}^{54} \rightarrow \mathrm{Mn}^{54}$ reaction.

(c) Values based on cycle-to-cycle determination of $\mathrm{Ni}^{58} \rightarrow \mathrm{Co}^{58}$ reaction. 


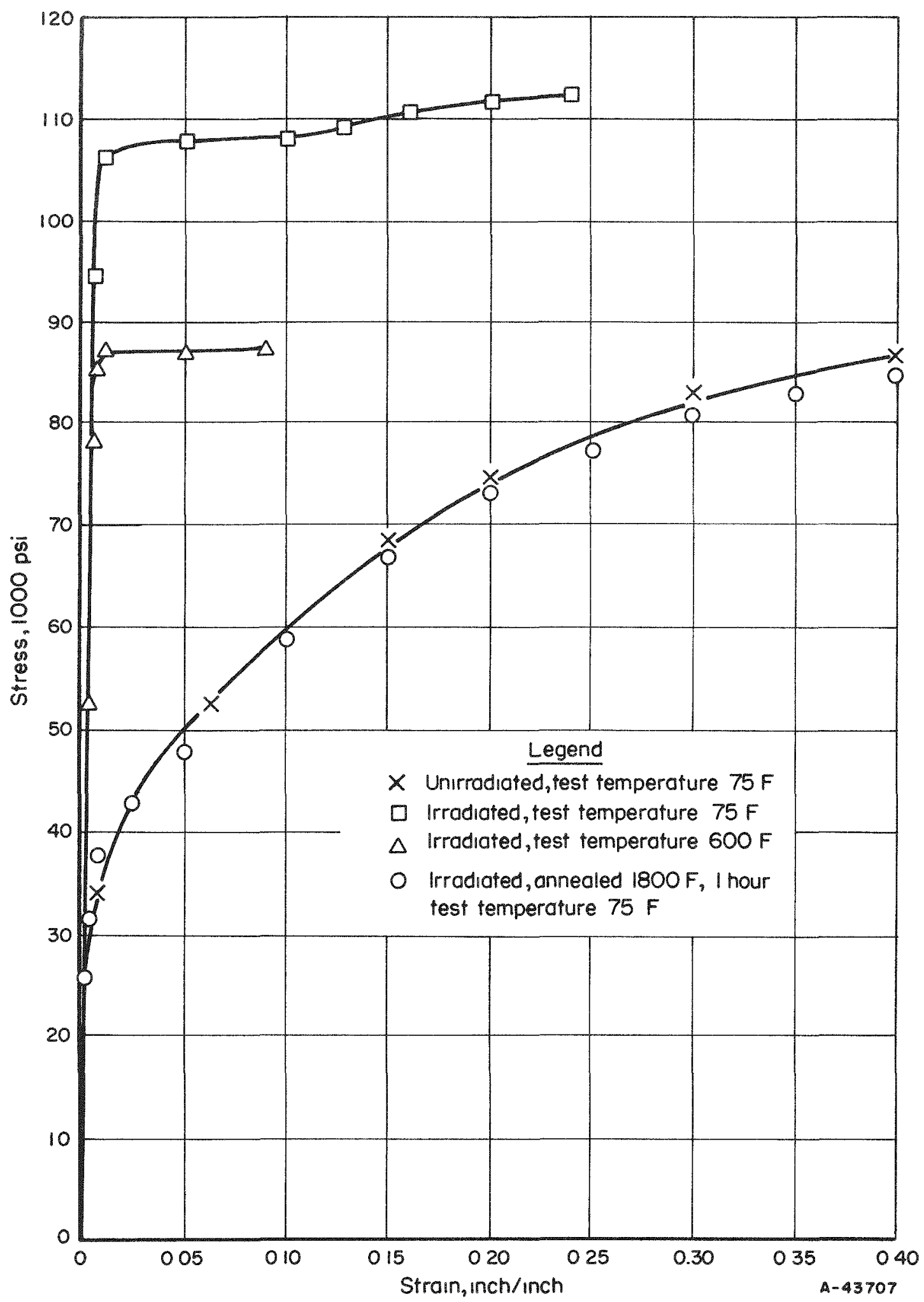

FIGURE 9. STRESS VERSUS STRAIN FOR AISI TYPE 347 STAINLESS STEEL BEFORE AND AFTER IRRADIATION TO 1. $1 \times 10^{22} \mathrm{nvi}$ 
The appearance of several tensile specimens after testing is shown in Figure 10. It was noted that all specimens exhibited typical cup-and-cone ductile-type fractures as shown by necking at the point of fracture. The black tenacious deposit appearing on the elevated-temperature tensile-test specimens is residue remaining from the glass-fiber tape used to fasten the thermocouple junctions to the specimen gage section and is not believed to have influenced the tensile properties.

Metallography and Hardness Studies

Metallographic examinations were performed upon fractured impact and subsize tensile specimens from Capsules BMI-24-14, BMI-24-6, and BMI-24-18, respectively. For comparison, several specimens of the unirradiated control material were similarly prepared and examined. Microstructures of both unirradiated and irradiated specimens are shown in Figures 11 and 12. Obvious differences among the microstructures of unirradiated, irradiated, and irradiated and annealed specimens were not observed. during optical examinations at magnifications up to 500X. There were also no obvious differences in microstructure between specimens irradiated to dosages of $6.5 \times 10^{21}$ and those ir radiated to dosages of about $1.1 \times 10^{22} \mathrm{nvt}$.

Hardness measurements were obtained upon all irradiated tensile specimens from Capsules BMI-24-6 and BMI-24-18 for comparison with preirradiation hardness data. The measurements were made with a Rockwell hardness tester upon the flat button head of each specimen. The preirradiation hardness value of the Type 347 stainless steel was 51.8 Rockwell $\mathrm{A}$, whereas the postirradiation hardness value was about 59.8. The hardness values increased approximately 8 Rockwell A numbers at both irradiation exposures to give an approximate 15 per cent increase. Thus, the additional exposure from $6.5 \times 10^{21}$ to $1.1 \times 10^{22}$ nvt produced no additional hardening in the Type 347 stainless steel, indicating that a hardness saturation had been reached at or prior to exposures or $6.5 \times 10^{21} \mathrm{nvt}$.

\section{Discussion and Conclusions}

The results of impact and tensile tests upon. AISI Type 347 stainless steel have been determined for exposures up to about $1.1 \times 10^{22}$ nvt. This level represents the highest exposures to date for which tensile properties of Type 347 stainless steel specimens have been reported. The impact strength of Type 347 stainless steel having an exposure of about $6.5 \times 10^{21}$ nvt was reduced by about 50 per cent at room temperature with a considerably greater reduction at liquid-nitrogen temperatures. The type of fracture produced at room temperature generally was a ductile-type fracture. The fracture produced at liquid-nitrogen test temperatures was a combination cleavage and shear types, which is more indicative of brittle fracture.

Tensile tests performed upon subsize specimens of Type 347 stainless steel showed increases of nearly 200 per cent in the 0.2 per cent offset yield values, and increases in the ultimate strength of about 25 per cent as a result of irradiation to $1.1 \times 10^{22}$ nvt. Conversely, very large decreases in total elongation were observed. The hardness of specimens irradiated to exposures of $6.5 \times 10^{21}$ increased approximately 


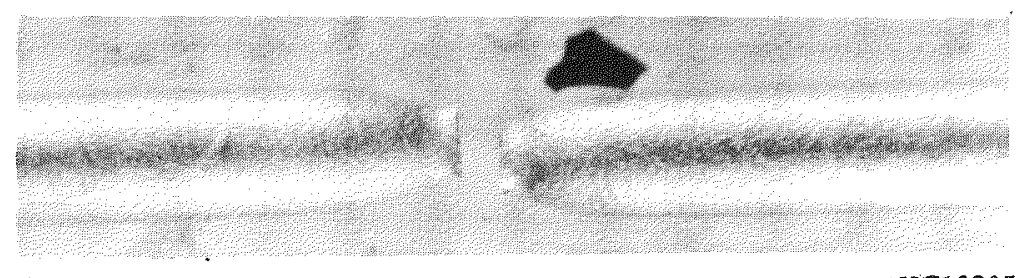

$4 \mathrm{X}$

HC10205

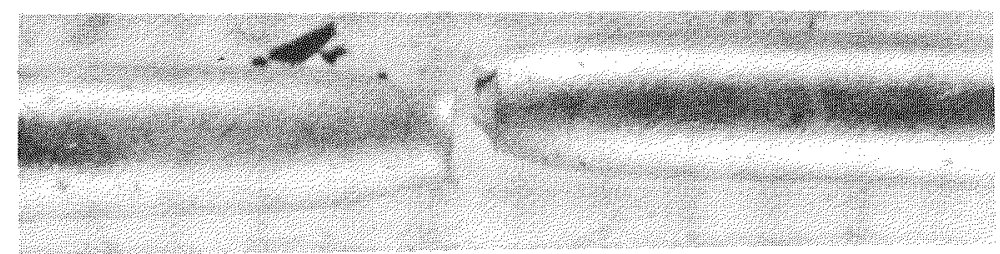

$4 \times$

HC1021J

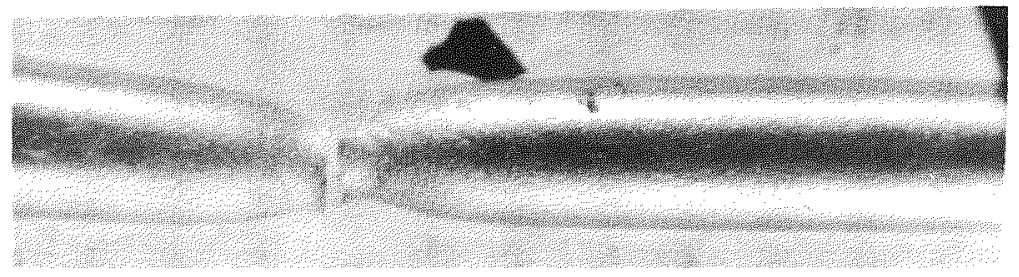

$4 X$

$\mathrm{HC10203}$

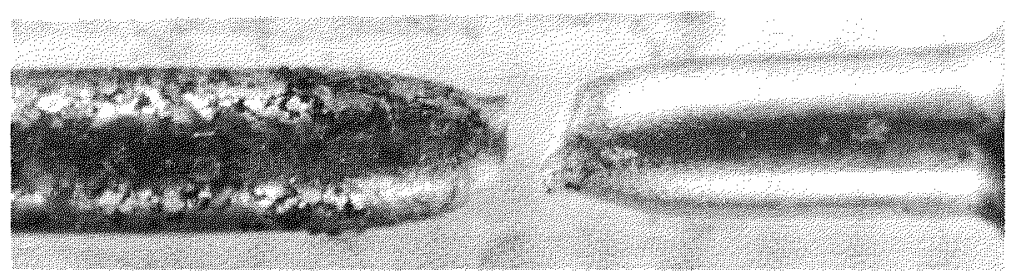

$4 \mathrm{X}$

HC10210

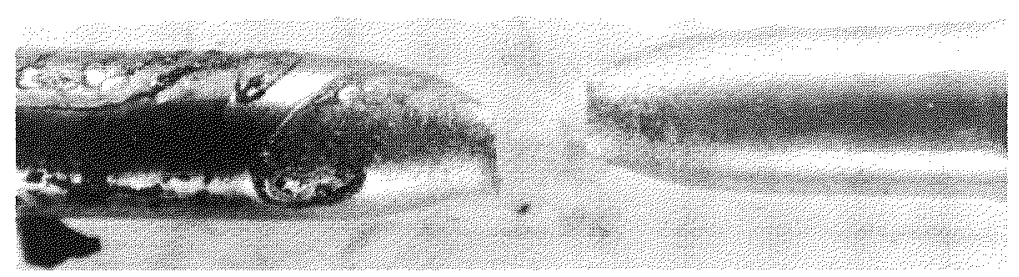

$4 \mathrm{X}$

HC10202

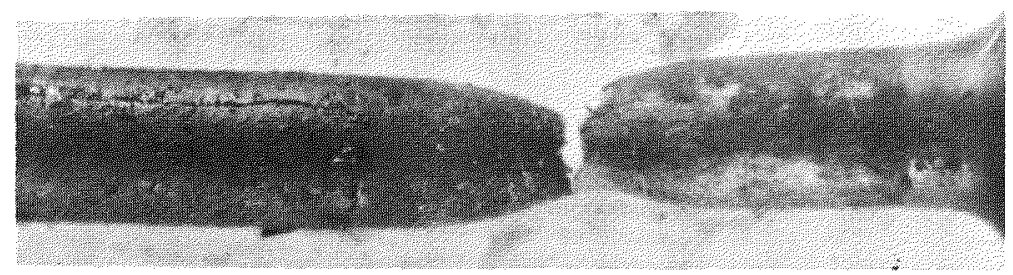

a. Unirradiated Control Tested at $20 \mathrm{C}$

b. Tested at $20 \mathrm{C}$ after Irradiation to 1.1. $\times 10^{22} \mathrm{NVT}$

Specimen 15, Capsule BMI-24-6, is shown.

c. Tested at $20 \mathrm{C}$ after Irradiation to $5.5 \times 10^{21} \mathrm{NVT}$

Specimen 22, Capsule BMI-24-18, is shown.

d. Tested at $600 \mathrm{~F}$ after Irradiation to $1.1 \times 10^{22} \mathrm{NVT}$

Specimen 13, Capsule BMI-24-6, is shown.

e. Tested at $600 \mathrm{~F}$ after Irradiation to $5.5 \times 10^{21} \mathrm{NVT}$

Specimen 21. Capsule BMI-24-18, is shown.

f. Tested at $600 \mathrm{~F}$ after Irradiation to $5.5 \times 10^{21} \mathrm{NVT}$ and Annealing $1 \mathrm{Hr}$ at $1800 \mathrm{~F}$

Spectmen 18, Capsule BMI-24-18, is shown. 


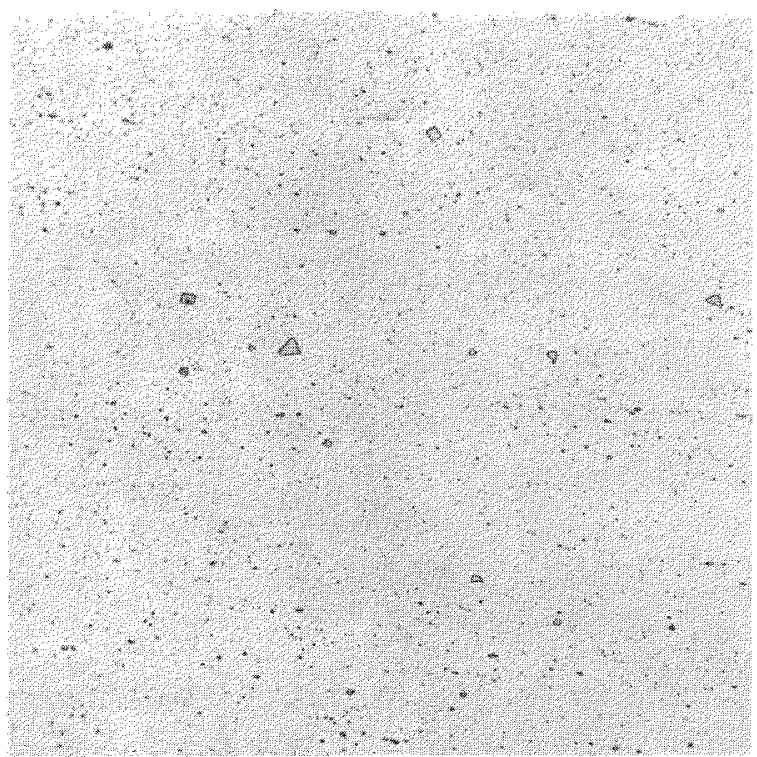

$250 \mathrm{X}$

As Polished

RM20413

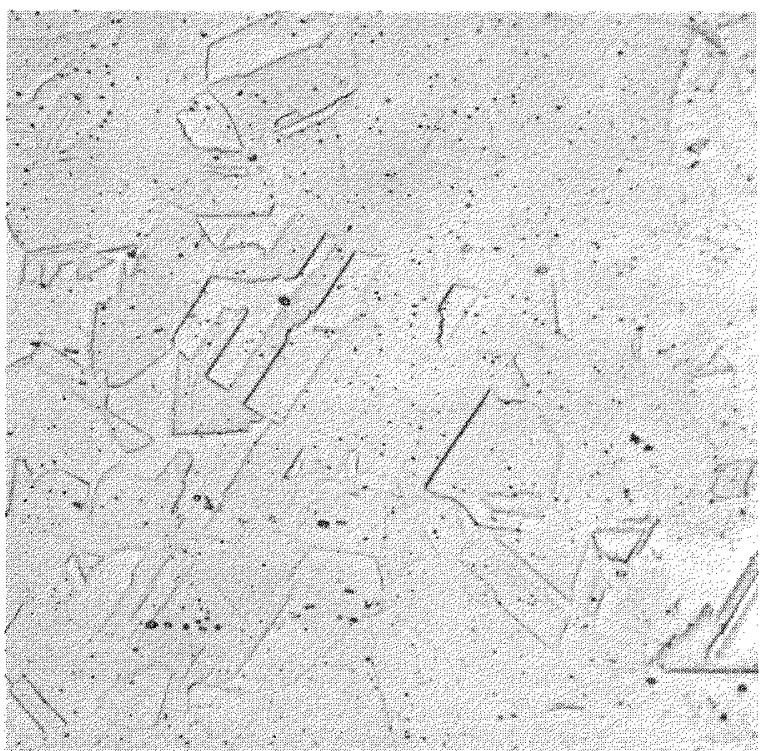

$500 \mathrm{X}$

Etched

RM20410

a. Typical Microstructure Before Irradiation

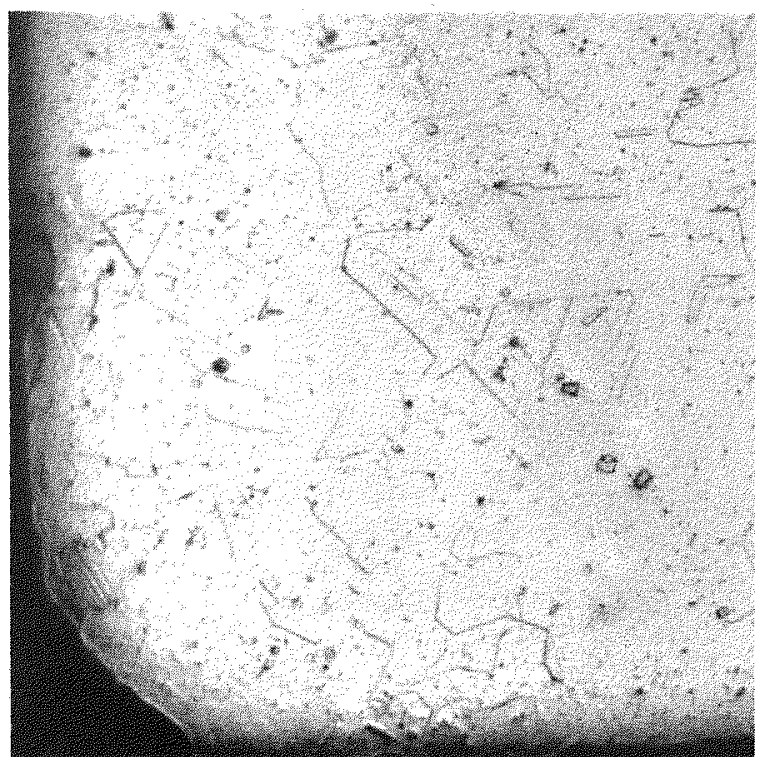

$500 \mathrm{x}$

Etched

HC5402

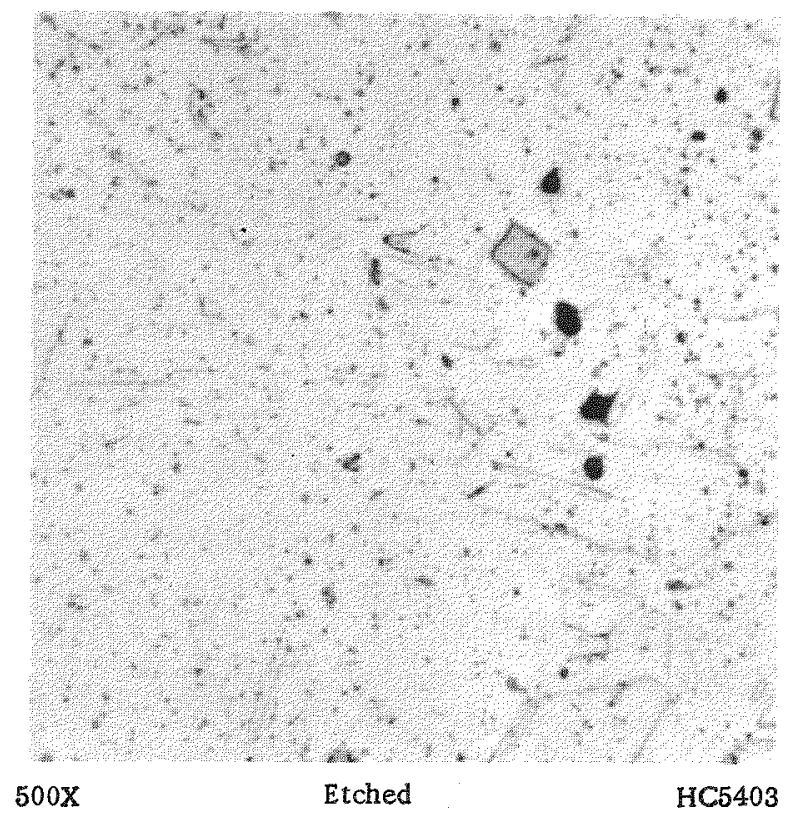

b. Structure after Irradiation to $5.7 \times 10^{21}$ at $120 \mathrm{~F}$

FIGURE 11. AISI TYPE 347 ST AINLESS STEEL BEFORE AND AFTER IRRADIATION

No obvious microstructural changes as a result of the irradiation were observed. 


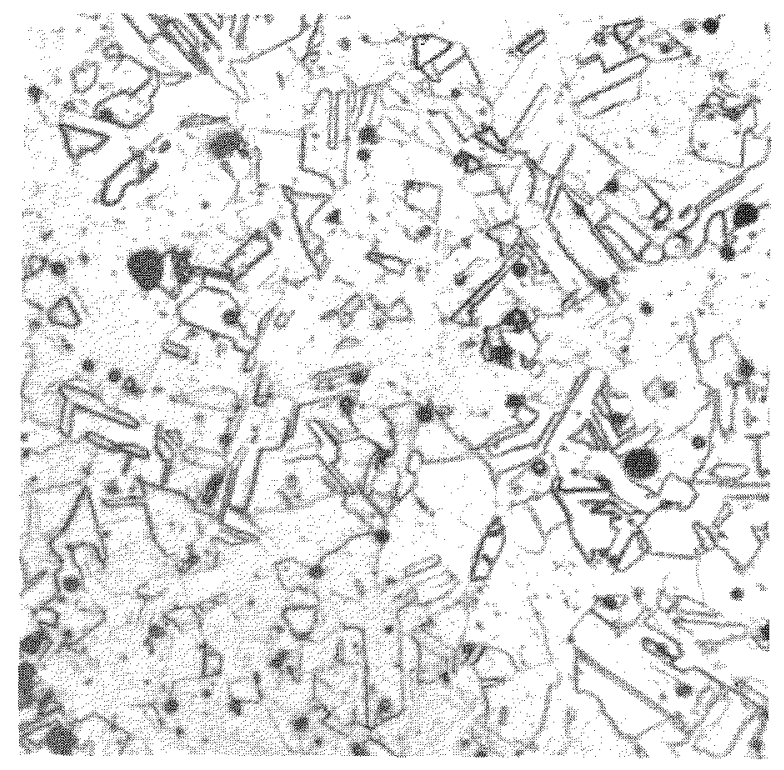

$250 \mathrm{X}$
Etched
$\mathrm{HC} 10243$

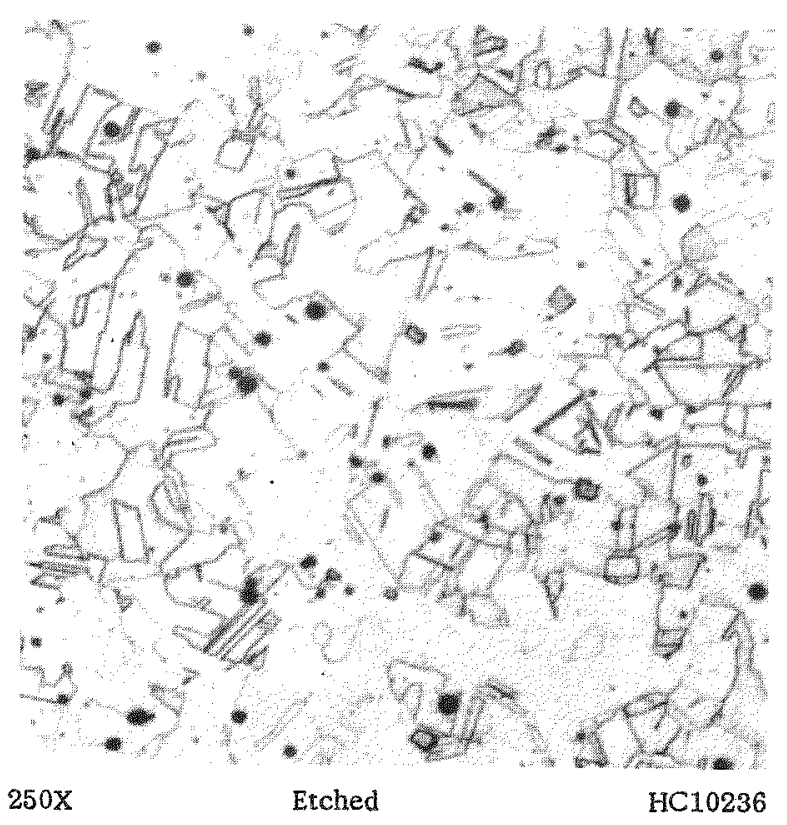

a. Irradiation Exposure of $6.5 \times 10^{21}$ NVT in Capsule BMI-24-18
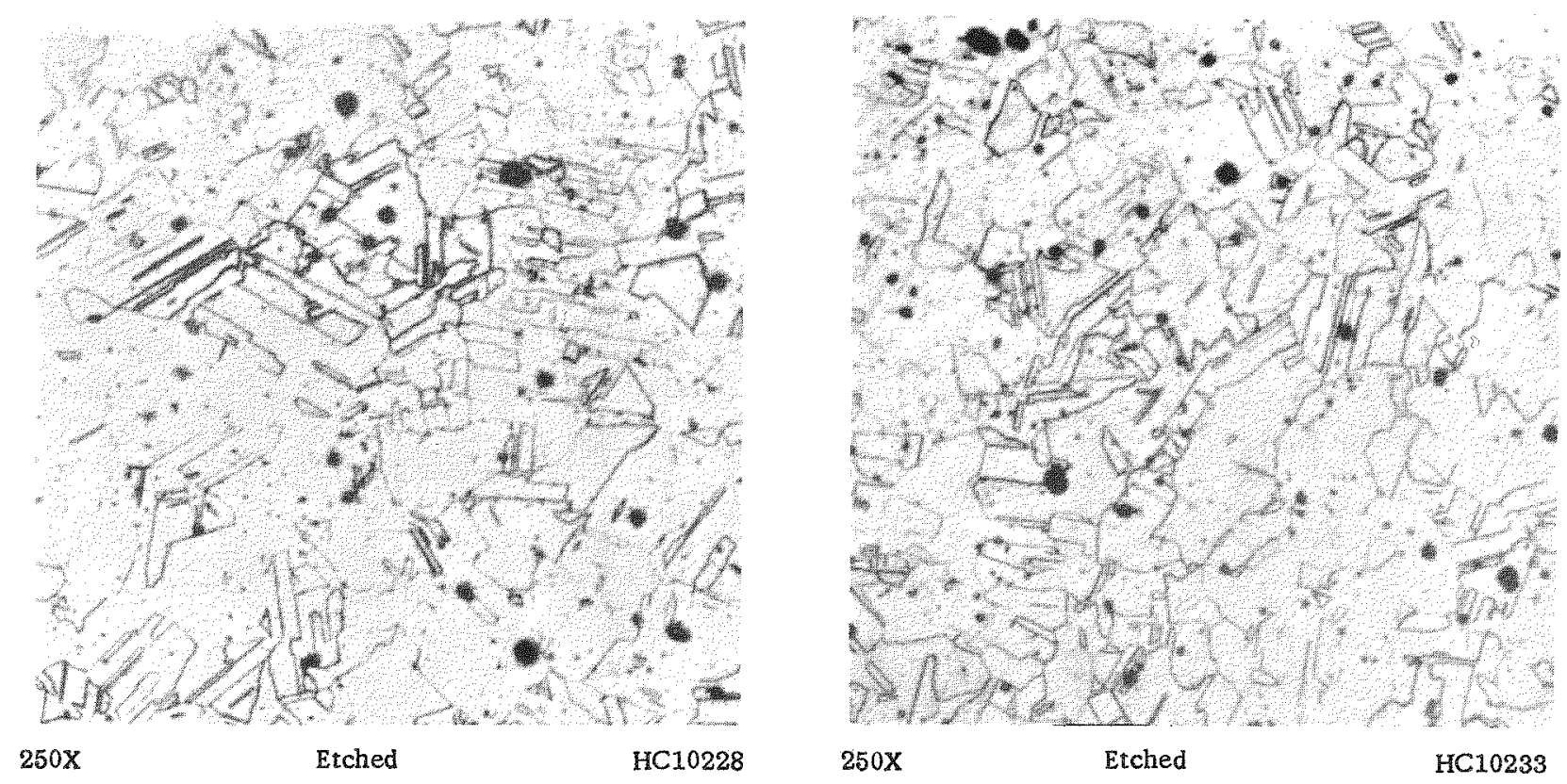

b. Irradiation Exposure of $1.1 \times 10^{22} \mathrm{NVT}$ in Capsule BMI $-24-6$

FIGURE 12. AS-IRRADIATED AND ANNEALED STRUCTURES OF TYPE 347 ST AINLESS STEEL SPECIMENS Specimens on the right were given a postirradiation anneal of $I \mathrm{hr} 2 \mathrm{t} 1800 \mathrm{~F}$. 
15 per cent over the hardness of similar unirradiated material, and it appeared that little change in hardness occurred as the result of increasing the neutron exposure from $6.5 \times 10^{21}$ to $1.1 \times 10^{22}$ nvt. These data, coupled with the results of tensile tests, indicate a trend of saturation of irradiation effects in AISI Type 347 stainless steel when ir radiated at process-water temperature, at a neutron exposure near $6.5 \times 10^{21}$ nvt or below.

The ability to remove the effects of neutron irradiation by postirradiation annealing (recovery of preirradiation mechanical properties and hardness) has been demonstrated. Annealing for $1 \mathrm{hr}$ at $1800 \mathrm{~F}$, in most cases, caused the recovery of the preirradiation properties of Type 347 stainless steel. Complete recovery of ductility was not achieved, however, particularly in the specimens that received the higher neutron exposure.

The microstructure of Type 347 stainless steel did not appear affected by differences in neutron exposure or by postirradiation annealing. This suggests that radiation damage in austenitic stainless steels does not produce gross microstructural changes. However, it is known $(8)$ that neutron bombardment produces a small degree of transformation to ferrite in Type 347 stainless steel. This slight amount of transformation causes an associated increase in ferrite which can be measured by magneticsusceptibility techniques. The small amount of ferrite produced in Type 347 stainles $s$ steel might contribute to the greatly reduced ductility of this steel when subjected to impact testing at $-196 \mathrm{C}$. It may also be possible to observe the changes in ferrite content by electron microscopy.

The capsules that have been examined and tested to date constitute about one-fourth of the surveillance program both in number and total neutron exposure. The remaining capsules will continue to be irradiated in the ETR and will be removed from the reactor at selected intervals for examination. The possibility of saturation of irradiation effects and changes in properties due to transmuted impurities in Type 347 stainless steel will be studied during examinations of specimens having higher fast-neutron dosages.

\title{
POSTIRRADIATION STUDIES OF SECTIONS OF THE ETR J-10 LOOP
}

\author{
Description and History of the J-10 Loop
}

The ETR contains facilities to accommodate several special test loops which provide special temperature, pressure, and atmospheric conditions for irradiation testing, according to specific requirements of the various reactor customers. Such a test loop was recently removed from the J-10 position of the ETR after a tenure of approximately 17 months. This loop consisted of two basic capsules or tubes, an inner tube containing test specimens in a pressurized-water or steam atmosphere, and an outer surrounding tube or jacket separated from the inner tube by a helium gas annulus. The outside of the outer tube made contact with reactor process water. The J-10 test loop was placed in service in the ETR in October, 1959, and was removed from the ETR on March 16, 1961. During this time the loop was exposed to approximately 222 effective full-power days $(\sim 38,800$ megawatt-days) at an estimated computed maximum flux (above $1 \mathrm{Mev}$ ) of

$3.8 \times 10^{14} \mathrm{nv}$. A résumé of the operating history of the loop is included in Table 12. 
A 36-in. - long section corresponding to the active fuel core was removed from both inner and outer loop sections and shipped to the Battelle Hot Cell Facility for postirradiation. examination. Details of the examination and the results are reported in this section.

TABLE 12, OPERATING HISTORY OF THE J-10 PRESSURE LOOP DURING IRRADIATION FOR 38,794 MEGAWATT -DAYS IN THE ETR FOR A TOTAL ACCUMULATED FAST-NEUTRON ( $>1 \mathrm{MEV})$ EXPOSURE OF $7.15 \times 10^{221} \mathrm{NVT}(9)$

\begin{tabular}{|c|c|c|c|c|c|}
\hline \multicolumn{6}{|c|}{ Operating Conditions } \\
\hline & & \multicolumn{3}{|c|}{ Design } & Actual \\
\hline \multicolumn{3}{|c|}{ Pressure, psig } & 2,500 & & 2,200 \\
\hline \multicolumn{3}{|c|}{ Pressure Stress, psi } & 14,100 & & 12,400 \\
\hline \multicolumn{3}{|c|}{ Gamma Heat, w per $g$, peak } & 35 & & 25 \\
\hline \multicolumn{3}{|c|}{ Water Inlet Temperature, $F$} & 600 & & $450-500$ \\
\hline \multicolumn{3}{|c|}{ Wall $\Delta \mathrm{T}, \mathrm{F}$} & 268 & & 191 \\
\hline \multicolumn{3}{|c|}{ Maximum Wall Temperature, $F$} & 898 & & $\sim 700$ \\
\hline \multicolumn{3}{|c|}{ Thermal Stress, psi } & 67,200 & & 48,000 \\
\hline \multicolumn{3}{|c|}{ Wall Thickness, in, } & 0.182 & & 0.188 \\
\hline \multicolumn{3}{|c|}{ Yield Strength, psi } & 30,000 & $70 \mathrm{~F})$ & $62,500($ at $70 F)$ \\
\hline \multicolumn{3}{|c|}{ Ultimate Strength, psi } & 75,000 & $70 \mathrm{~F})$ & $92,600$ (at $70 \mathrm{~F})$ \\
\hline \multicolumn{6}{|c|}{ Exposure } \\
\hline Cycle & Megawatt-Days & Report & Cycle & Megawatt-Days & Report \\
\hline 22 & 595 & IDO-16595 & 29 & 2,129 & IDO -16619 \\
\hline 23 & 1,662 & IDO- -16581 & 30 & 3,364 & IDO-16627 \\
\hline 24 & 975 & IDO-16585 & 31 & 1,358 & IDO- 16641 \\
\hline 25 & 1,648 & IDO- 16589 & 32 & 5,310 & IDO-16645 \\
\hline 26 & 3,063 & IDO -16598 & 33 & 5,086 & IDO - 16649 \\
\hline 27 & 4,467 & IDO- 16603 & 34 & 3,499 & IDO-16676 \\
\hline 28 & 4,134 & IDO- 16618 & 35 & 1,505 & IDO -16680 \\
\hline
\end{tabular}

The pressure tube was fabricated" by Thompson Products (Jet Division) from a forging produced by McInnes Steel Company. The initial billet, which was 6 in. in diameter, was heated to $2250 \mathrm{~F}$ and reduced by forging to $3 \mathrm{in}$. in diameter and air cooled. The forging was then rough machined, stress-relief annealed for $1 \mathrm{hr}$ at $1000 \mathrm{~F}$, and water quenched. The core section of the pressure tube was milled from the billet at this point. Tensile properties of specimens removed from opposite ends of the billet are given in Table 13, along with chemical analyses of the finished billet.

The gas jacket was forged by Ladish. The forgings were heat treated for $1 \mathrm{hr}$ at $1950 \mathrm{~F}$ and water quenched. The forging was then reheated to $1000 \mathrm{~F}$ for $1 \mathrm{hr}$ and water quenched. Tensile properties of the gas jacket, as determined by tests of material removed from opposite ends of the gas jacket are also given in Table 13. The information indicates that the compositions and fabrication conditions of both the pressure tube and the gas jacket were somewhat similar, although forging was accomplished at a higher temperature for the pressure tube. The tensile strength of the inner pressure tube was slightly higher, and the 0.2 per cent offset, yield strength was appreciably higher than that of the gas jacket. The ductility of both loop sections was approximately equal in the preirradiation condition.

"Detalls of the fabrication history of the pressure tube and jacket were provided by Mr. C. D. Sellers, Bettis Atomic Power Laboratory, Westinghouse Electric Corporation. 
TABLE 13. COMPOSITION AND PROPERTIES OF J-10 GAS JACKET AND PRESSURE TUBE

\begin{tabular}{|c|c|c|}
\hline & Outer Loop, or Gas Jacket(a) & Inner Loop, or Pressure Tube (b) \\
\hline \multicolumn{3}{|l|}{ Composition, w/o } \\
\hline Carbon & 0.035 & 0.045 \\
\hline Manganese & 1.59 & 1.60 \\
\hline Phosphorus & 0.013 & 0.025 \\
\hline Sulfur & 0.018 & 0.015 \\
\hline silicon & 0.56 & 0.42 \\
\hline Nickel & 10.76 & 10.30 \\
\hline Chromium & 18.66 & 19.85 \\
\hline Niobium & 0.84 & .81 \\
\hline Tantalum & 0.10 & -- \\
\hline Tensile Strength, psí & $84,500-87,400$ & 91,300 to 93,000 \\
\hline $0.2 \mathrm{Per}$ Cent Offset Yield Strength, psi & $36,300-43,300$ & $53,500-60,700$ \\
\hline Elongation, per cent & $53.0-57.0$ & $53.0-61.4$ \\
\hline Reduction in Area, per cent & $73.0-75.0$ & $68.0-72.1$ \\
\hline
\end{tabular}

(a) Composition furnished by Ladish of the billet which supplied the gas jacket. Mechanical properties were obtained on billets from opposite ends of the forging following $1000 \mathrm{~F}$ stress-relief heat treatment.

(b) Composition furnished by Thompson-Ramo-Wooldridge on finished component. Mechanical properties were obtained on billets from large and small ends of forging following rough machining and $1000 \mathrm{~F}$ stress-relief hot treatment.

A list of the pertinent design and actual operating parameters associated with the $\mathrm{J}-10$ tube was given in Table $12(9)$. The list was composed by WAPD personnel from data supplied in part by the Phillips Petroleum Company ETR staff. The actual operating conditions were somewhat less stringent than intended; however, the estimated fast-flux levels and total exposures were in excellent agreement with postirradiation data obtained at Battelle with maximum-exposure samples. A calculated wall-temperature profile versus the axial core position is given in Figure 13, as supplied by Bettis personnel. Figure 13 also gives the relative vertical position of all of the specimens removed for testing from the $J-10$ pressure tube.

\section{Postirradiation Studies of $\mathrm{J}-10$ Specimens}

A schematic of the inner pressure tube and outer jacket of the $\mathrm{J}-10$ loop is shown in Figure 14. The section of the tube which passed through the reactor core and was removed for testing is identified in the drawings. Both inner and outer loop sections arrived at Battelle in two pieces, a 19-in.-1ong top and 17-in. -long bottom section. The pressure tube was $2.200 \mathrm{in}$. in $O D$ by $0.188 \mathrm{in}$. thick and the outer jacket was $2.450 \mathrm{in.}$ in $O D$ by $0.092 \mathrm{in}$. thick. The north axis of the loop was identified by a 1/4-in. diameter hole drilled near the top of the upper sections and bottom of the lower sections.

Examination of the tubes was initiated shortly after they were received at the Battelle Hot-Cell Facility. The four sections were viewed under a stereomacroscope and it was noted at this time that the surface of the inner loop, in particular, contained mottled areas indicative of selective oxidation. Temperature measurements obtained on 


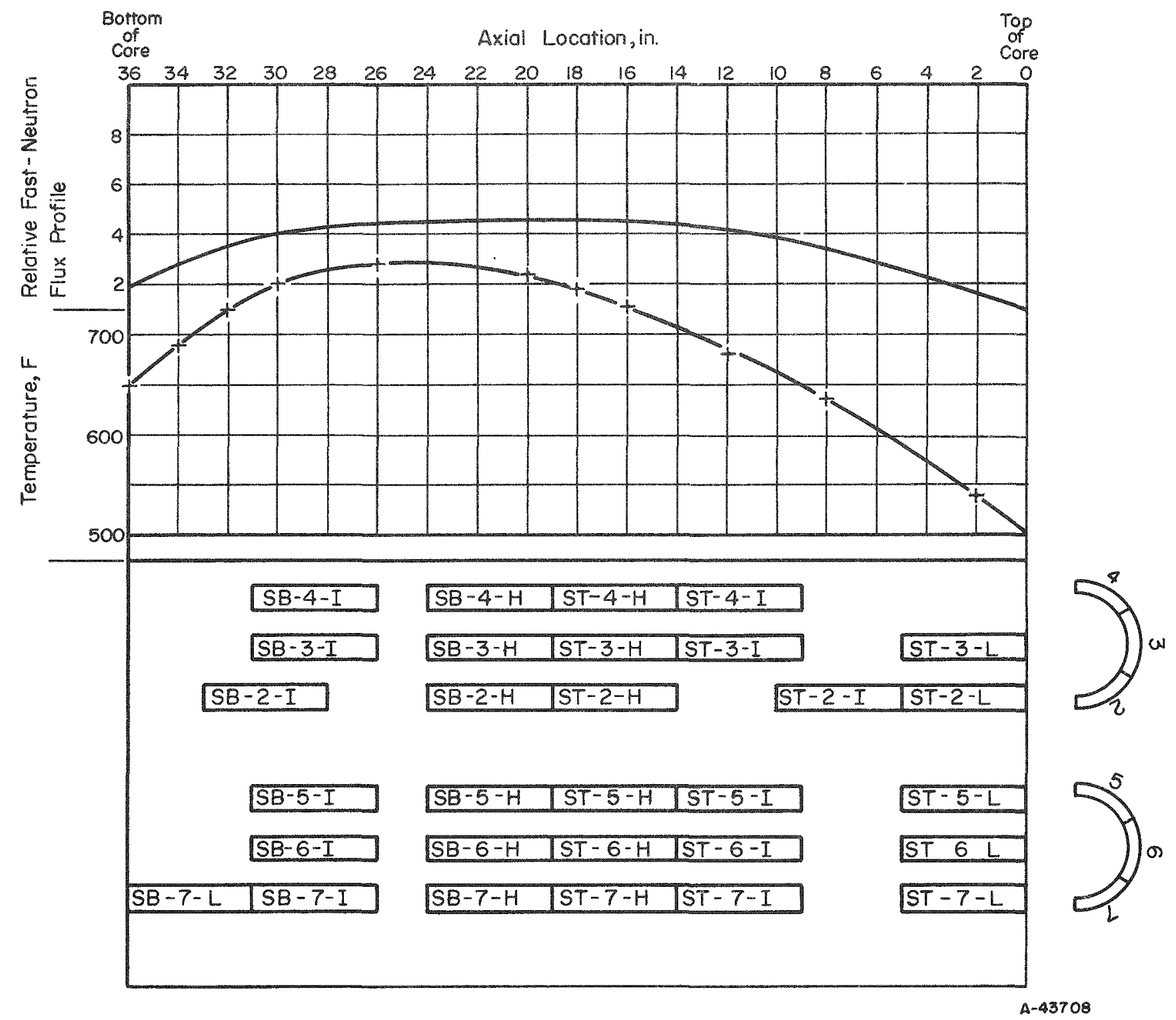

FIGURE 13. TEMPERATURE-FLUX PROFILE OF J-10 PRESSURE TUBE SHOWING SPECIMEN LOCATIONS 

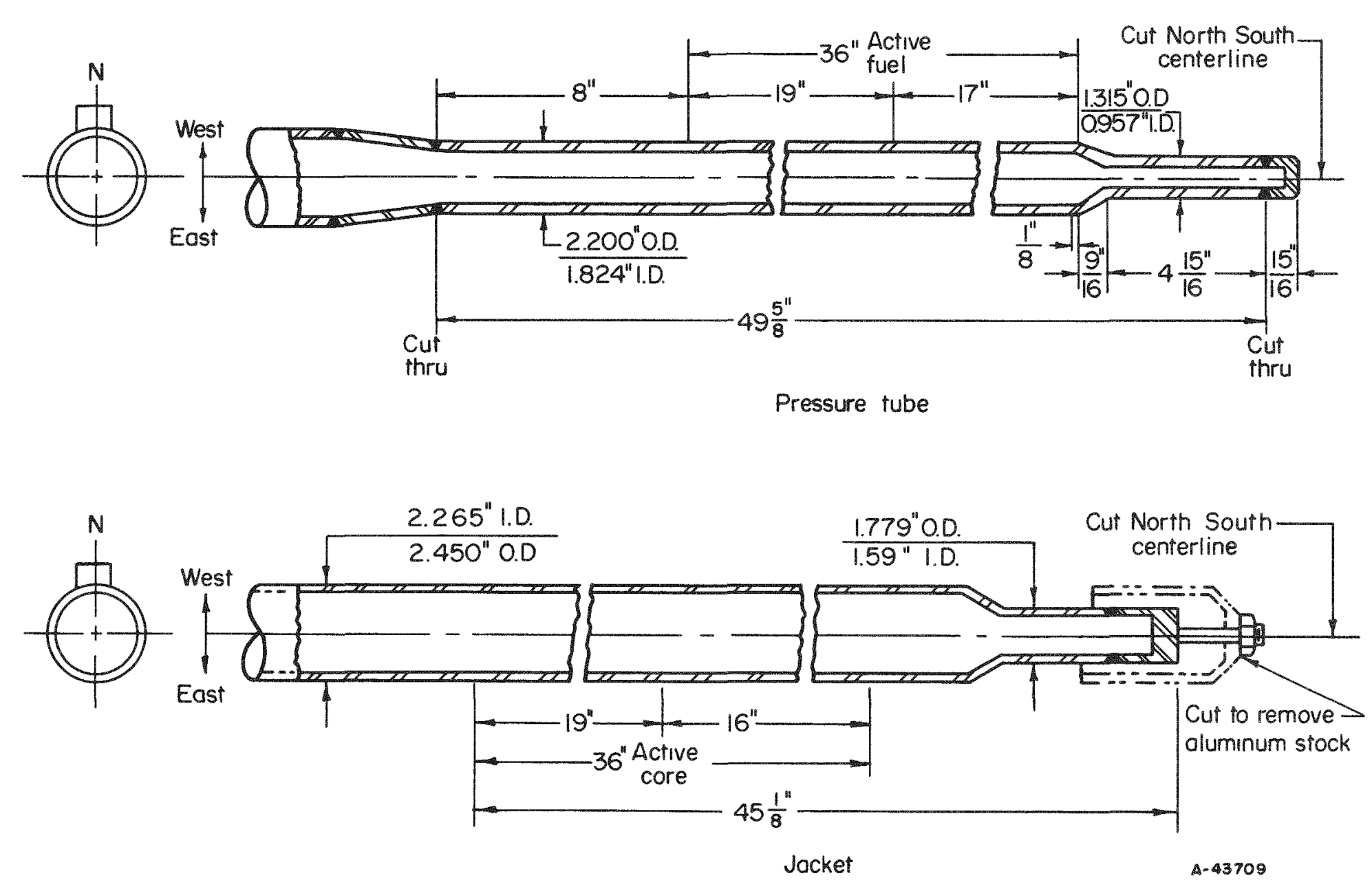

FIGURE 14. SCHEMATIC SECTION OF J-10 PRESSURE TUBE AND JACKET 
the surface of the inner loop showed a $10 \mathrm{~F}$ higher temperature than ambient cell temperature, due to residual gamma heating. The temperature of the outer jacket was not measured.

Sectioning of J-10 Tubes

Tensile specimens were prepared from one half of the J-10 pressure tube and the gas jacket, and the remaining loop sections were retained for subsequent examinations. The entire inner tube was later sectioned for preparation of a duplicate set of specimens. In order to study the effect of various neutron exposures, sections were cut into strips approximately $1.15 \mathrm{in}$. wide and scanned to measure the intensity of emitted gamma rays as a function of position along the length of the section.

\section{Gamma Scan of Loop Strips}

The strips, measuring approximately $1.15 \mathrm{in.}$ in width, were subjected to scanning by a gamma-ray spectrometer in order to aid in selecting areas of low, intermediate, and high neutron exposure for testing. The relative intensity of the gamma radiation emitted by the strips was determined from gamma-ray spectrographic traces made by adjusting the spectrometer for maximum activity response from manganese-54 standards, and performing physical scans on strips at these energy settings.

Scans were made on 12 strips from the inner loop, including 6 from the top and 6 from the bottom. Strip 2 supplied five of the initial six inner J-10 loop specimens tested, namely $S T-2-L, S T-2-I$, and $S T-2-H$, and $S B-2-H$ and $S B-2-I$. The sixth initial inner loop specimen. was supplied from Strip 3. Strip 7 supplied all six of the duplicate test specimens. Plots of the relative gamma intensity as determined from the individual inner loop strips are shown in Figures 15, 16, and 17. Plots of the two strips from which outer loop specimens were prepared are shown in Figures 18 and 19.

\section{Dosimetry Results}

The fast-neutron exposures to which sections of the J-10 loop were exposed were determined by measurement of the manganese-54 in filings removed from the fracture area of each of the 18 irradiated specimens. Results of the analyses are shown in Table 14. The data have been treated to include the decay of manganese-54 between Cycles 22 and 35 , giving an effective irradiation time of 171.1 days. The technique by which the analyses were performed is discussed elsewhere in the report. Factors and constants used in calculating the fast-neutron flux were:

(1) 0.054 barn cross section for the $\mathrm{Fe}^{54}(\mathrm{n}, \mathrm{p}) \mathrm{Mn}^{54}$ reaction

(2) 5.9 per cent isotopic abundance of iron -54

(3) $68 \mathrm{w} / 0$ iron in the Type 347 stainless steel

(4) Flux $>1 \mathrm{Mev}$ was equal to 0.692 total fast flux

(5) 300-day half-life for manganese-54. 


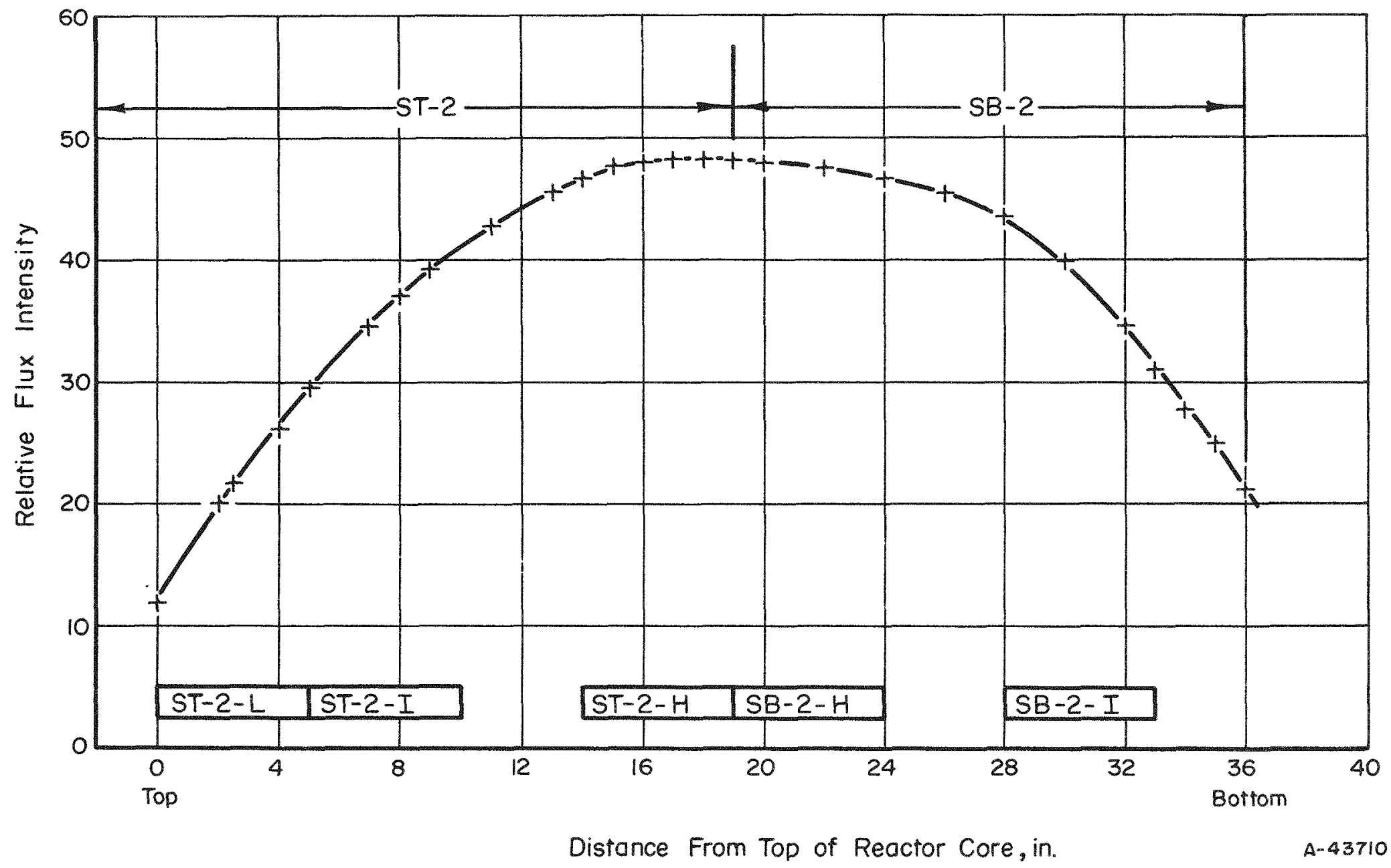

FIGURE 15. FAST-FLUX PROFILE DETERMINED BY GAMMA SCAN OF J-2 INNER LOOP SECTIONS ST-2 AND SB-2 As indicated, these strips supplied five of the six inner loop specimens 


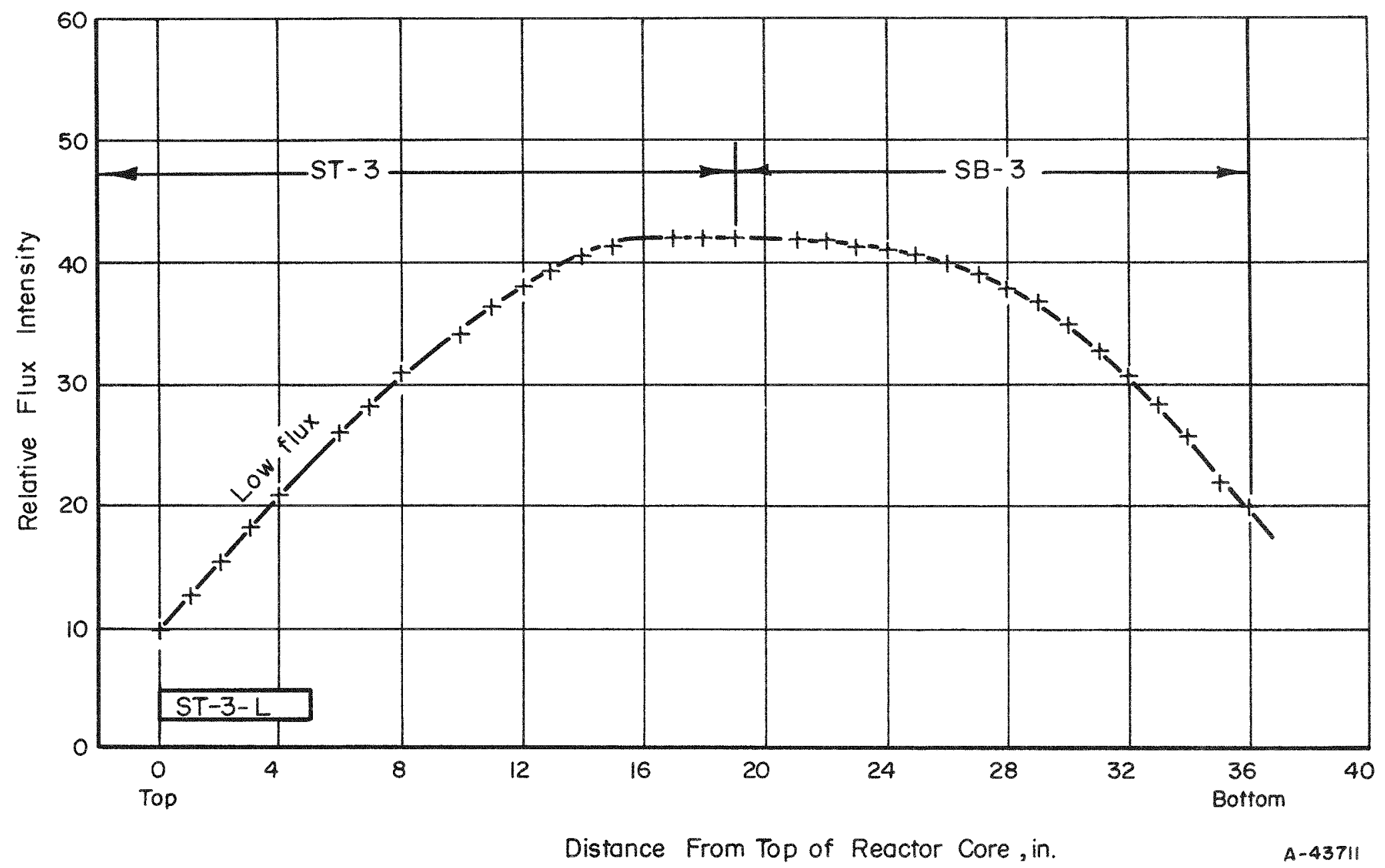

FIGURE 16. FAST-FLUX PROFILE DETERMINED BY GAMMA SCAN OF J-10 INNER LOOP SECTIONS ST- 3 AND SB-3

Specimen ST-3-L was taken from the top section. 


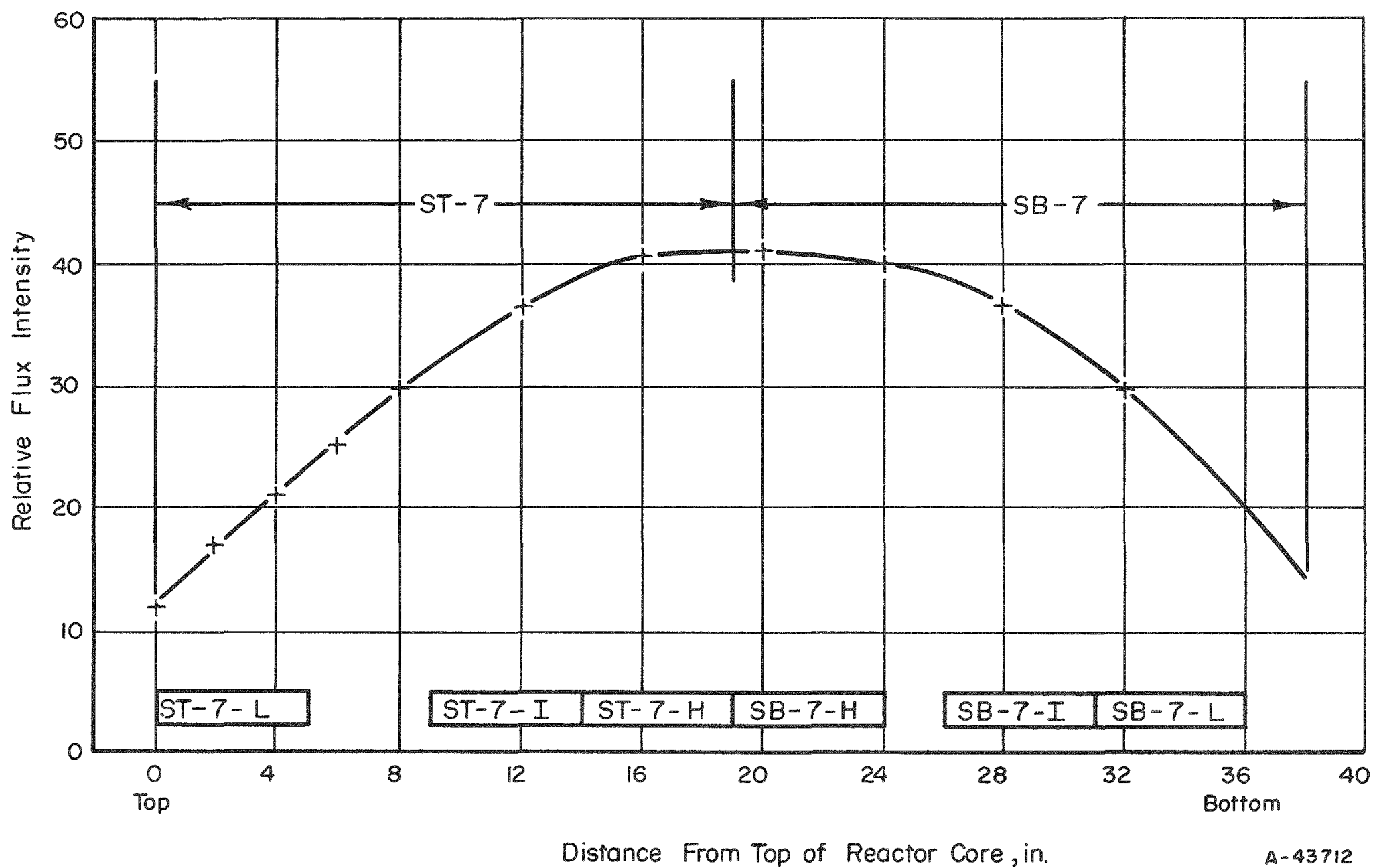

FIGURE 17. FAST-FLUX PROFILE DETERMINED BY GAMMA SCAN OF J-10 INNER LOOP SECTIONS ST-7 AND SB-7

As shown, six specimens were machined from these strips. 


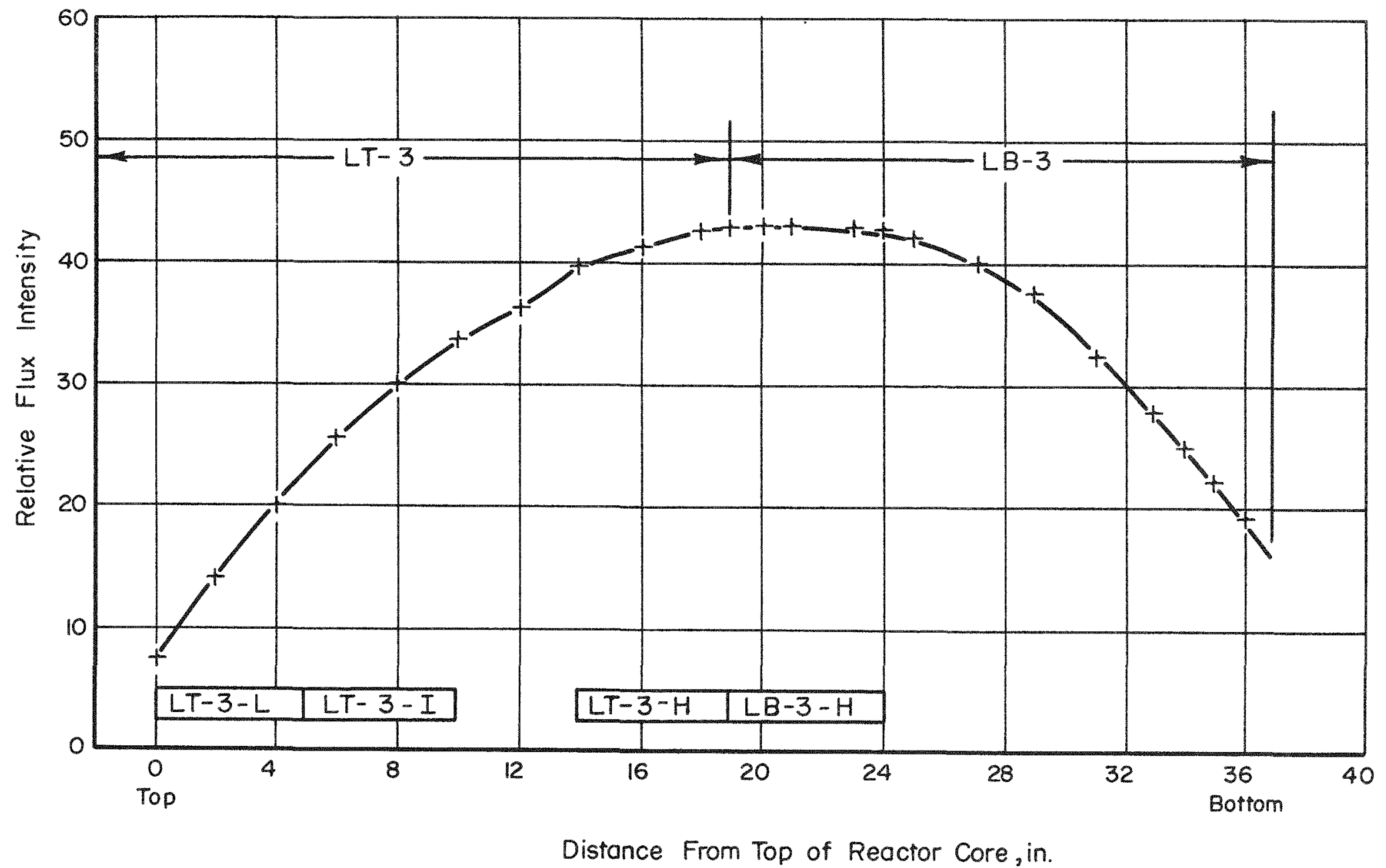

FIGURE 18. FAST-FLUX PROFILE DETERMINED BY GAMMA SCAN OF J-10 OUTER LOOP SECTIONS LT-3 AND LB-3

As indicated, four gas jacket specimens were machined from these strips. 


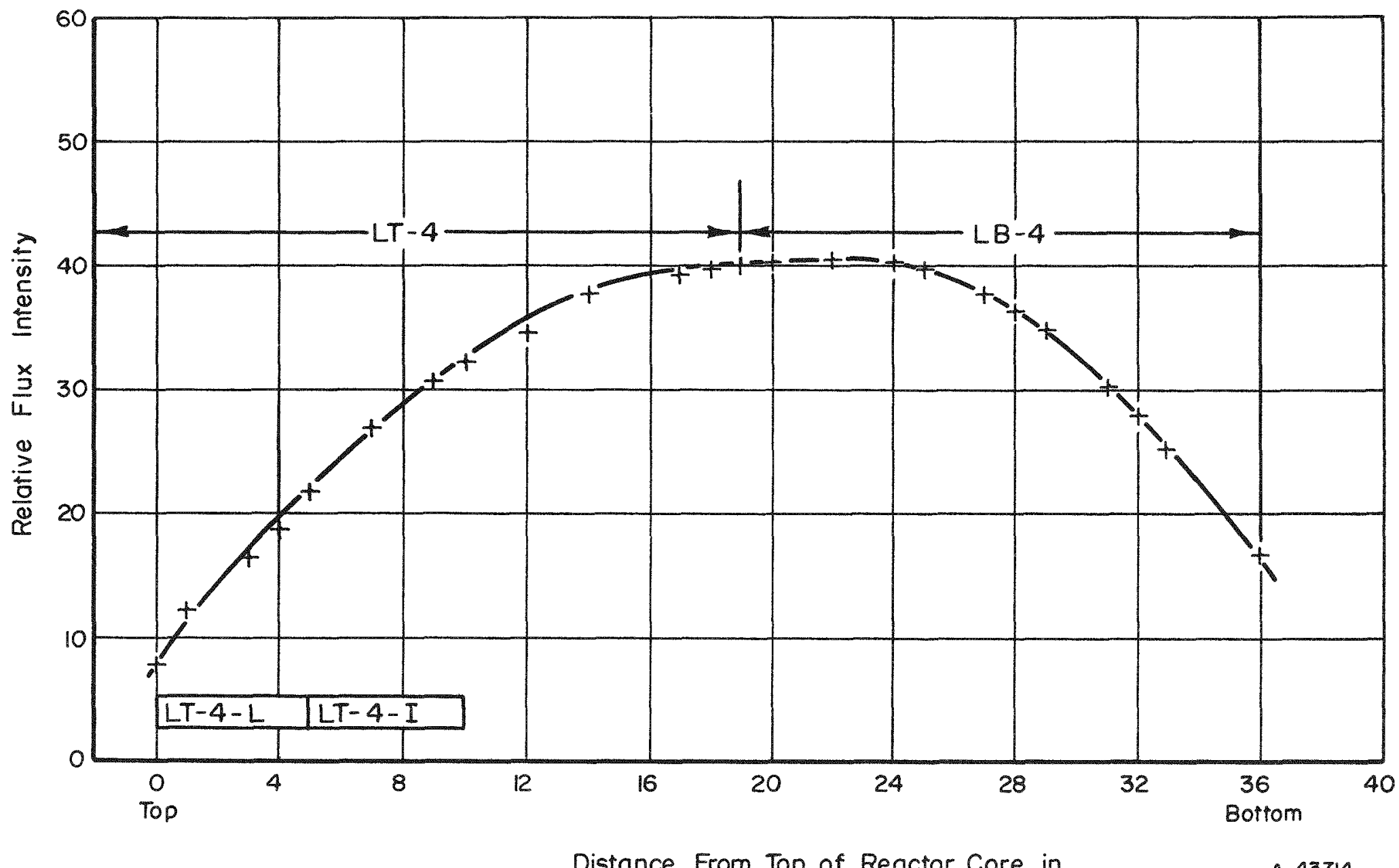

FIGURE 19. FAST-FLUX PROFILE DETERMINED BY GAMMA SCAN OF J-10 OUTER LOOP SECTIONS LT-4 AND LB-4

As shown, two specimens were obtained from the top section. 
TABLE 14. TEST RESULTS OBTAINEO ON IRRADIATED TENSILE SPECIMENS MACHINED FROM SECTIONS OF THE J 10 LOOP

\begin{tabular}{|c|c|c|c|c|c|c|c|c|}
\hline \multirow[b]{2}{*}{ Specimen } & \multirow[t]{2}{*}{$\begin{array}{c}\text { Approximate } \\
\text { Peak } \\
\text { Irradiation } \\
\text { Test } \\
\text { Temperature, } \\
\text { F }\end{array}$} & \multicolumn{2}{|c|}{$\begin{array}{c}\text { Fast-Neutron } \\
(>1 \text { Mey) } \\
\text { Exposure (a) }\end{array}$} & \multirow{2}{*}{$\begin{array}{c}\text { Temperature } \\
\text { of Test. F }\end{array}$} & \multirow[t]{2}{*}{$\begin{array}{c}0.2 \text { Per } \\
\text { Cent offset } \\
\text { Yield } \\
\text { strength, } \\
10^{3} \text { psi }\end{array}$} & \multirow{2}{*}{$\begin{array}{c}\text { Ultimate } \\
\text { Tensile } \\
\text { Strength, } \\
10^{3} \mathrm{psi}\end{array}$} & \multirow{2}{*}{$\begin{array}{c}\text { Total } \\
\text { Elongation, } \\
\text { per cent, } \\
\text { in } 2 \text { In. }\end{array}$} & \multirow{2}{*}{$\begin{array}{l}\text { Reduction } \\
\text { of Area, } \\
\text { per cent }\end{array}$} \\
\hline & & $10^{14} \mathrm{NV}$ & $10^{21} \mathrm{NVT}$ & & & & & \\
\hline \multicolumn{9}{|c|}{ Inner Loop, Initial Tests } \\
\hline$S T-3-L$ & 510 & 1.0 & 1.9 & 75 & 132.0 & 132.0 & 4.25 & 53.5 \\
\hline$S T-2-1$ & 625 & 2.0 & 3.9 & 75 & 145.0 & 145.0 & 6.50 & 54.5 \\
\hline $\mathrm{ST}-2-\mathrm{H}$ & 735 & 3.7 & 7.1 & 75 & 149.0 & 149.0 & 10.30 & 58.2 \\
\hline$S T=2 * \mathrm{~L}$ & 540 & 1.1 & 2.1 & 750 & 103.0 & 103.0 & 4.50 & 42.7 \\
\hline$S B-2-1$ & 740 & 2.7 & 5.1 & 750 & 115.0 & 115.0 & 1.50 & 40.8 \\
\hline $\mathrm{SB}-2-\mathrm{H}$ & 760 & 3.6 & 6.9 & 750 & 120.0 & 120.0 & 2.50 & 50.5 \\
\hline Control(b) & $-\infty$ & -- & $-\infty$ & 70 & $52.5-60.7$ & $91.3-93$ & $53-61$ & $68-72$ \\
\hline Handbook data $(c)$ & $-\infty$ & - & $\cdots$ & 750 & $40-50$ & $70-80$ & $45-50$ & - - \\
\hline \multicolumn{9}{|c|}{ Inner Loop, Duplicare Tests } \\
\hline$S T=7 \times L$ & 540 & 0.87 & 1.7 & 75 & 130.0 & 134.0 & 6.5 & 59.1 \\
\hline$S T-7-I$ & 675 & 2.9 & 5.57 & 75 & 139.5 & 144.8 & 10.6 & 59.8 \\
\hline$S T \sim 7-H^{(d)}$ & 735 & 1.7 & 3.26 & 75 & $14.3,0$ & 147.0 & 9.4 & 61.5 \\
\hline$S B \approx 7-L$ & 700 & 1.2 & 2.3 & 750 & 115.3 & 115.3 & 4.2 & 64.0 \\
\hline$S B-7-1$ & 760 & 1.9 & 3.65 & 750 & 123.0 & 123.5 & 4.2 & 45.5 \\
\hline $\mathrm{SB}-7 \sim \mathrm{H}$ & 760 & 3.4 & 6.5 & 750 & 125.4 & 125.8 & 4.1 & 40.5 \\
\hline \multicolumn{9}{|c|}{ Outer Loop } \\
\hline$L T=-4-L$ & 120 & 0.91 & 1.8 & 75 & 100.0 & 103.5 & 31.5 & 54.0 \\
\hline$L T-4-I$ & 120 & 1.8 & 3.5 & 75 & 95.2 & 101.3 & 26.0 & 57.0 \\
\hline $\mathrm{LB}=3 \sim \mathrm{H}$ & 120 & 3.4 & 6.5 & 75 & 102.5 & 108.0 & 25.0 & 60.5 \\
\hline$L T-3-L$ & 120 & 3.1 & 2.0 & 750 & 62.5 & 66.7 & 13.3 & 54.0 \\
\hline$L T-3-1$ & 120 & 2.4 & 4.5 & 750 & 65.4 & 69.3 & 11.4 & 54.6 \\
\hline$L T-3-H(\Theta)$ & 120 & 2.7 & 5.1 & 600 & 71.8 & 73.3 & 12.5 & 48.3 \\
\hline Control $1^{(f)}$ & - & $\cdots$ & $-\infty$ & 75 & 46.8 & 99.7 & 50.4 & 61.8 \\
\hline Control $2^{(f)}$ & $\ldots$ & $\ldots$ & - & 750 & 36.5 & 67.6 & 26.2 & 62.9 \\
\hline
\end{tabular}

(a) Exposures based on manganese -54 .

(b) From McInnes Company reports on samples cut from as-machined $\mathrm{J}-10$ pressure tube.

(c) Metals Handbook, Vol. 1, Eighth Edition, p 503.

(d) Less than $1 \mathrm{mg}$ of sample was submitted for analysis; therefore, the analysis may be inaccurate due to small weighing errors. On the basis of the location of the specimen, a value of $\sim 7 \times 10^{21}$ nvt would be expected.

(e) Only $1.5 \mathrm{mg}$ of sample was analyzed. Small weighing errors could have caused significant errors in analysis. It is believed that the actual value would duplicate $L B-3-1$ since the specimen came from adjacent position.

(f) Samples cut from portion of $\mathrm{J}-10$ pressure tube above reactor core. 
It was observed that the maximum fast-flux exposure to the $\mathrm{J}-10$ pressure tube as determined from manganese-54 analysis occurred in the inner loop and was $7.1 \times 10^{21}$ nvt. The maximum reported neutron flux as noted in Table 14 was about $3.7 \times 10^{14} \mathrm{nv}$, giving a total accumulation of $7.1 \times 10^{21}$ nvt, which compares well with the manganese54 dosimetery data. Other dosimeter samples from test specimens taken from similar tube location gave values of $6.9,6.5,5.1$, and $3.3 \times 10^{21}$ nvt, indicating some circumferential variation of accumulated neutron or scatter in results from the manganese-54 analysis.

\section{Machining of Tensile Test Specimens}

The geometry of the tensile specimens prepared from the loop sections was dictated to a degree by the curvature of the inner and outer core sections. The dimensions ultimately selected for the test specimens are shown in Figure 20. The specimens had an over-all length of $5 \mathrm{in.,}$ a gage section $2.0 \mathrm{in.}$ long by $0.250 \mathrm{in}$. wide, and a shoulder width of 1.12 in. The thicknesses of the tensile specimens were nominally 0.187 and $0.092 \mathrm{in}$. for the inner and outer sections, respectively.

Attempts were made to machine the gage section of the inner loop by means of a 1-in. -diametex end mill cutter attached to a conventional milling machine. This method proved unusable because of the combined effects of radiation hardening and work hardening which made the inner loop material too hard for routine in-cell machining. A cutting tool was constructed to perform this machining task which consisted of an air-driven motor turning a small-diameter carbide-tipped rotary file. A series of cams guided the cutter, which operated at high rotational speeds, to remove approximately 2 to 4 mils of metal from the specimen per pass. The small cutter diameter and its speed of rotation minimized work-hardening effects in the irradiated specimens. Temperature measurements obtained by thermocouples placed a few mils adjacent to the cutter showed a temperature rise of only $30 \mathrm{~F}$ during cutting.

It was noted that specimens machined from the inner loop were considerably harder than those from the outer loop. As many as four changes of cutters were required to machine some of the inner loop specimens. Hardness measurements were also obtained on the shoulders of the tested tensile specimens and are reported elsewhere.

\section{Tensile Testing Experimental Procedure}

Specimens were tested at room temperature (about $75 \mathrm{~F}$ ) and at either 600 or $750 \mathrm{~F}$. Those specimens tested at elevated temperatures were heated in a 3-in.-diameter resistance furnace that enclosed the grip ends of the tester in order to minimize heat losses from the ends. The procedure employed for elevated-temperature tests was to heat the specimen to 600 or $750 \mathrm{~F}$, and maintain this temperature for $30 \mathrm{~min}$ before beginning the test. The temperature was monitored by thermocouples strapped to the center of the gage section of each specimen.

The specimens were tested on a Riehle Model PH 30 tensile tester using a strain rate of 0.005 in. per in. from point of yield to specimen fracture. Crosshead travel was measured by the use of a Riehle Model DC 10 compressometer. 


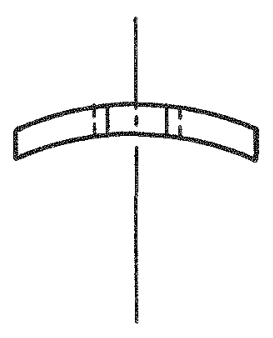

Thickness of specimens from inner loop is $0.187^{\prime \prime}$. Outer loop is $0.092^{\prime \prime}$

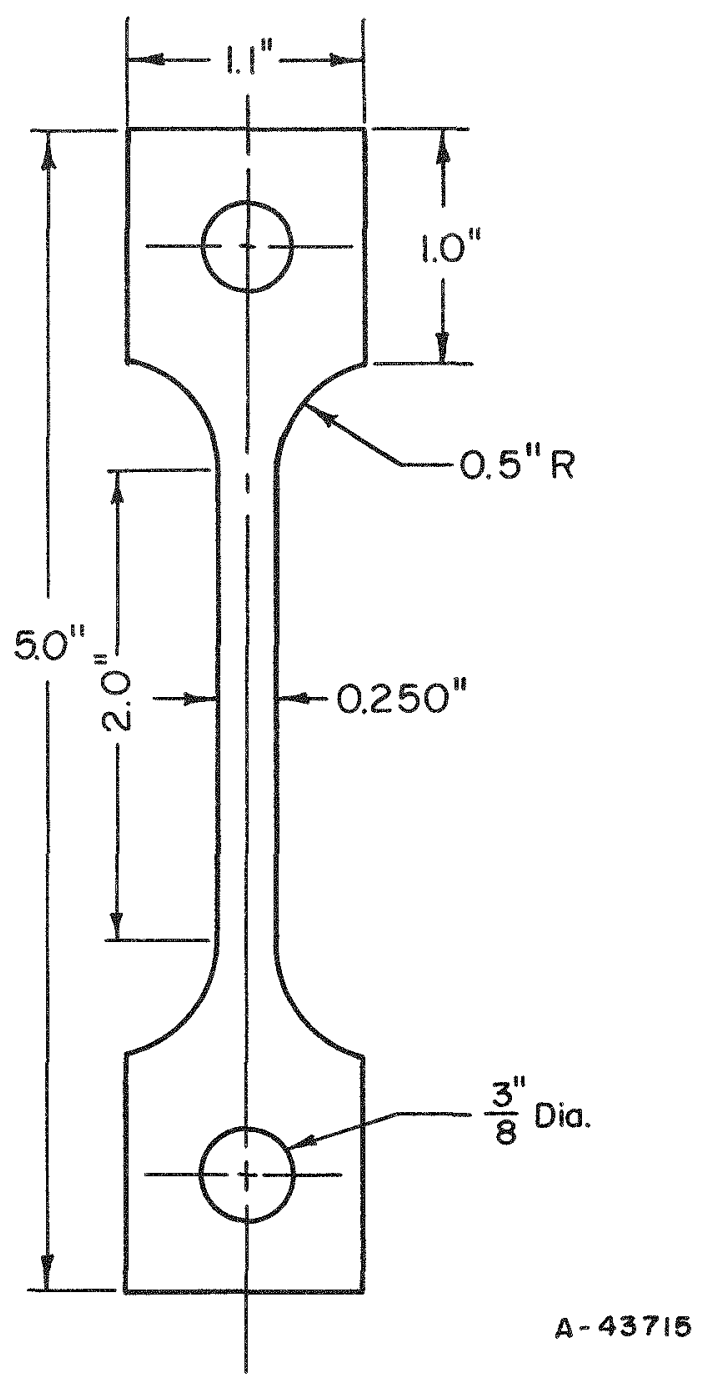

FIGURE 20. CURVED TENSILE SPECIMENS MACHINED FROM J-10 LOOP

Outer loop is $2.265 \mathrm{in}$. in $O D$ and $2.450 \mathrm{in}$. in ID inner loop is 2.200 in. in OD and $1.824 \mathrm{in.}$ in ID. 
The results of the tensile tests on 2 unirradiated Type 347 stainless steel specimens plus 18 irradiated specimens machined from the inner and outer loop sections and tested at room temperature and 600 or $750 \mathrm{~F}$ are given in Table 14. The unirradiated values listed in the table are for comparison and include handbook data, results of tensile tests from specimens machined from an uncontaminated outer loop section, and data from McInnis Steel Company personnel who prepared the inner J-10 pressure tube.

All of the test specimens fractured within the 2-in. gage length and exhibited necking in the area of fracture as shown by photographs of representative specimens (Figures 21 through 23). However, the inner loop specimens gave evidence of reduced ductility as shown by small uniform elongations, a severe reduction in total elongation and decreases in the reduction in area. The maximum changes in room-temperature test properties were observed between samples machined from the midsection of the irradiated inner loop and the control-specimen values (McInnis test results). Increases of about 140 and 60 per cent in 0.2 per cent yield strength and ultimate-strength values, respectively, and decreases of about 90 and 30 per cent in elongation and reduction in area, respectively, were noted. Increases of similar magnitudes were found for the ultimate strength and yield strength for the inner $100 \mathrm{p}$ material at the $750 \mathrm{~F}$ test temperature; however, a further decrease in total elongation, about 90 per cent of the unirradiated values, was observed.

Tests made at room temperature on specimens from the outer jacket indicated that the yield strength and ultimate strength had been increased about 120 and 8 per cent, respectively, over the unirradiated material. The total elongation and the reduction in area were decreased approximately 50 and 12 per cent, respectively. These values compare quite well with those reported by other experiments for Type 347 stainless steel irradiated at $120 \mathrm{~F} .(1)$

The outer jacket material when tested at $750 \mathrm{~F}$ showed about the same degree of increase in the ultimate strength, a slightly less increase in yield strength, and further decrease in total elongation and reduction in area as compared with unirradiated specimens. The decrease in total-elongation values as function of increasing test temperature to about $900 \mathrm{~F}$ is characteristic of unirradiated stainless steel and should not be considered a result of irradiation. However, the extreme difference between the results from the inner loop and outer jacket (much greater) at similar levels of exposure at the same test temperature does appear to be the result of irradiation under stress and/or temperature. The shape of the stress-strain curves for the inner loop and the outer jacket was entirely different. In the case of the inner loop, the maximum load occurred at approximately 0.5 to 0.75 per cent elongation. The outer jacket showed elongation greater than 40 per cent at maximum load. Unfortunately unirradiated material exposed to a similar stress and thermal history was not available. The influence of tube fabrication and heat-treatment history are also indeterminable.

Metallography and Hardness Testing

Metallographic examinations were performed upon several irradiated sections of the J-10 loop. These examinations included a section of the outer loop and eight irradiated sections of the inner loop. The inner loop sections covered a range of exposures from about $2.0 \times 10^{21}$ to $7.1 \times 10^{22} \mathrm{nvt}$. Photomicrographs of the preirradiation 

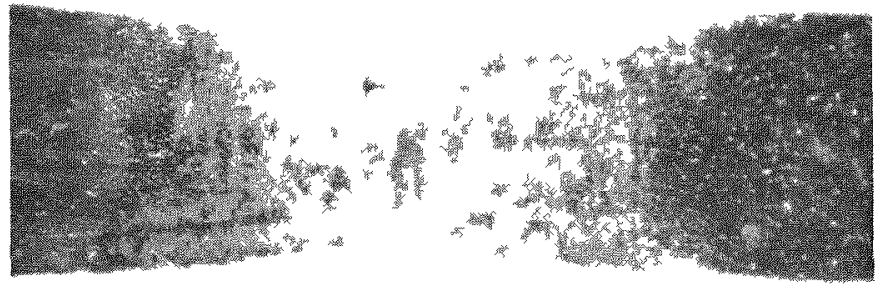

$4 \mathrm{X}$

HC800?
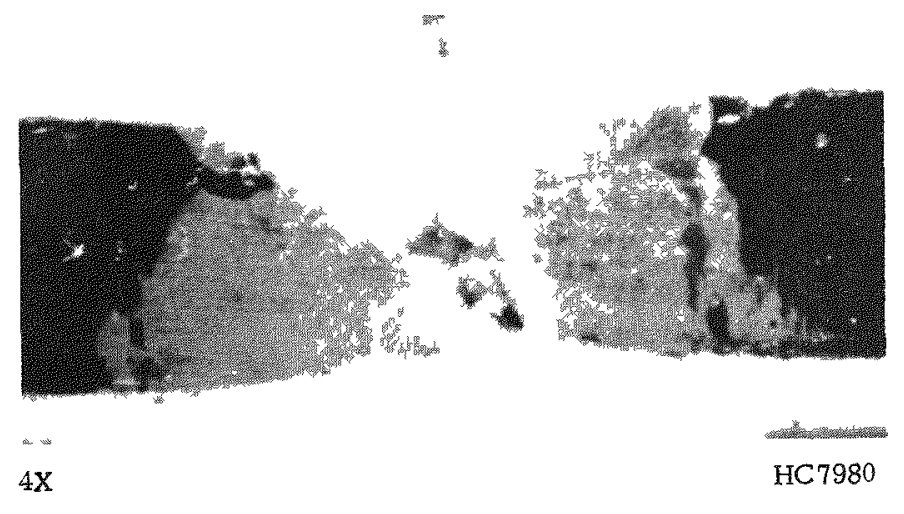

HC 7980 a. Specumen ST $-3-\mathrm{L}\left(1.9 \times 10^{21} \mathrm{NVT}\right)$ after Testing at $75 \mathrm{E}$ b. Specimen ST-2-H $\left(7.1 \times 10^{21}\right.$ NVT $)$ after Testing at $75 \mathrm{~F}$

Black material is dye marker.

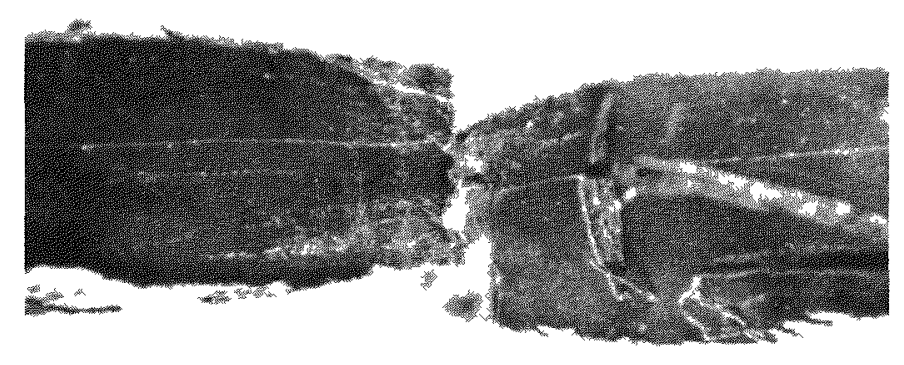

c. Specimen ST-2-L (2.1 $\left.\times 10^{21} \mathrm{NVT}\right)$ after Testing at $750 \mathrm{~F}$

$4 \mathrm{X}$

HC8000

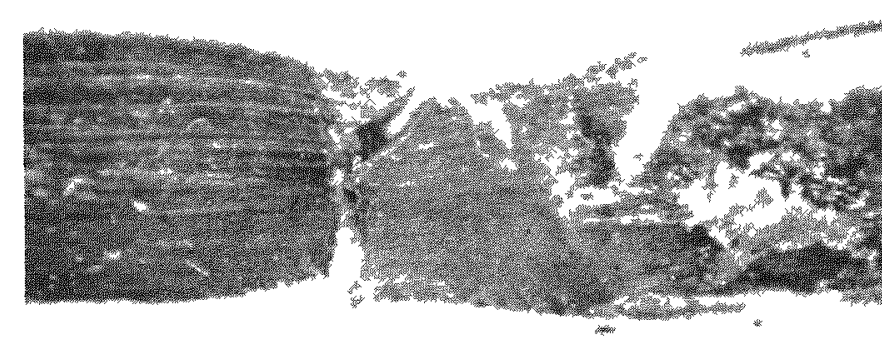

d. Specimen SB-2-H $\left(6.9 \times 10^{21} \mathrm{NVT}\right)$ after Testung at $750 \mathrm{~F}$

FIGURE 21. INNER LOOP TEST SPECIMENS AFTER TENSILE TESTING

All specimens showed necking at fracture. The area of the loop from which these specimens were machined operated at temperatures as high as $750 \mathrm{~F}$. 


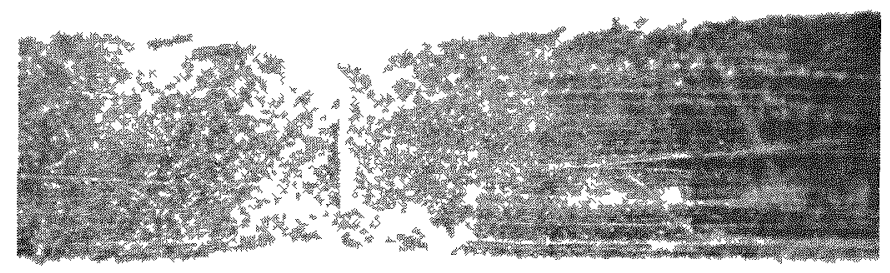

a. Specimen $L T-4-\mathrm{L}\left(1.8 \times 10^{21} \mathrm{NVT}\right)$ after Testing at 75

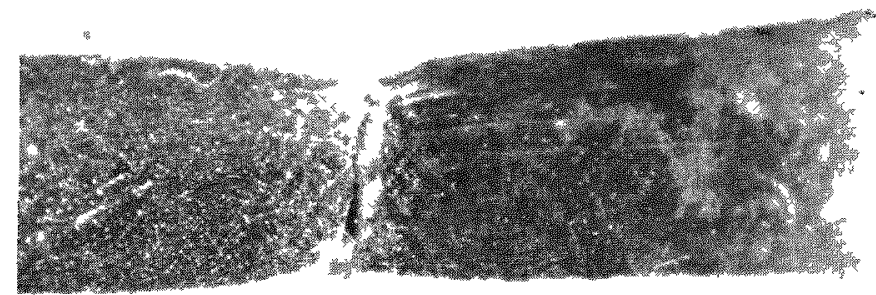

b. Specimen LT-3-L $\left(2.0 \times 10^{21} \mathrm{NVT}\right)$ after Testing at $750 \mathrm{~F}$

$4 \mathrm{X}$

HC8021

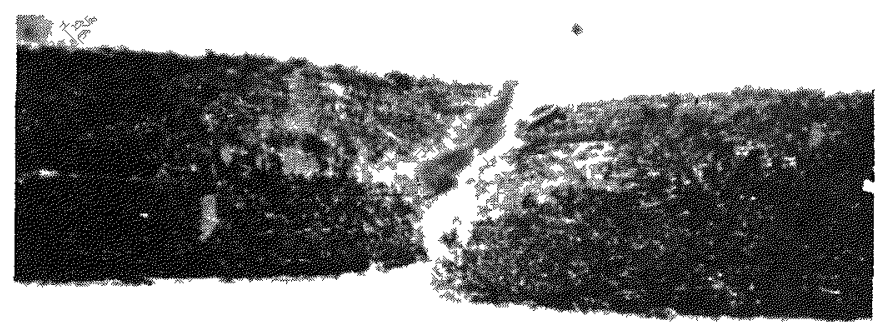

c. Speciman LB-3-H $\left(6.5 \times 10^{21} \mathrm{NVT}\right)$ after Testing at $75 \mathrm{~F}$

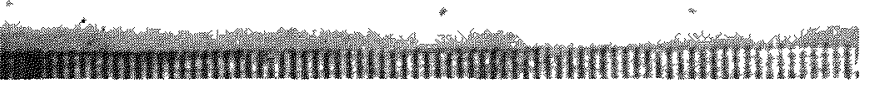

$4 \mathrm{X}$

HC7993

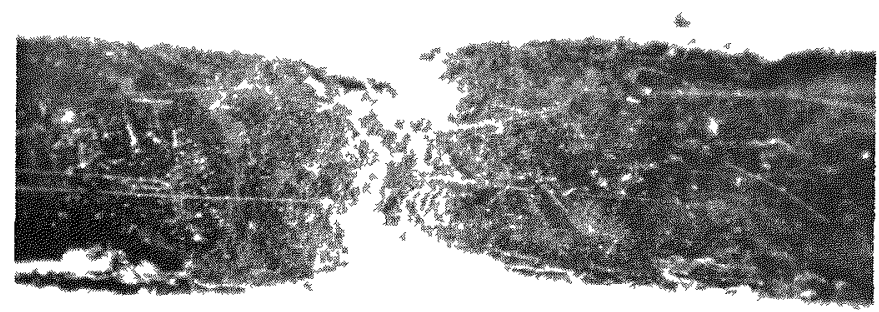

d. Specimen $\mathrm{LT}-3 \mathrm{H}\left(5.1 \times 10^{21} \mathrm{NVT}\right)$ after T esting at $600 \mathrm{~F}$

$4 X$

HC7975

EIGURE 22. OUTER LOOP TEST SPECIMENS AFTER TENSILE TESTING

This part of the loop was maintained at process-water temperature during irradiation. 


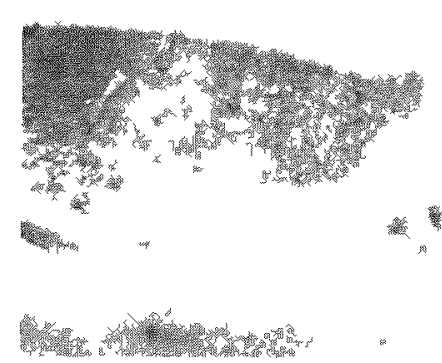

$4 X$

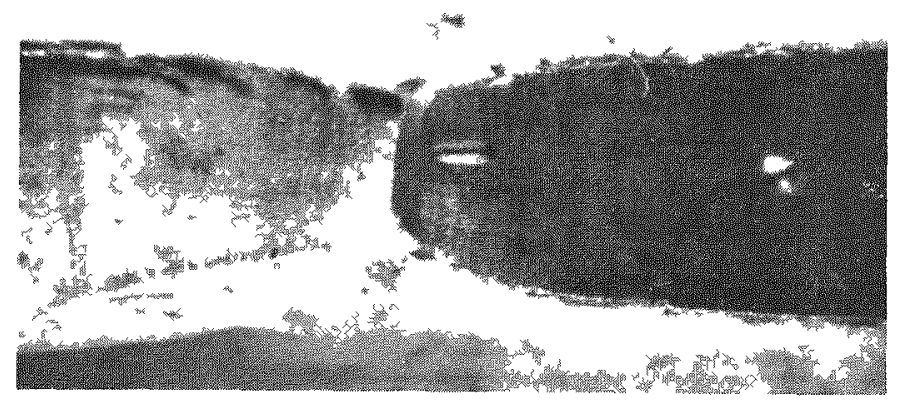

$4 X$

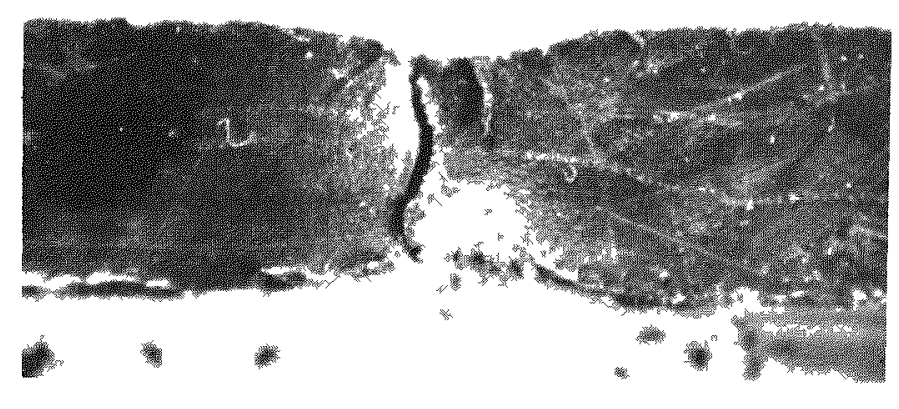

$4 \mathrm{X}$

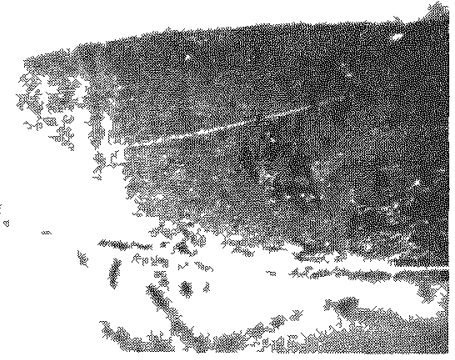

HC10075

HC10069

a. Specimen ST-7-L $\left(1.7 \times 10^{21}\right.$ NVT $)$ after Testing at $75 \mathrm{~F}$

b. Specimen ST $-7-\mathrm{H}\left(\sim 3.26 \times 10^{21} \mathrm{NVT}\right)$ after Testing at $75 \mathrm{~F}$

Note elongated hardness mpression in reduced area. The exposure value is uncertain. On the basis of the specimen location a value of $\sim 7 \times 10^{21}$ NVT would be expected. See Table $14_{\text {q }}$

c. Specimen SB-7-L. $\left(2.3 \times 10^{21}\right.$ NVT $)$ after Testing at $750 \mathrm{~F}$

HC10090

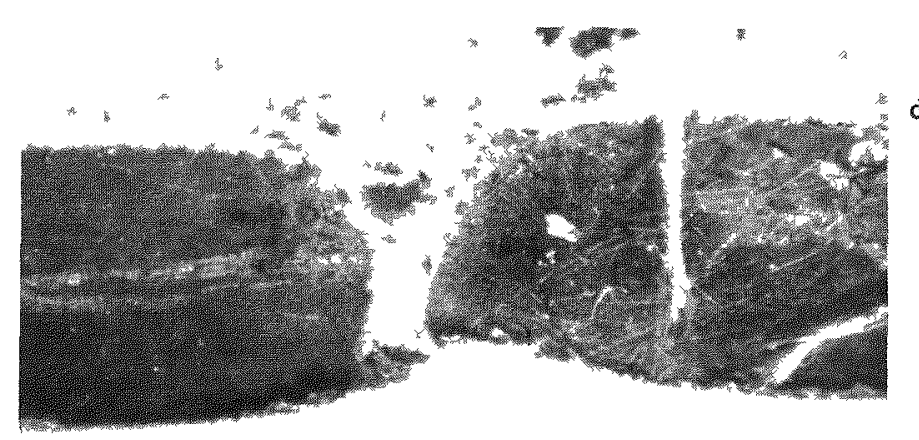

d. Specimen $\mathrm{SB}-7-\mathrm{H}\left(6.5 \times 10^{21} \mathrm{NVT}\right)$ after Testing at $750 \mathrm{~F}$ 
microstructures of the inner and outer loops were available for comparison with the irradiated specimens. The metallographic examinations were carried out on the shoulders of the tensile specimens. These sections were mounted in Bakelite, and ground through 240-, 400-, and 600-grit silicon carbide paper. Polishing was accomplished on vibrators containing $1-\mu$ alumina, Linde $\mathrm{A}$, and Linde $\mathrm{B}$ abrasives. The specimens were examined in the polished condition, and after treating with a 10 per cent oxalic acid electroetch or a glyceregia swab etch.

The microstructures of samples of the outer J-10 gas jacket are shown in Figure 24. The most outstanding feature of the outer loop is the duplex grain size, which was present in both the unirradiated control material and irradiated material (Specimen LB $-3-H$ ). The nonuniformity of the duplex grain size in this material appeared to be a function of fabrication and heat treatment and a direct comparison could not be made. But after viewing a number of samples the general impression was that irradiation had not altered the microstructure.

Microstructures of samples from the inner loop or pressure tube are shown in Figure 25. Except for a slight darkening of inclusions in the irradiated samples, there was no microstructural difference between the control specimen and the irradiated specimens. Both inner and outer surfaces of the loop were in excellent condition, with no visible cracks, corrosion, or other defects present.

Hardness values were obtained on the grip ends and gage section of irradiated tensile specimens from the inner pressure loop. Readings of 101 to 106 Rockwell B were obtained upon these specimens after testing and showed only slight variation in values as a function of exposure.

Hardnesses were also obtained on unirradiated control specimens and irradiated test specimens from the outer jacket of the J-10 loop. The average room-temperature hardness value for the unirradiated control specimens was 87 Rockwell $B$. The roomtemperature hardness of irradiated outer jacket specimens tested at $75 \mathrm{~F}$ was 100 Rockwell $B$. The hardness of specimens tested at 600 and $750 \mathrm{~F}$ ranged from 91 to 97 Rockwell B. Thus, it was observed that the inner loop specimens were harder than the outer jacket specimens, which were in turn harder than the unirradiated outer jacket specimens.

Since the preirradiation values were not available, no comparis on could be made between preirradiation and postirradiation hardness values for the inner 10op. The changes observed in the outer jacket were typical for stainless steel for these levels of irradiation.

\section{Discussion and Conclusions}

The examination of the $J-10$ loop was of considerable value, since the data revealed the mechanical-property changes which occurred in a structural material under actual operating conditions of pressure, temperature, and neutron flux. Irradiation of encapsulated specimens can never duplicate in situ irradiations of reactor components since the specimens are not subjected to variations in temperature and stress, two parameters which may contribute to property changes in irradiated structures. 


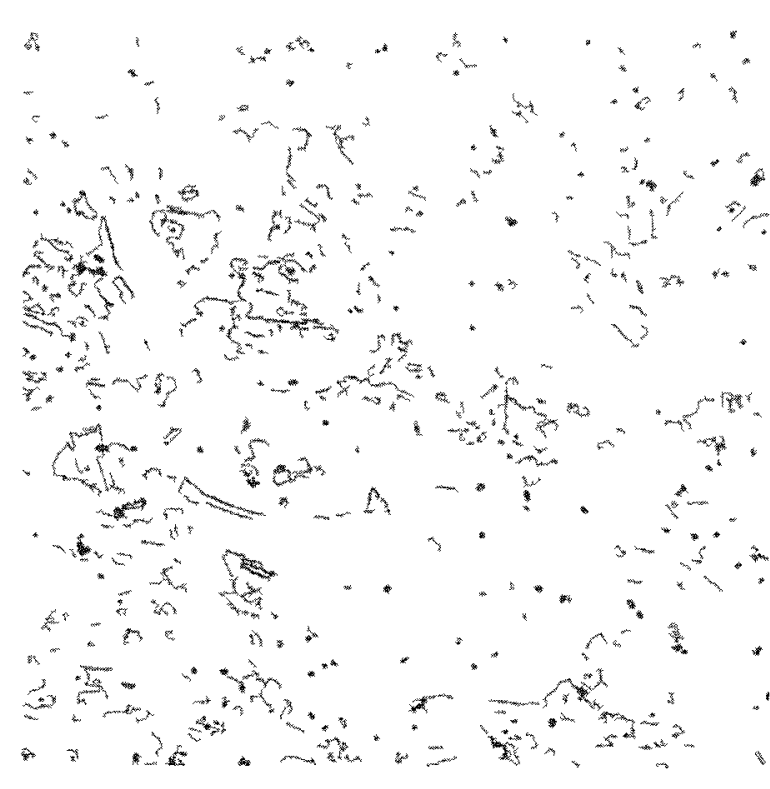

$100 \mathrm{X}$

Etched

N2974A

a. Unurradiated Control Specimen (WAPD Photomicrograph)

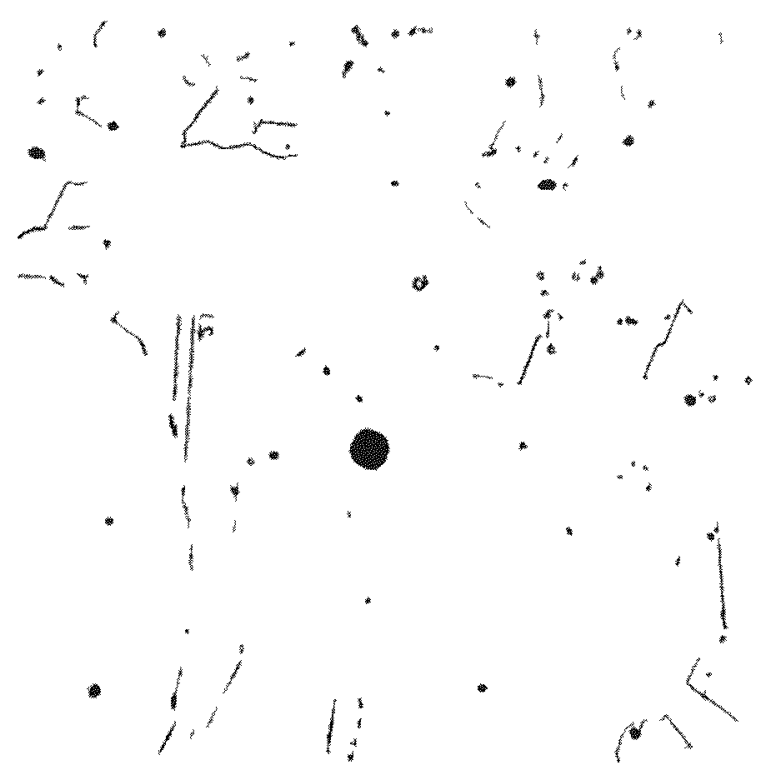

$250 \mathrm{X}$

Etched

HC 9041

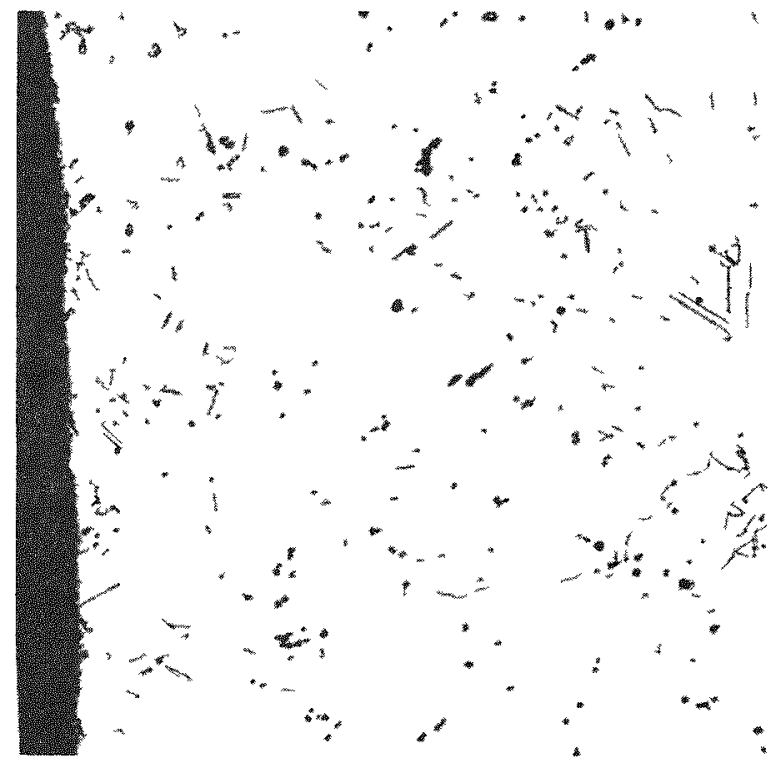

$125 \mathrm{X}$

HC9035 b. Inside Edge of Specimen LB-3-I Irradiated at $120 \mathrm{~F}$ ro $4.5 \times 10^{21} \mathrm{NVT}$

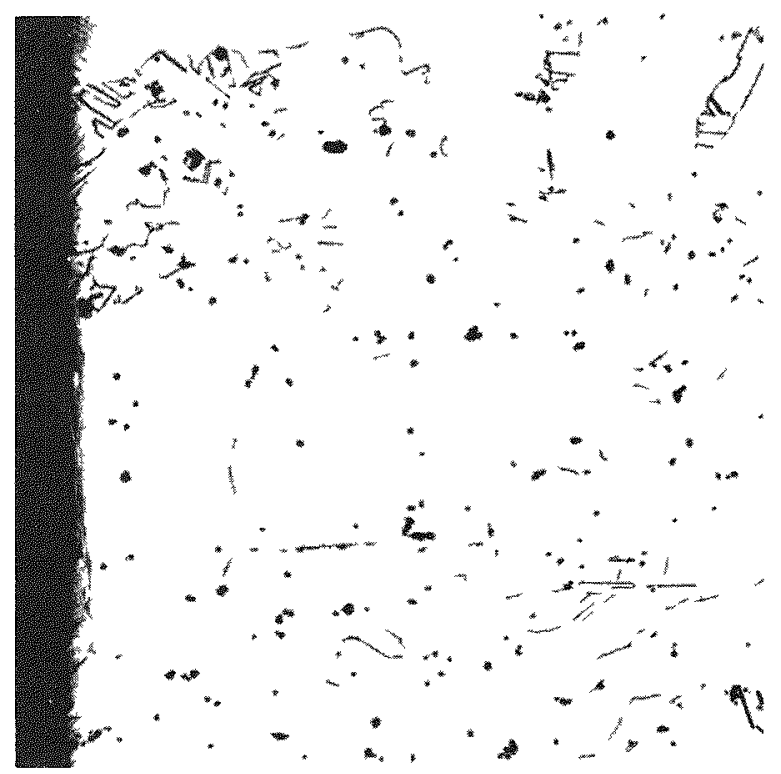

$125 X$

Etched

HC9037

c. Center of Specimen $\mathrm{LB}-3-\mathrm{H}$ Irradiated at $120 \mathrm{~F}$ to $6.5 \times 10^{21} \mathrm{NVT}$

d. Outside Edge of Specimen LB-3-H

FIGURE 24. AN UNIRRADIATED CONTROL AND TWO IRRADIATED SPECIMENS FROM THE OUTER JACKET OF THE J-10 LOOP EXHIBITING DUPLEX GRAIN STRUCTURE

No change in the microstructure as a result of the irradiation was observed. 


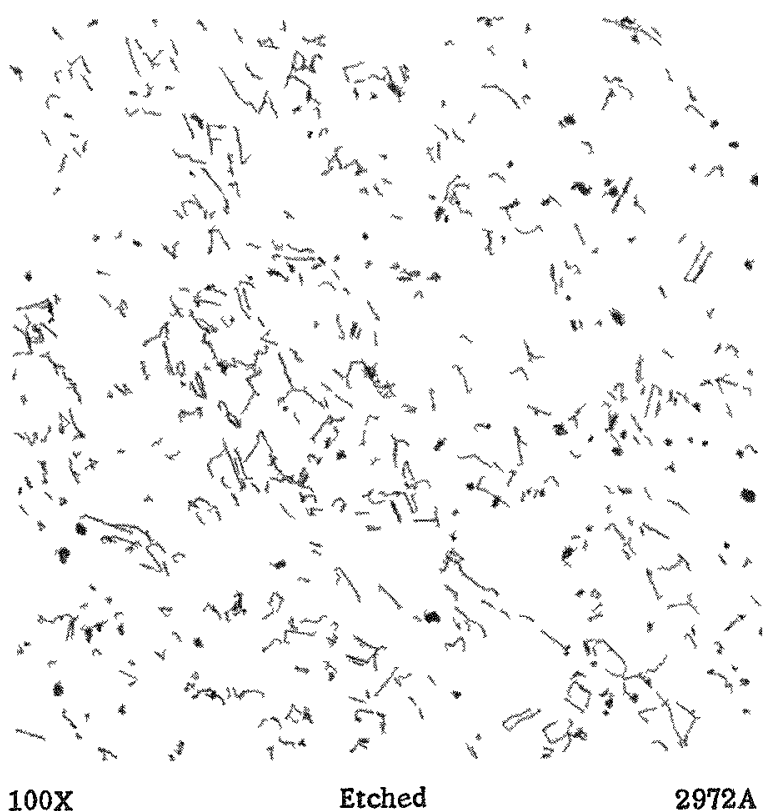

a. Unirradiated Control Specimen

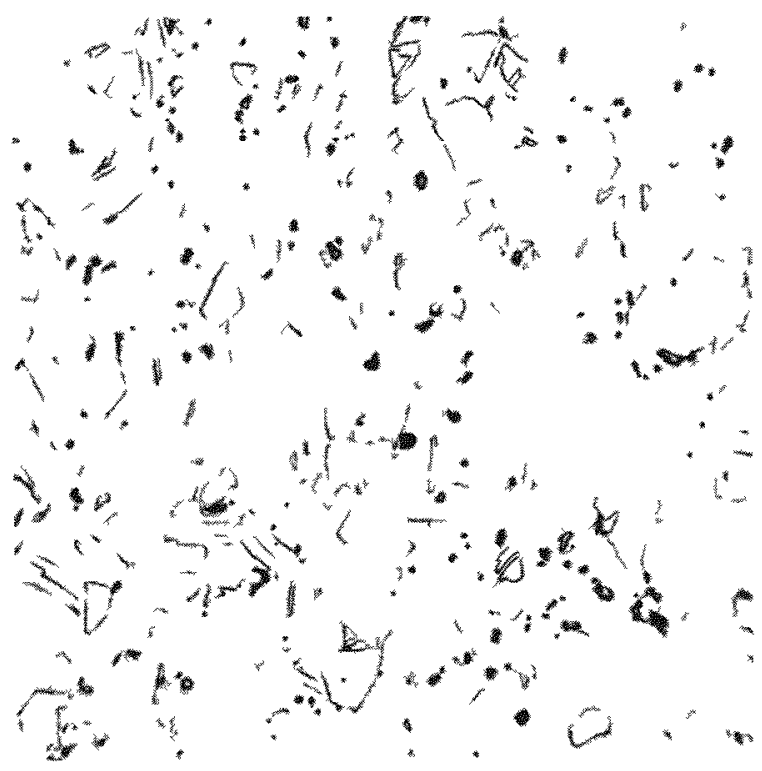

$125 \mathrm{X}$
Etched

HC9050

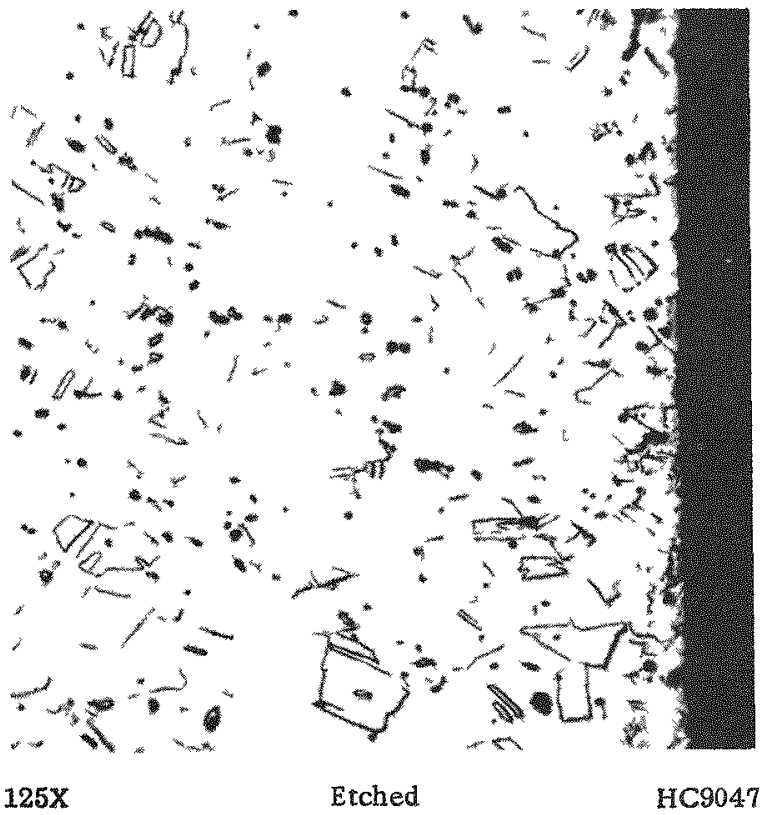

b. Inside Edge of Irradiated Specimen ST-2-H

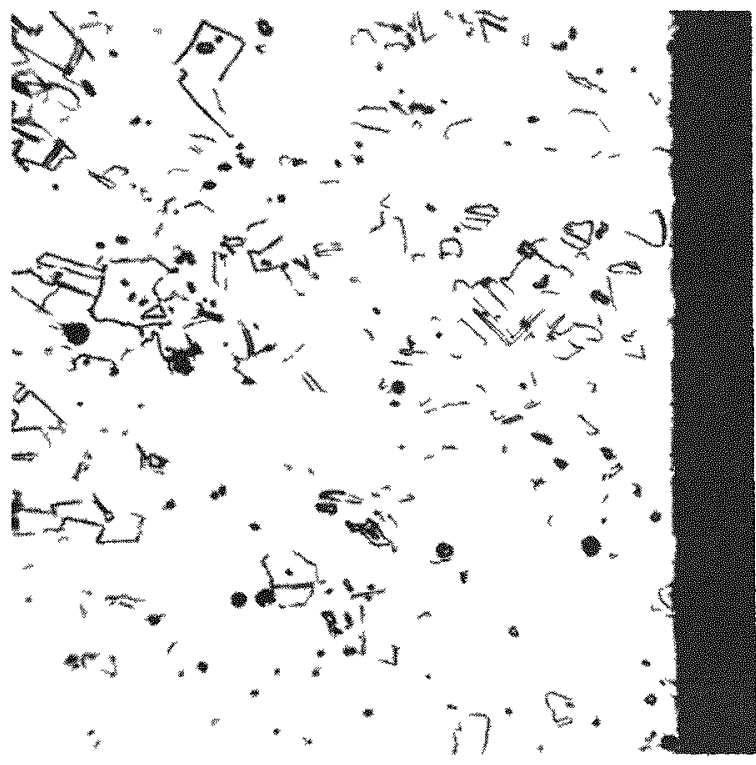

$125 \mathrm{X}$

Etched

HC9049

c. Center of Specimen ST-2-H

d. Outside Edge of Specimen ST-2-H

FIGURE 25. MICROSTRUCTURES OF UNIRRADIATED CONTROL SPECIMEN AND SPECIMEN ST -2-H FROM THE INNER LOOP AFTER IRRADIATION AT 780 F TO $7.1 \times 10^{21} \mathrm{NVT}$

Except for darker inclusions in the irradiated specimen, there were no dufferences evident in the microstructures. 
The results obtained during tests of the $\mathrm{J}-10$ pressure tube sections were somewhat surprising in that the inner loop displayed a greater magnitude of changes in properties than was anticipated. Since this loop operated near $750 \mathrm{~F}$, it was believed that the accumulated effects of irradiation would have been reduced by annealing at the temperature of irradiation. These effects, however, were expected to have been retained in the outer, lower temperature jacket. Postirradiation tests showed that the inner loop sustained greater changes in yield and ultimate strengths as well as a greater loss in ductility than the outer jacket. The test results for outer jacket specimens were generally comparable with results obtained on Type 347 stainless steel by other investigators. $(1-4)$ The tests on both inner and outer loop materials show evidence of increased property changes with additional neutron exposure. This change in properties with additional neutron exposure was not entirely compatible with results of the encapsulated specimen tests (BMI-24 series) discussed earlier, which showed a saturation of irradiation effects on yield and ultimate strengths and hardness at an exposure of about $6.5 \mathrm{x}$ $10^{21}$ nvt. At the same time, metallographic evidence indicated that there was no obvious change in microstructure of either the loop or encapsulated specimens as a result of ir radiation.

The data from the J-10 loop indicate that the stress state and irradiation temperature may play a very important role in property changes during irradiation. They also serve to illustrate the extreme importance of ascertaining the complete composition, fabrication history, heat-treatment history, and thermal history of the material before irradiation. One can never know too much about the material under study in programs of this type. In summary, the greater changes observed may have resulted from any one or all of a number of variables among which are material fabrication, material composition, stress state during irradiation, and temperature during irradiation.

The observed differences between properties of encapsulated and of loop specimens, and in particular the property differences of material subjected to elevated-temperature loop irradiation, should be resolved. One method of resolution might be to irradiate and examine fully annealed test loops under conditions of temperature, pressure, and exposure similar to those sustained by the J-10 loop. An alternate method would be to ir radiate at elevated temperature and examine test specimens of Type 347 stainless steel of various fabrication histories.

\section{REFER ENCES}

(1) Graber, M. J., and Ronsick, J. H., "ETR Radiation Damage Surveillance Programs Progress Report I" IDO-16628 (January 27, 1961).

(2) Leeser, D. O., Manual 107, Materials \& Methods (August, 1954).

(3) Murphy, W. F., and Payne, S. H., "Fast Neutron Effects on Tensile and Hardness Properties of Type 347 Stainless Steel", Symposium on Radiation Effects on Materials, ASTM, Vol. I, p 162 (1956). 
(4) Bartz, M. H., "Performance of Metals During Six Years Service in the Materials Testing Reactor", Proceedings of the Second United Nations Internations Conference on the Peaceful Uses of Atomic Energy, Geneva (1958), A/CONF.15/P/1878, Vol. 5, pp 466-74.

(5) Roy, J. C., and Hawton, J. J., "Tables of Estimated Cross Section for $(n, p),(n, \alpha)$, and $(n, 2 n)$ Reactions in a Fission Neutron Spectrum", CRC-1003 (December, 1960).

(6) Porter, L. F., U. S. Steel Company, Unpublished Data.

(7) Tavernelli, J. F., and Coffin, L. E., Jr., "A Compilation and Interpretation of Cyclic Strain Fatigue Tests on Metals", Trans. ASM, 51, 438 (1959).

(8) Reynolds, M. B., Low, J. R., Jr., and Sullivan, L. O., "Study of the Radiation Stability of Austenitic Type 347 Stainless Steel." AIME Trans., 203, 555 (1955).

(9) Letter to Mx. H. N. Hughes from M. Dumas dated August 15, 1961, WAPD-M (IPC)2522.

WEM:FRS:RL:RFD/dnm 